UNIVERSIDADE DE SÃO PAULO

FACULDADE DE FILOSOFIA, LETRAS E CIÊNCIAS HUMANAS

DEPARTAMENTO DE SOCIOLOGIA

Ian Prates Cordeiro Andrade

ESTRUTURA OCUCPACIONAL E POBREZA NA REGIÃO

METROPOLITANA DE SÃO PAULO, 1991-2010

(Versão corrigida)

São Paulo

2013 
UNIVERSIDADE DE SÃO PAULO

FACULDADE DE FILOSOFIA, LETRAS E CIÊNCIAS HUMANAS

DEPARTAMENTO DE SOCIOLOGIA

\section{ESTRUTURA OCUCPACIONAL E POBREZA NA REGIÃO}

METROPOLITANA DE SÃO PAULO, 1991-2010

Ian Prates Cordeiro Andrade

Dissertação apresentada ao Departamento de Sociologia da Faculdade de Filosofia, Letras e Ciências Humanas da Universidade de São Paulo para obtenção do título de Mestre em Sociologia

Orientadora: $\operatorname{Prof}^{\mathrm{a}} \mathrm{Dr}^{\mathrm{a}}$. Nadya Araújo Guimarães

Versão corrigida.

De acordo,

São Paulo 
Ian Prates Cordeiro Andrade

\title{
ESTRUTURA OCUCPACIONAL E POBREZA NA REGIÃO METROPOLITANA DE SÃO PAULO, 1991-2010
}

\begin{abstract}
Dissertação apresentada ao Departamento de Sociologia da Faculdade de Filosofia, Letras e Ciências Humanas da Universidade de São Paulo para obtenção do título de Mestre em Sociologia
\end{abstract}

Aprovada em:

Banca Examinadora:

Prof $^{\mathrm{a}} \mathrm{Dr}^{\mathrm{a}}$. Nádya Araújo Guimarães (presidente) Instituição: FFLCH/USP Julgamento: Assinatura

Prof ${ }^{a}$ Dr. Adalberto Moreira Cardoso Instituição: IESP/UERJ

Julgamento: Assinatura

Prof $^{a}$ Dr. Eduardo César Leão Marques Instituição: FFLCH/USP

Julgamento: Assinatura 
À Lili, minha irmã. 


\section{AGRADECIMENTOS}

São inúmeras as pessoas e as instituições a agradecer. Como estas últimas são mais fáceis de lembrar, começo por elas.

Agradeço ao CNPq que me agraciou com a bolsa de Mestrado nos primeiros doze meses dessa trajetória. À Fapesp (Processo 2011/04923-0) e aos pareceristas ad hoc que aceitaram o pedido de reconsideração e me concederam a bolsa ao longo do segundo ano.

Ao Programa de Pós Graduação em Sociologia e ao Departamento de Sociologia da Universidade de São Paulo.

À Pró Reitoria de Pós Graduação da USP, que me concedeu o financiamento para participar no $24^{\circ}$ Encontro Anual da Society for the Advancement of Socio-Economics.

Ao Centro de Estudos da Metrópole e ao Centro Brasileiro de Análise e Planejamento.

Aos departamentos de Sociologia e Antropologia e de Ciência Política da UFMG, e vários dos professores que ali estão, onde cursei a graduação em Ciências Sociais e que muito do aprendido carrego comigo.

Ao Departamento do Cadastro Único do Ministério do Desenvolvimento Social e Combate à Fome do Governo Federal, em especial na pessoa da Sra. Fernanda Pereira de Paula, pela concessão dos dados do CadÚnico.

Ao Cruzeiro, que é muito mais que uma instituição...

Passando às pessoas...

Agradeço à Prof ${ }^{a}$ Nadya Guimarães, pela calorosa acolhida desde os tempos de seleção ao mestrado e, posteriormente, pela dedicação, cuidado e paciência no seu trabalho de orientação. E também pelo convite a integrar sua equipe de pesquisa no CEM/Cebrap. A ela o meu mais sincero "Obrigado".

Ao Prof. Eduardo Marques, do DCP/USP, que leu e comentou uma primeira versão do projeto e, posteriormente participou da banca de qualificação e aceitou participar da 
banca de defesa. Agradeço também por ter me convidado a integrar a equipe do Projeto "São Paulo nos 2000", onde tive a oportunidade de apresentar resultados primários desta pesquisa e muitas das criticas ali recebidas foram incorporadas.

À Prof ${ }^{a}$ Marta Arretche, nossa "chefe" no "Projeto Censo".

À Prof ${ }^{a}$ Vera Telles, que também participou da banca de qualificação e que muito contribuiu para o rumo que a pesquisa tomou.

Ao Prof. Adalberto Cardoso, por aceitar participar da banca de defesa e pela disponibilização do manuscrito do seu ultimo livro, do qual muito me beneficiei.

Aos colegas do "Grupo de Apoio Metodológico" do "Projeto Censo" no CEM, com quem muito aprendi e sem a ajuda dos quais o tratamento dos dados que aqui apresento não teria sido o mesmo: Murillo de Brito, Patrick Silva, Leonardo Barone e Diogo Ferrari. Ao Rogério Jerônimo Barbosa um agradecimento especial, pela ajuda no tratamento e sistematização dos dados que fundamentam o estudo empírico desta dissertação. E, mais do que isso, por toda a sorte de contribuição e disposição em ajudar por todo o tempo.

Agradeço aos colegas da Oficina de Sociologia Econômica e do Trabalho, coordenada pela Prof ${ }^{a}$ Nadya Guimarães, que leram alguns dos desenvolvimentos dessa pesquisa ao longo desses dois anos e teceram importantes comentários, dos quais muitos foram incorporados aqui: Além de Murillo e Rogério, a quem já me referi, agradeço à Jonas Bicev, Jaime Santos Junior, Ana Carolina Andrada, Monise Picanço, Lucas Azambuja, Priscila Vieira, André Nahoum e Flávio Carvalhaes.

Ao Alexandre Barbosa, Renata Bichir e Paula Montagner, convidados dessa oficina em diferentes momentos, que leram atentamente versões preliminares dos capítulos e forneceram importantes contribuições.

Agradeço ao Prof. Antonio Augusto Pereira Prates, do Departamento de Sociologia e Antropologia da UFMG, pelo incentivo e exemplo, desde os tempos da graduação. E à Prof $^{a}$ Carla Bronzo, da Escola de Governo da Fundação João Pinheiro, fonte de inspiração e quem primeiro "me acolheu" ainda nos primeiros anos da graduação.

À Cris e à Erica, que me receberam quando aqui cheguei. 
À minha prima Beta, que se tornou uma irmã, e aos meus tios Zé e Joaquina, única parte da família aqui em São Paulo. Um obrigado especial ao três.

Aos amigos de São Paulo que se tornaram grandes companheiros. Rafael de Souza, Lucas Amaral, Luiz Caseiro, Andréa Roca. Especialmente ao Leonardo Melo Lins, colega de casa, parceiro de inúmeras e (in) frutíferas discussões (de Cruzeiro x Atlético à Parsons). Sem a sua companhia diária esta dissertação certamente teria outro rumo. Ao Victor, que chegou faz pouco tempo e integrou a colônia mineira no Butantã.

A todos os amigos de Belo Horizonte e da coorte 2005/1 do Curso de Ciencias Sociais da UFMG.

A João, Renato e Ana Luiza, como sempre e pelo sempre.

À Chica, minha prima, por tudo...

Especialmente, e sem muito precisar dizer: à minha mãe, Ana, ao meu pai, Oswaldo, e à minha irmã, Elisa.

E claro, à Lolinha, pelo companheirismo e carinho, motivo maior das inúmeras viagens a Belo Horizonte ao longo desses dois anos e meio. De quem senti mais falta desde que aqui cheguei, mas de quem tenho certeza que estarei mais perto nos próximos passos, que daremos juntos. 
O melhor será que se vão numerando e dizendo cada um quem é. Parados, os cegos hesitaram, mas alguém tinha de principiar, dois dos homens falaram simultaneamente, sempre acontece, os dois se calaram, e foi o terceiro quem começou, Um, fez uma pausa, parecia que ia a dizer o nome, mas o que disse foi. Sou polícia. e a mulher do médico pensou, Não disse como se chama, também saberá que aqui não tem importância. Já outro homem se apresentava, Dois, e seguiu o exemplo do primeiro, Sou motorista de táxi. O terceiro homem disse, Três, sou ajudante de farmácia. Depois, uma mulher, Quatro, sou criada de hotel, e a última, Cinco, sou empregada de escritório. (JOSÉ SARAMAGO) 


\section{RESUMO}

PRATES, I. Estrutura ocupacional e pobreza na Região Metropolitana de São Paulo. 2013. 152f. Dissertação (Mestrado) - Faculdade de Filosofia, Letras e Ciências Humanas, Universidade de São Paulo, São Paulo, 2013

No Brasil, o fenômeno da pobreza foi interpretado, mais das vezes, a partir da sua relação com o mercado de trabalho, com a escassez da proteção social e com o processo de expansão do assalariamento. Por outro lado, os estudos sobre estrutura ocupacional raras vezes adotam a pobreza como fenômeno a ser analisado, relegando-a a um mero subproduto das dinâmicas da estratificação social. Esta pesquisa pretende mostrar como podemos incorporar a estrutura ocupacional, a partir da sua relação com as mudanças econômicas e a proteção social, à análise da pobreza. Utilizamos como estudo de caso a Região Metropolitana de São Paulo, observada no período compreendido entre os anos de 1991 e 2010, quando analisamos, à luz de dados censitários, como diferentes padrões da estrutura ocupacional nessas duas décadas condicionaram a dinâmica da pobreza.

Palavras-chave: Estrutura ocupacional; pobreza; proteção social; mercado de trabalho; Região Metropolitana de São Paulo. 


\begin{abstract}
PRATES, I. Occupational structure and poverty in the Metropolitan Area of São Paulo. 2013. 152f. Dissertação (Mestrado) - Faculdade de Filosofia, Letras e Ciências Humanas, Universidade de São Paulo, São Paulo, 2013.

In Brazil, poverty has been interpreted, in most cases, from its relations with the labor market, the tight scope of social protection and the process of the expansion of the paid labor force. In the other hand, the studies about occupational structure don't use to embrace poverty as a phenomenon to be analyzed. Usually, poverty is seemed as a residue of the social stratification dynamics. This research aims to show how we can incorporate the occupational structure and its relationship with the economic changes and social protection, to analyze poverty. We use the Metropolitan Area of São Paulo between the years of 1991 and 2010 as a case study; based on census data we analyze how different patterns of occupational structure in these two decades constrained the dynamics of poverty.
\end{abstract}

Keywords: Occupational Structure; poverty; social protection; labor market; Metropolitan Area of São Paulo 


\section{LISTA DE GRÁFICOS}

Gráfico 1 - Indicadores de pobreza e mercado de trabalho na RMSP, 1991-2010 ..... 23

Gráfico 2 - Participação relativa dos setores de atividades econômicas (ISIC) no volume total de empregos, RMSP; 1991-2010

Gráfico 3 - Total de empregos gerados nos subsetores de "Serviços", RMSP; 1991-2010

Gráfico 4 - Participação relativa dos setores de atividade econômica no saldo de empregos criados, RMSP; 1991-2010.

Gráfico 5 - Gráfico de Variação da Renda do trabalho nos subsetores de serviços, RMSP; 1991-2010......

Gráfico 6 - Quatro diferentes situações hipotéticas num cenário de criação de 1 milhão de empregos

Gráfico 7 - Evolução da estrutura ocupacional: saldo dos quintis de ocupação RMSP, 1991-2000...........

Gráfico 8 - Evolução da estrutura ocupacional: saldo dos quintis de ocupação, RMSP; 2000-2010.....

Gráfico 9 - Distribuição dos estratos educacionais, segundo os quintis de ocupação, RMSP; 1991

Gráfico 10 - Distribuição dos estratos educacionais, segundo os quintis de ocupação, RMSP; 2000

Gráfico 11 - Saldo de ocupados e desocupados, segundo quintis de ocupação e controlando pela escolaridade, RMSP; 1991-2000.....

Gráfico 12 - Saldo de ocupados, segundo quintis de ocupação e controlando por setores de atividades econômicas, RMSP; 1991-2000.

Gráfico 13 - Saldo de ocupados, segundo quintis de ocupação e controlando por subsetores do setor de serviços, RMSP; 1991-2000

Gráfico 14 - Distribuição dos estratos educacionais, segundos os quintis de ocupação, RMSP; 2000

Gráfico 15 - Distribuição dos estratos educacionais, segundos quintis de ocupação, RMSP; 2010

Gráfico 16 - Saldo de ocupados e desocupados, segundo quintis de ocupação e controlando pela escolaridade, RMSO; 2000-2010 
Gráfico 17 - Evolução da estrutura educacional, segundo saldo dos quintis e grandes setores de atividades econômica, RMSP; 2000-2010

Gráfico 18 - Evolução da estrutura educacional, segundo saldo dos quintis (apenas subsetores dos serviços), RMSO; 2000-2010

Gráfico 19 - Saldo de ocupados, segundo quintis de ocupação e controlando por formalização, RMSP; 1991-2000.

Gráfico 20 - Saldo de ocupados, segundo quintis de ocupação e controlando por formalização, RMSP; 2000-2010.

Gráfico 21 - Indicadores do mercado de trabalho para indivíduos "pobres" e

"vulneráveis", RMSP; 1991-2010

Gráfico 22 - Evolução da estrutura ocupacional segundo estratos de renda domiciliar per capita, RMSP; 1991-2010.

Gráfico 23 - Evolução da estrutura ocupacional, segundo saldo dos quintis e estratos de renda domiciliar per capita, RMSP; 1991-2010.

Gráfico 24 - Evolução da estrutura ocupacional; 1991-2000 e 2000-2010: Exercícios originais e contrafactuais. 


\section{LISTA DE TABELAS}

Tabela 1 - Estrutura salarial da RMSP, 1991-2010

Tabela 2 - Rendimentos médios absolutos e relativos nos subsetores dos serviços,

RMSP; 1991-2010 86

Tabela 3 - Indicadores do mercado de trabalho por escolaridade, RMSP; 1991-2010 .. 89

Tabela 4 - Distribuição dos quintis de ocupação e renda média: 1991, 2000 e 2010..... 97

Tabela 5 - Principais ocupações dos quintis e renda média, 1991, 2000 e 2010 98

Tabela 6 - Evolução dos estratos de renda e proporção de PEA/PIA e Ocupados/PIA nos domicílios, segundo faixa de RDPC na RMSP, 1991-2010. 118 
APRESENTAÇÃO ................................................................................................................ 15

INTRODUÇÃ

CONSIDERAÇÕES SOBRE O OBJETO DE ESTUDO ............................................. 22

1 MERCADO DE TRABALHO, POBREZA E PROTEÇÃO SOCIAL NO

BRASIL

1.1 Interpretações sobre as transformações do mercado de trabalho no Brasil e na Região Metropolitana de São Paulo .................................................................... 27

1.2 Notas sobre a construção institucional do mercado de trabalho no Brasil ... 35

1.3 Evolução recente das políticas sociais de combate à pobreza ............................. 41

1.4 Novas perspectivas sobre pobreza e trabalho ....................................................... 45

1.5 Considerações conclusivas e pontos em aberto para uma proposta de investigação..................................................................................................................... 53

2 REGIMES DE PROTEÇÃO SOCIAL, ESTRUTURA OCUPACIONAL E DESIGUALDADES..................................................................................................... 57

2.1 Introdução ................................................................................................................. 57

2.2 Regimes de proteção social e desmercantilização ................................................ 58

2.3 Mercado de trabalho e estrutura ocupacional na transição dos regimes de

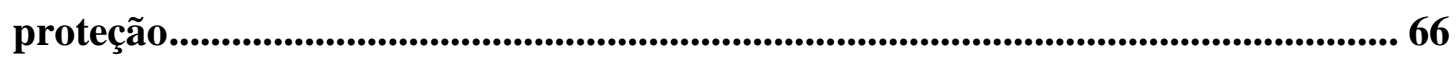

2.4 Configuração institucional e evolução da estrutura ocupacional..................... 72

2.5 Situando as metrópoles no debate sobre transformações na estrutura ocupacional ................................................................................................................... 76

2.6 Considerações e apontamentos para a condução do estudo empírico ............. 79

3 PADRÕES DE EVOLUÇÃO DA ESTRUTURA OCUPACIONAL E POBREZA

NA REGIÃO METROPOLITANA DE SÃO PAULO ............................................... 83

3.1 Retomando as mudanças e continuidades no mercado de trabalho da RMSP

3.2 Oferta e estrutura salarial............................................................................... 87

3.3 Formulação das hipóteses ...................................................................................... 90 
3.4 Metodologia para análise da evolução da estrutura ocupacional e resultados

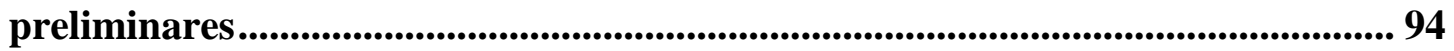

3.5 Evolução da estrutura ocupacional nos 1990 e nos 2000 ................................. 100

3.6 Uma primeira tentativa de discussão com a literatura ................................. 115

3.7 Estrutura ocupacional, proteção social e pobreza ................................................ 118

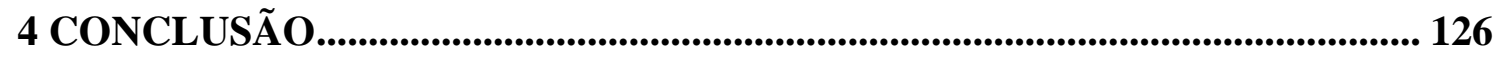

4.1 Retomando o debate ............................................................................................. 126

4.2 Retomando os achados e apontamentos................................................................. 129

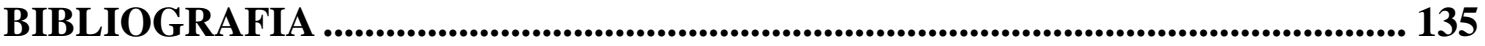

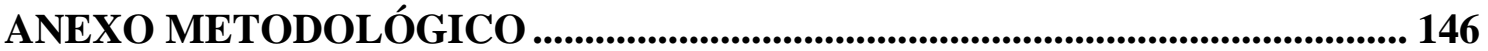




\section{APRESENTAÇÃO}

Este é um estudo sobre estrutura ocupacional, pobreza e proteção social e, até aqui, um longo caminho foi percorrido. Entretanto, o que aqui apresentamos guarda uma distancia com o ponto de chegada vislumbrado dois anos e meio atrás.

Quando do inicio dessa pesquisa, o objetivo principal era traçar os mecanismos de sociabilidade que permeavam a inserção de indivíduos ditos "pobres" no mercado de trabalho, com foco para beneficiários do Programa Bolsa Família; como seu contraponto, far-se-ia a análise dos chamados "pobres não beneficiários". Do ponto de vista teórico, tratava-se de articular dimensões relativas ao mercado (no caso, de trabalho) e às políticas públicas/sociais em contextos de pobreza, de modo que o estudo empírico teria duas fases. Uma primeira, quantitativa, que seria feito com os dados do CadÚnico, cedido pelo Ministério do Desenvolvimento Social e Combate à Fome do Governo Federal. E uma segunda, de cunho qualitativo.

Em meio às investidas da primeira parte do estudo empírico, inúmeras dificuldades surgiram com o tratamento do banco do CadÚnico - justamente por ser um banco de dados administrativo e de gestão, sujeito às dinâmicas políticas locais. Especialmente para as análises do mercado de trabalho da RMSP, o banco era pouco útil em virtude das suas deficiências de atualização. No que optamos pelos Censos Demográficos como uma alternativa viável.

Esta foi a proposta levada para banca de qualificação em julho de 2012. Entretanto, os professores da banca sugeriram que, em se tratando dos avanços já obtidos em relação ao tema do mercado de trabalho e pobreza, fosse mais frutífero focar o estudo empírico em uma análise quantitativa mais detalhada sobre o tema. E foi seguindo tal sugestão, e conduzidos pelas novas leituras no tema, que acabamos nos direcionando para explorar a temática da estrutura ocupacional e sua relação com a proteção social e a pobreza.

Este é, portanto, o tema da pesquisa que segue nas paginas seguintes, em que estudamos o caso da Região Metropolitana de São Paulo entre os anos de 1991 e 2010. 


\section{INTRODUÇÃO}

Este estudo tem por objetivo trazer a analise da estrutura ocupacional para o centro do debate sobre mercado de trabalho e pobreza. Interessa-nos expandir o foco meramente centrado na renda e/ou nos indicadores relativos a desemprego e salários, para compreender como a estrutura ocupacional constitui mecanismo de mediação entre as transformações econômicas, a configuração institucional do sistema de proteção social e a pobreza. Tentaremos mostrar como, ao analisar as transformações na estrutura ocupacional e alguns processos econômicos e regulatórios que a ela se associam, podemos traçar interpretações sobre a evolução da pobreza. Para tal, tomamos a Região Metropolitana de São Paulo como caso a ser estudado, focalizando as transformações que ali tiveram lugar entre os anos de 1991 e 2010.

No Brasil, as formulações e interpretações sobre a pobreza trazem consigo, historicamente, a estreita relação que se estabeleceu entre o processo de expansão do assalariamento formal e o sistema de proteção social. São processos que, combinados, produziram - junto com outros fatores - a reduzida capilaridade e efetividade das políticas de proteção, ao mesmo tempo em que esculpiram um mercado de trabalho heterogêneo e multifacetado, como num duplo jogo contingencial em que um é o suplemento do outro. A despeito da diversidade de interpretações, podemos resumir o argumento genérico da seguinte forma: o modelo de proteção social que se estabelecera após os anos 1930 ao tempo em que instituiu direitos e sujeitos de direitos, descaradamente de base ocupacional, produziu um sem-número de não-cidadãos porque sem direito à proteção social - justamente em virtude da ausência de uma regulação de abrangência universal (Santos, 1979; Machado da Silva, 1991). E a recíproca não seria menos verdadeira: num contexto de "cidadania ocupacional", o projeto de desenvolvimento estaria na expansão dos setores modernos da economia, de sorte que o amplo contingente de não-cidadãos fosse gradativamente absorvido a partir do estabelecimento de relações assalariadas formais que, justamente por isso, lhes garantiria o passaporte para a cidadania (e a sua consequência lógica e efetiva, o direito à proteção social). Tal projeto, todavia, encontrava suas principais barreiras no caráter funcional mesmo das formas "não-capitalistas" de trabalho ao processo de expansão e reprodução do capital num contexto de dependência internacional (Oliveira, 2003; Kowarick, 1975). 
Esta é a narrativa sobre a qual se assentou boa parte da discussão seja sobre o desenvolvimento e o regime de proteção social brasileiro, seja sobre os desafios de se compreender uma sociedade que se tornava cada vez mais capitalista mas donde o assalariamento não se generalizava. A partir dela foram forjadas categorias como "marginalidade", "informalidade" e "pobreza urbana", num exercício explicativo que colocava em evidencia a "funcionalidade do atraso" face ao modelo de desenvolvimento vigente.

Sendo assim, a pobreza foi pensada em boa parte da historia do Brasil como a face atrasada de um país que se pretendia (e se fazia) moderno (Telles, 2001). Mas antes que fruto de um "desmantelamento do Estado", era justamente a incompletude da construção de um genuíno sistema de proteção social (e por consequência da cidadania) e de um amplo mercado interno (de trabalho assalariado e de consumo) que forneciam as bases institucionais e os parâmetros estruturais do fenômeno. Mesmo o "setor informal" - que não se reduzia à pobreza, mas com ela se confundia - e constituía categoria de entendimento "por contraste" do seu oposto "formal", partia de uma lógica de compreensão estrutural dos problemas de integração social e econômica do desenvolvimento do capitalismo terceiromundista, comumente equacionados no trinômio industrialização/urbanização/assalariamento (Machado da Silva, 2003).

Ao longo dos anos 1990, entretanto, uma série de mudanças passou a alterar tanto a forma como o mercado de trabalho se articulava à pobreza, como também ao sistema de proteção social. Por um lado, o país finalmente consolidava o seu mais universalista marco legal de proteção social, que a desvinculou, em boa medida, do mercado de trabalho, graças aos parâmetros colocados pela Constituição de 1988; essa cobertura tem se ampliado sistematicamente desde então (Draibe, 2002; Kerstenetzky, 2012). Por outro, entretanto, e seguindo na esteira da "reestruturação produtiva" e da abertura dos mercados nacionais, o mercado de trabalho sofreu fortemente com a nova dinâmica imposta pela reestruturação micro-organizacional intensificada nos anos 1990 e pela flexibilização das relações de trabalho, aprofundada em meados dos anos 1990. A Região Metropolitana de São Paulo mostrou-se um caso exemplar da intensidade com que esses processos ocorreram entre nós. 
Pela primeira vez em mais de 40 anos assistia-se a uma inflexão negativa no processo de assalariamento formal. A literatura especializada rapidamente identificou as rupturas de trajetórias no mercado de trabalho e as novas - e mais intensas - formas de rotatividade e instabilidade ocupacional (Guimarães, 2006; Cardoso, 2013). Tais instabilidades se refletiram também na ruptura de horizontes das trajetórias individuais e familiares, no cotidiano das relações sociais (Kowarick, 2003; Telles e Cabanes, 2006); e, novamente, a dinâmica do assalariamento formal (mas agora sua redução, e não sua expectativa de expansão) fornecia parte das bases interpretativas para o fenômeno da pobreza.

Os anos 2000, em especial a partir da sua segunda metade, colocaram sob suspeita algumas das previsões do período anterior. O mercado de trabalho continuou a experimentar parte das mudanças que se iniciaram nos 1990 (ampliação dos setores de comércio e serviços e queda da participação da industria, aumento do emprego terceirizado e temporário, dentre outras) mas, diferentemente da década anterior, o país vivenciou um ciclo de crescimento, com forte queda nas taxas de desemprego, informalidade e pobreza. Como resultado, um elevado contingente de trabalhadores foi incorporado ao setor formalizado do mercado e, na esteira dessas transformações recentes, tem se acalorado o debate sobre a possível emergência de uma "nova classe média" (Neri, 2011; Pochman, 2012; Souza, 2012, dentre outros). Não obstante, essa inclusão tem se dado justamente num contexto de forte flexibilidade contratual e instabilidade ocupacional, de modo que aquilo que foi tratado a partir dos anos 1980 nos países de capitalismo avançado como uma perda de direitos consequente à chamada "crise do Welfare State", aqui tem sido visto como a porta de entrada para o mercado formal e de consumo que se abriu para alguns milhões de trabalhadores.

Naqueles países, por outro lado, a construção institucional de um mercado de trabalho livre e assalariado remete aos princípios fundadores do capitalismo moderno (desde Marx a Polanyi, Esping-Andersen, Offe, dentre outros). Independentemente das variações interpretativas sobre as "causas" da emergência do Welfare State, é ponto comum que a proteção social surge no bojo de uma lógica de organização modernoindustrial, donde se alteram os papéis da família/comunidade enquanto instituições de promoção do bem-estar, a partir do crescente processo de desenvolvimento e capilaridade do mercado como instituição ordenadora das relações sociais. Por outro 
lado, e seguindo Polanyi, o principio da proteção social, atuando por meio de dispositivos institucionais de Estado, configura o movimento contrário à expansão da mercantilização da vida social e da força de trabalho potencial, formatando a configuração do mercado de trabalho. Nessa trajetória, durante boa parte do século XX o binômio fordismo-Welfare State constituiu o principal referencial de promoção do bem-estar.

As mudanças no capitalismo central e que se exprimiram a partir de 1970 colocaram em evidencia uma nova lógica de ordenamento social e de possibilidades/limites para a intervenção estatal; isso deu lugar a transformações no padrão de desigualdade e na estrutura ocupacional. O debate acadêmico tem mostrado que existe uma forte associação entre os tipos de empregos gerados a partir de 1980, as mudanças na composição da oferta e da demanda por trabalho, e o comportamento dos indicadores de desigualdade (Acemoglu, 1999 e 2002; Autor et al, 2003; Acemoglu e Autor, 2010; Goos e Manning, 2007; Goos et al, 2009, Wright e Dwyer, 2003, dentre outros). Entretanto, esta associação - e por conseguinte, a variação entre os países - é fortemente tributária do arcabouço das instituições do mercado de trabalho e de proteção social (Sharpf e Shimidt, 2000; Gallie e Paugam, 2004a; DiPrete et al, 2005; Mimieux, 2007; Gallie, 2007; Mouw e Kalleberg, 2010; Kalleberg, 2012; FernandezMacías, 2012; Oesch e Menés, 2012). Isso nos tem proporcionado uma linha interpretativa que, se bem não seja originalmente dirigida à temática da pobreza em si, pode nutrir, acreditamos, uma boa reflexão no sentido de bem compreender-se a dinâmica da pobreza na RMSP.

Partindo dessa literatura, e balizados pelas especificidades que guardam a trajetória do mercado de trabalho e da proteção social no Brasil e na Região Metropolitana de São Paulo, conduzimos nosso estudo. A nossa principal hipótese é a de que podemos compreender a evolução da pobreza a partir a partir das transformações na estrutura ocupacional, sempre atentos ao contexto institucional e às mudanças econômicas que a condicionam. Mais especificamente, sugerimos que o padrão de evolução da estrutura ocupacional na RMSP nos 1990 e nos 2000 foi substancialmente distinto, e atentar para tal distinção nos permitirá tecer considerações relevantes e agregar potencial explicativo ao entendimento da dinâmica da pobreza nesses dois períodos. 
Esta dissertação se encontra organizada da seguinte forma. Primeiramente, tecemos considerações sobre o objeto de estudo. No primeiro capítulo apresentamos algumas das transformações do mercado de trabalho na Região Metropolitana de São Paulo e algumas interpretações que lhe seguiram. Posteriormente, discutimos o processo de expansão do assalariamento, do sistema de proteção social no Brasil e algumas interpretações sobre a pobreza. Ao final, discutimos e apontamos questões em aberto, justificando o objeto de pesquisa.

No segundo capitulo apresentamos o debate relativo à relação entre proteção social e estrutura ocupacional nos países de economia avançada, bem como este debate repercutiu nas interpretações sobre as transformações das metrópoles no mundo contemporâneo.

O terceiro capitulo retoma algumas das transformações do mercado de trabalho e da atividade econômica na RMSP para, em seguida, formularmos as principais hipóteses de pesquisa. O restante do capitulo apresenta a metodologia, os resultados e as interpretações.

Ao final, concluímos retomando o debate com a literatura trabalhada e os resultados do estudo empírico. 


\section{CONSIDERAÇÕES SOBRE O OBJETO DE ESTUDO}

Ao longo das décadas de 1990 e 2000 assistimos, tanto no Brasil como na Região Metropolitana de São Paulo, a uma série de mudanças que perpassaram a estrutura produtiva e organizacional (demanda por trabalho), as características dos trabalhadores e de suas famílias (composição da oferta e estratégias de inserção), a estrutura ocupacional e salarial (que podem ser vistas como resultados do encontro entre oferta e demanda no mercado de trabalho), o escopo da proteção social e a regulação do mercado de trabalho e, por fim, variações nos indicadores relativos à incidência da pobreza.

Quanto a esta última, e do ponto de vista da sua teorização, a literatura tratou de chamar a atenção para suas novas configurações em face de um capitalismo globalizado e de um mundo do trabalho cada vez mais desarticulado. Primeiramente, emergiram interpretações na esteira de concepções como "exclusão social" e "vulnerabilidade", para posteriormente se articularem em torno de temas como a fragmentação das trajetórias individuais e familiares (Telles e Cabanes, 2006; Guimarães, 2009) tecidas por sobre os diferentes jogos de poder nos meandros da circulação global do capital e de suas interfaces com o Estado (Telles e Cabannes, 2006).

Mais especificamente em relação ao mercado de trabalho, e já em meados dos anos 1990, temas como a precarização do trabalho e o desemprego estrutural forneceram os principais motes para o debate. O diagnóstico de que a reestruturação produtiva se fizera com significativos ganhos de produtividade e de que a racionalização promovida pela reorganização micro-organizacional produzira um elevado contingente de trabalhadores considerado "dispensável” ou "redundante” (ou que não seria “empregável”, para usar os termos da época), levou a prognósticos nada animadores (Guimarães 2004; Dedecca, 2002). Ademais, ampliou-se a já histórica e elevada rotatividade no mercado e o tempo de procura por trabalho, bem como reduzia-se o tempo de permanência no emprego (Guimarães, 2006; 2009). Tal tendência à fragilização dos vínculos se manteve presente na última década, a despeito da retomada do crescimento a partir de meados dos 2000 até os anos mais recentes (Guimarães, 2011). 
Tomando alguns dados dos Censos Demográficos (IBGE) das edições de 1991, 2000 e 2010 para a RMSP - e mesmo cientes de que não nos permitem captar dinâmicas internas a cada uma das décadas - apresentamos o Gráfico 1 abaixo que ressalta algumas mudanças nos indicadores relativos à relação entre pobreza ${ }^{1}$ e mercado de trabalho nesse período. De inicio, podemos observar a elevação das taxas de pobreza e desocupação entre 1991 e 2000 para declinarem em 2010. O mesmo se passa com relação ao percentual de pessoas que, ocupadas ou não, se encontravam também na condição de pobreza ao longo desses anos.

Gráfico 1 - Indicadores de pobreza e mercado de trabalho na RMSP, 1991-2010

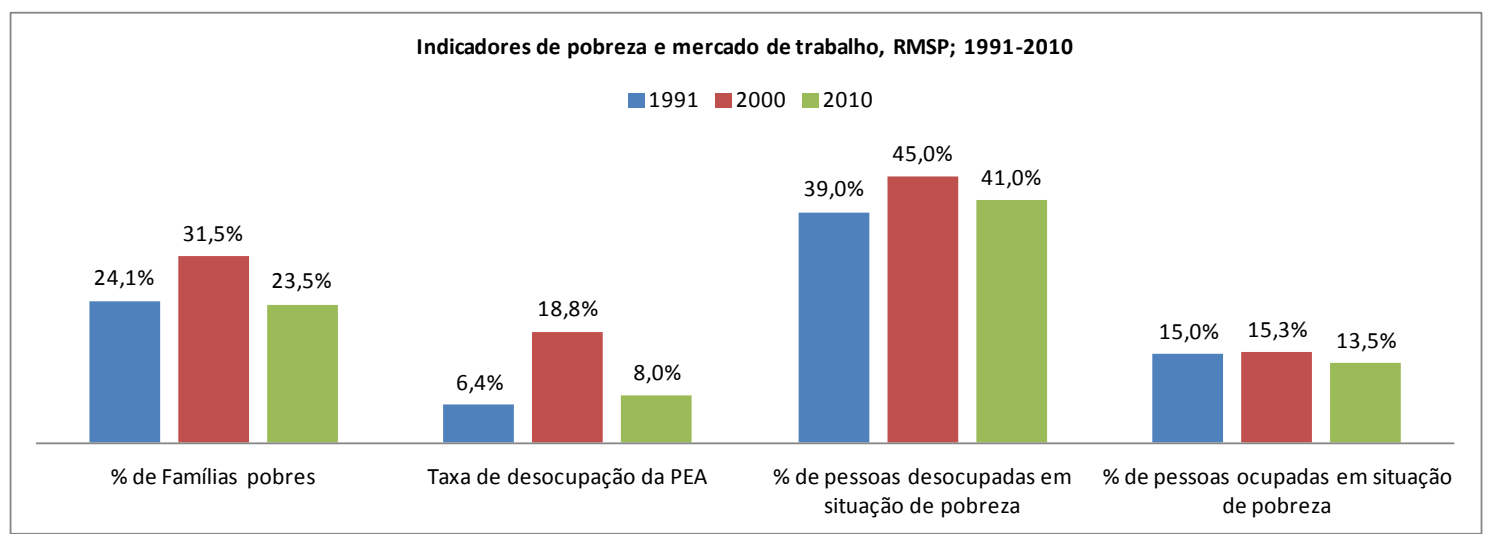

Fonte: Microdados dos Censos Demográficos (IBGE), 1991, 2000 e 2010. Elaboração própria.

Estes primeiros dados reiteram um achado recorrente na literatura do campo (Machado et al, 2007; Cappelari e Jenkins, 2002; dentre outros), que aponta para a íntima associação entre a intensidade da pobreza e o comportamento do mercado de trabalho. Considerando-se que nos meios urbanos o trabalho se constitui na principal via de obtenção da renda, quanto mais adversas as condições do mercado de trabalho, maior a tendência a que um número crescente de pessoas se encontre em situação de pobreza.

Por outro lado, não permitem visualizar boa parte das transformações a que fizemos referência na página anterior. Para nos atermos apenas a uma delas, destacamos abaixo (Tabela 1) algumas mudanças na estrutura salarial ao longo do período analisado, em especial a forte expansão do estrato médio inferior (mais de $1 \mathrm{SM}$ a $2 \mathrm{SM}-\mathrm{R} \$ 510$ a

\footnotetext{
1 Segundo linha de pobreza calculada por Sônia Rocha, disponível em www.iets.org. Os valores deflacionados para julho de 2010 são de R\$281,55 em 1991, R\$337,05 em 2000 e de 330,18 em 2010.
} 
$\mathrm{R} \$ 1020$ - em valores de 2010) $)^{2}$ em ambas as décadas, que cresceu 18,3\% e 12,1\% em termos relativos. Mas, ao observarmos o número total de pessoas em cada um dos estratos e as variações decenais, notamos que os anos 2000, diferentemente dos 1990, se caracterizaram pela forte criação de postos de trabalho de até 2 salários mínimos: nada menos do que 1,35 milhão de empregos nessa faixa foram criados entre 2000 e 2010, contra 870 mil da década anterior. No que concerne ao estrato inferior da distribuição (até 1SM), a sua participação relativa no total de novos postos foi de aproximadamente $20,0 \%$ entre 2000 e 2010, enquanto que de 1991 a 2000 tal participação não passou de $1,2 \%$.

Tabela 1 - Estrutura salarial da RMSP, 1991-2010

\begin{tabular}{|l|ccc|cc|}
\hline Estrutura salarial (\%) & 1991 & 2000 & 2010 & Var 91-00 & Var 00-10 \\
\hline Até 1 SM (R\$510) & $19 \%$ & $15,90 \%$ & $16,30 \%$ & $-16,5 \%$ & $2,8 \%$ \\
Mais de 1SM a 2SM (R\$510,01 a R\$1020) & $31,20 \%$ & $37 \%$ & $41,40 \%$ & $18,3 \%$ & $12,1 \%$ \\
Mais de 2SM a 4SM (R\$1020,01 a R\$2040) & $27,80 \%$ & $25,20 \%$ & $23,20 \%$ & $-9,3 \%$ & $-8,1 \%$ \\
Mais de 4SM (R\$2040,01) & $21,90 \%$ & $21,90 \%$ & $19 \%$ & $0,1 \%$ & $-13,1 \%$ \\
\hline \multicolumn{1}{|c|}{ Total } & $100 \%$ & $100 \%$ & $100 \%$ & - & - \\
\hline Estrutura salarial (N) & 1991 & 2000 & 2010 & Var \% 91-00 & Var \%00-10 \\
\hline Até 1 SM (R\$510) & 1196739 & 1212951 & 1524215 & $1,4 \%$ & $25,7 \%$ \\
Mais de 1SM a 2SM (R\$510,01 a R\$1020) & 1963396 & 2818583 & 3863920 & $43,6 \%$ & $37,1 \%$ \\
Mais de 2SM a 4SM (R\$1020,01 a R\$2040) & 1749459 & 1925222 & 2163320 & $10,0 \%$ & $12,4 \%$ \\
Mais de 4SM (R\$2040,01) & 1373742 & 1668401 & 1772276 & $21,4 \%$ & $6,2 \%$ \\
\hline Total & 6283335 & 7625158 & 9323732 & $21,4 \%$ & $22,3 \%$ \\
\hline
\end{tabular}

Fonte: Microdados dos Censos Demográficos (IBGE), 1991, 2000 e 2010. Elaboração própria.

Esta evolução da estrutura salarial evidencia, por um lado, o processo de aumento do desemprego, resultante do "enxugamento" de boa parte das ocupações de base, concomitante ao crescimento da informalidade nos anos 1990; por outro lado, revela a retomada do crescimento, ocorrida na segunda metade dos 2000, ancorado em ocupações remuneradas em até dois salários mínimos, que se fez ao tempo em que ocorria a retomada do assalariamento formal.

Certamente, como ressaltam alguns autores (Baltar et al, 2010; Kerstenetzky, 2012, Pochman, 2012; dentre outros) esta dinâmica da estrutura salarial associada aos valores

${ }^{2}$ Os estratos salariais estão aqui expressos em valores de 2010, quando o salário mínimo era de $\mathrm{R} \$ 510,00$. Ou seja, os indivíduos que em 1991 e 2000 recebiam $\mathrm{R} \$ 510$ em valores de 2010, por exemplo, tinham um rendimento superior ao do salário mínimo da época. 
reais do salário mínimo foi um componente central para moldar a relação que se estabeleceu entre pobreza e mercado de trabalho nessas décadas. Mas gostaríamos de destacar, para ilustrar o argumento que pretendemos desenvolver ao longo dessa dissertação, outros dois fatores que medeiam essa relação.

Em primeiro lugar, é fato que, observando-se do ponto de vista do mercado de trabalho, os ganhos monetários têm o salário individual como parâmetro de mensuração. Não sem razão, já que o mercado que se erige para fazer circular o trabalho é um modo de organização social assentado numa dupla disposição do indivíduo: a de vender sua força de trabalho e, em troca, aceitar receber uma quantia determinada, um salário. Já a pobreza é uma condição vivenciada por indivíduos que se integram em núcleos familiares ou domiciliares. Assim, no mercado de trabalho a renda é auferida individualmente ${ }^{3}$. Diferentemente, quando tratamos e medimos a pobreza, ela está habitualmente referida à composição de ganhos de um núcleo familiar ou domiciliar. Desse modo, é perfeitamente possível que um trabalhador tenha um salário relativamente "bom" mas que, em função da composição do seu grupo familiar ou domiciliar, viva em situação de pobreza; ou o contrário: um trabalhador pode ter um baixo salário, mas viver em um domicílio (ou num grupo familiar) cuja soma dos rendimentos ultrapasse a condição de pobreza.

Um segundo mediador relevante para pensarmos a relação entre mercado de trabalho e pobreza se refere ao escopo de atuação do Estado ou, para dizê-lo mais especificamente, ao escopo das políticas de proteção social. Assim, se aceitarmos com Esping-Andersen (1990) que "Família, Estado e Mercado são as três principais instituições de promoção do bem estar em sociedades modernas", devemos ter em conta que a intensidade da pobreza resulta não apenas do quanto o indivíduo aufere no mercado de trabalho e nem somente do modo como ganhos são alavancados num grupo domiciliar ou familiar, mas ela também reflete o modo pelo qual o Estado garante as condições de reprodução dos indivíduos via mecanismos não mercantis de acesso ao bem estar. E, tal como argumentaremos mais à frente, o modelo de atuação do Estado, nesses termos, acaba por trazer implicações também para a dinâmica da estrutura ocupacional, constituindo outro componente estrutural de mediação entre pobreza e mercado de trabalho.

\footnotetext{
${ }^{3}$ Embora esta renda possa depender de unidades não necessariamente individuais, como ocupação, setor de atividade econômica e nível educacional.
} 
Com base nessas considerações destacaremos, no próximo capítulo, algumas das principais transformações na estrutura do mercado de trabalho no Brasil e na Região Metropolitana de São Paulo no período compreendido entre 1991 e 2010, enfatizando continuidades e rupturas. Em seguida, trataremos da relação entre o processo de expansão do assalariamento e o regime de proteção social que se consolidou no Brasil.

Há um triplo objetivo subjacente ao interesse em retomar essas questões. Em primeiro lugar, o de situar esse processo como modelador da relação entre mercado de trabalho e pobreza no Brasil. Em segundo, salientar a peculiaridade do caso brasileiro, para contrapô-lo ao modelo "clássico", típico dos países de economia avançada. E, em terceiro, mostrar como boa parte das perspectivas interpretativas sobre os elos entre pobreza e mercado de trabalho se desenvolveu (com razão) a partir dessa peculiaridade brasileira concernente à expansão do assalariamento, mas sem colocar em questão como a relação entre estrutura ocupacional e proteção social a este se articula.

Esta é, destarte, a principal questão que nos move, qual seja: a de entender a relação entre mercado de trabalho e pobreza a partir das transformações na estrutura ocupacional, sem perder de vista os condicionantes estruturais colocados pelos sistemas de proteção social. Desta forma, ao final do capitulo próximo nos deteremos primeiramente sobre como o processo de expansão do assalariamento constitui um ponto chave da articulação que nos interessa desenvolver para, em seguida, argumentarmos no sentido de que há pontos em aberto deixados pela literatura que se debruçou sobre a relação entre pobreza e trabalho.

Estes pontos em aberto dizem respeito justamente à possibilidade de um tratamento sistematizado da estrutura ocupacional de modo a permitir traçar considerações sobre a relação entre mercado de pobreza e trabalho. Nesse quesito, o capítulo 2 apresentará algumas abordagens teóricas das quais, balizadas pelo que será apresentado neste primeiro capítulo, nos nutriremos para a realização do estudo empírico. 


\section{MERCAdo DE TRABALHO, POBREZA E PROTEÇÃo SOCIAL NO BRASIL}

\subsection{Interpretações sobre as transformações do mercado de trabalho no Brasil e na Região Metropolitana de São Paulo}

Os anos 1990 foram marcados por uma profunda transformação da atividade econômica e do mercado de trabalho no Brasil. Assistiu-se, para citar alguns aspectos de cunho estrutural, ao que, no jargão da época, costumava ser referido como a busca por competitividade num capitalismo globalizado. Tais transformações se expressaram na retração da presença do Estado na produção direta e consequentes privatizações, num intenso movimento de fusões e aquisições que alinhou as empresas brasileiras a cadeias produtivas internacionais, na abertura econômica, na supressão das barreiras de proteção à industria e no crescimento da importação de produtos manufaturados. Este processo de reestruturação produtiva trouxe mudanças nos cenários tanto macroeconômico quanto micro-organizacional, já que as firmas passaram a adotar novas formas de gestão da produção e do trabalho, reduzindo níveis hierárquicos, externalizando atividades, encolhendo seus efetivos e engajando-se em modalidades distintas de contratação, tais como as formas de trabalho terceirizado e temporário, consequentes a um movimento de flexibilização das modalidades contratuais. Mais ainda, toda essa mudança, multifacetada, deflagrou-se num contexto de crise econômica e de retração da atividade produtiva, que marcou o alvorecer dos anos 1990; o custo social embutido nessas transformações não deixava de ser paradoxal, se considerarmos que eram ainda recentes os efeitos cívicos da aprovação de uma nova Constituição socialmente progressista e do retorno à normalidade democrática.

A Região Metropolitana de São Paulo (RMSP), principal centro dinâmico e industrial do país, absorveu rapidamente os impactos das mudanças. Embora o processo de desconcentração industrial tivesse começado já no inicio dos anos 1980, os 1990 aprofundaram essa tendência. E, se bem seja certo que tal desconcentração se deu de maneira concentrada, expandindo-se para regiões próximas à RMSP (Campolina e Campolina Diniz, 2007), e conquanto estivesse associada ao fato de que serviços anteriormente prestados no interior da grande indústria passam a se estabelecer fora 
dela, o cenário configurado foi o de uma forte queda do emprego na Região, notadamente do emprego industrial. Como bem ressaltaram os autores acima citados, essa queda não se refletiu na produção com a mesma intensidade, a evidenciar um processo de reestruturação, antes que de desindustrialização (ibid). Comin e Amitramo (2003) argumentam na mesma linha, ressaltando que o crescimento da atividade terciária em São Paulo que teve lugar nos anos 1990 evidenciava o vigor remanescente da sua indústria, e não um processo de "terciarização" da metrópole.

Mas o que chama a nossa atenção, para fins do interesse deste trabalho, são as transformações ocorridas no tipo de emprego que então se consolida, do que são ilustrativos os gráficos a seguir apresentados. É certo que a participação da indústria no volume total de empregos cai de 1/3 em 1991 para menos de 1/5 em 2010, em contraposição ao forte crescimento do setor de serviços, tendência que continua na década seguinte, embora menos intensa (Gráfico 2). Entretanto, a despeito do forte crescimento das atividades de comércio e distribuição, e evidenciando quão longe estávamos de uma desindustrialização no sentido estrito, o que mais se destaca na última década é o comportamento do subsetor de "Serviços prestados a empresas", retratando o incremento das atividades terceirizadas e/ou de agenciamento e contratação (Gráfico 3). Embora a participação relativa desse subgrupo ainda não chegue a 15\%, ele já se constitui como o terceiro principal empregador da RMSP. Na década de 2000, este subgrupo de atividades foi responsável pela geração de quase 600.000 postos de trabalho, ficando atrás apenas do setor de "comércio e distribuição".

\footnotetext{
4 Também chama atenção o comportamento dos "Serviços Sociais", retratando a entrada do capital privado no setor. O comportamento desse tipo de serviços é fator crucial para compreendermos a dinâmica da estratificação social e dos tipos de empregos que se criam, em especial na base da pirâmide (Esping-Andersen, 1999). Trataremos desses pontos nos capítulos subsequentes.
} 
Gráfico 2 - Participação relativa dos setores de atividades econômicas (ISIC) no volume total de empregos, RMSP; 1991-2010

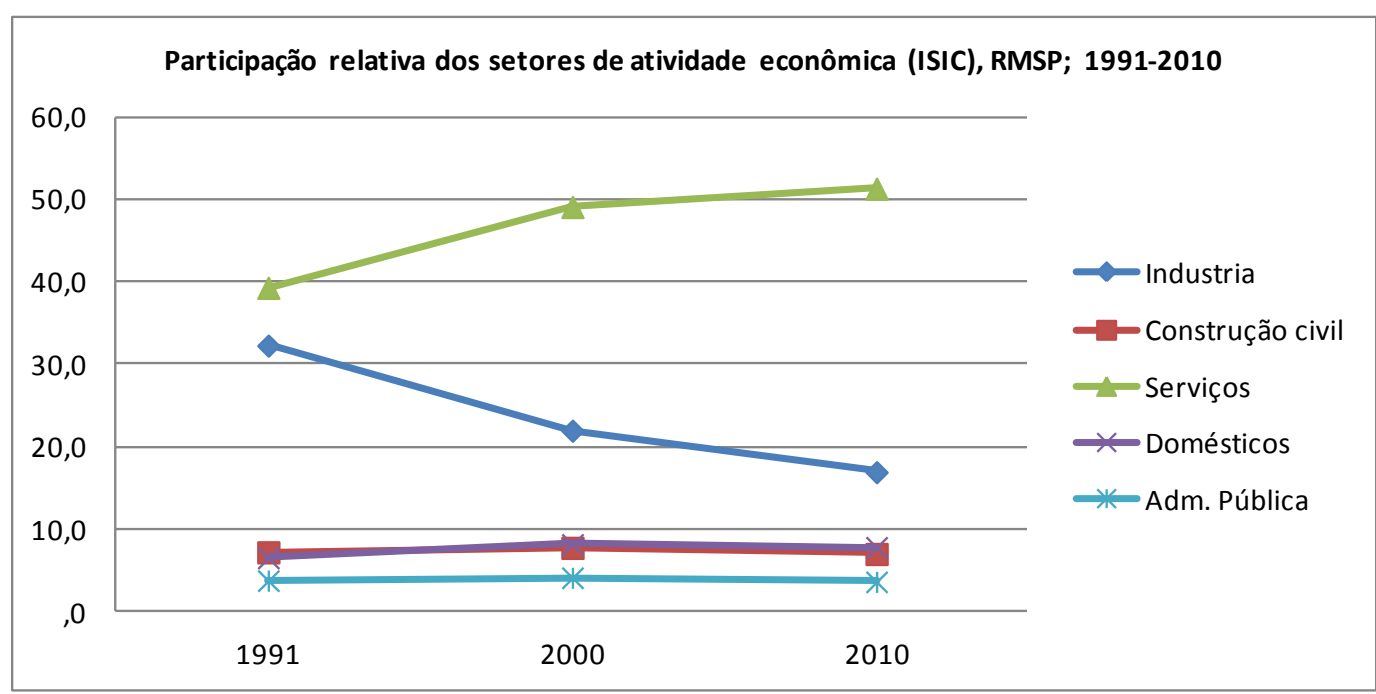

Fonte: Microdados dos Censos Demográficos (IBGE), 1991, 2000 e 2010. Elaboração própria.

Gráfico 3 - Total de empregos gerados nos subsetores de "Serviços", RMSP; 1991-2010

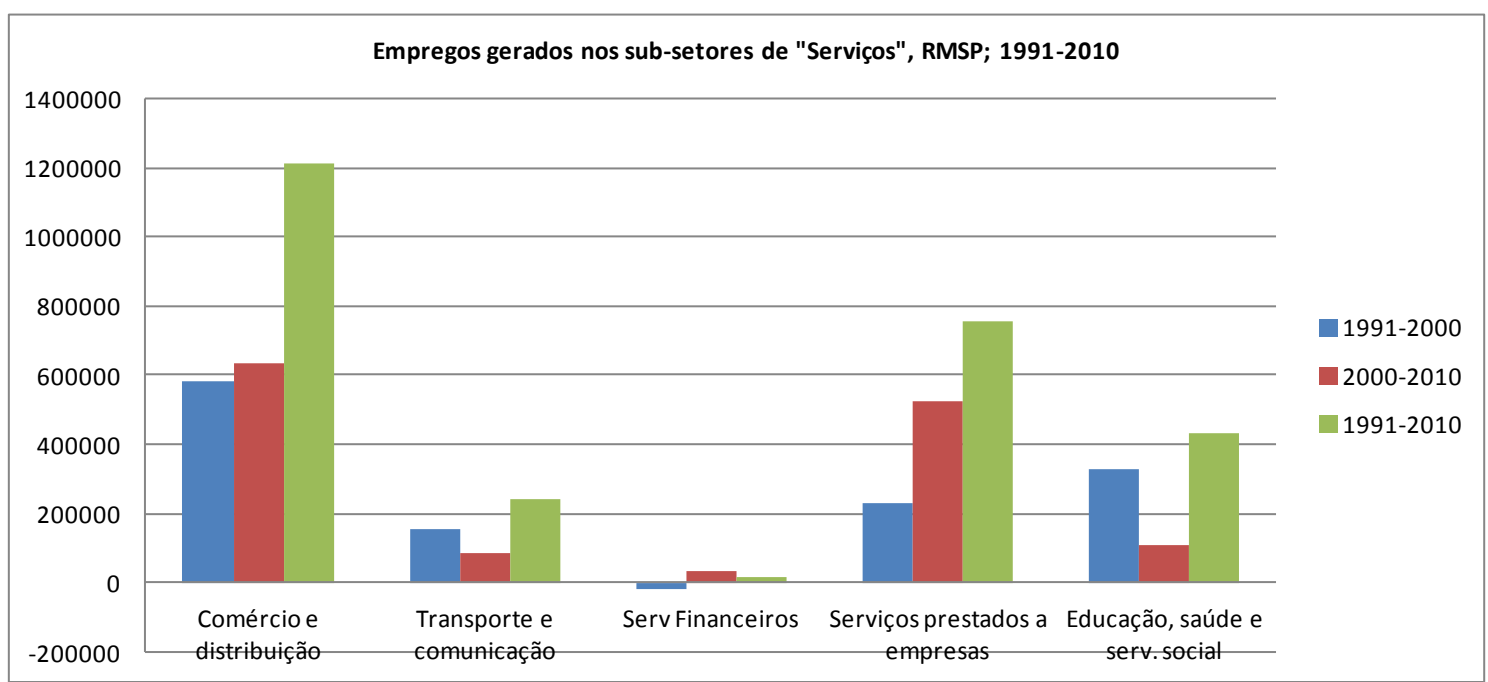

Fonte: Microdados dos Censos Demográficos (IBGE), 1991, 2000 e 2010. Elaboração própria.

Essas tendências vieram acompanhadas de um forte crescimento do desemprego nos primeiros anos da década de 1990 (em especial o desemprego oculto pelo trabalho precário ou pelo desalento), infletindo negativamente logo após a estabilização monetária em 1994 e voltando a crescer a os partir de 1995, embora com uma suave queda de 1999 para 2000 (Guimarães, 2006). 
No plano das relações trabalhistas, uma série de medidas foi adotada pelo governo federal apoiando-se no discurso de tornar o mercado de trabalho brasileiro mais competitivo defronte a uma economia cada vez mais integrada mundialmente: contrato por tempo determinado, trabalho em tempo parcial, suspensão do contrato por motivos econômicos, banco de horas, redução do salário com a redução da jornada ${ }^{5}$. Em seu conjunto, alguns autores argumentam que tais medidas representaram um retrocesso no tocante às relações de trabalho tal como estabelecidas formalmente pela CLT, num processo marcado por uma guinada de "precarização" (Krein, 2003; Costa, 2005). Em paralelo, verificou-se um sucateamento do sistema de fiscalização do trabalho, criando as condições institucionais para o estabelecimento de relações de trabalho à revelia da lei (Baltar et al, 2010), ao mesmo tempo em que, como argumenta Noronha (2003), a flexibilização da CLT transferiu para o campo das negociações cotidianas aquilo que anteriormente se encontrava inscrito na lei.

Escrevendo no "calor do momento", os prognósticos futuros na transição dos 1990 para os 2000 não se mostravam nada otimistas. Para ficarmos apenas no mercado de trabalho da RMSP, Comin e Amitrano (2003) afirmavam que a flexibilização das relações trabalhistas em face da nova estrutura produtiva significou um rearranjo do mercado de trabalho da metrópole que parecia marcar um novo tipo de heterogeneidade e polarização, refletindo o vertiginoso crescimento de um desestruturado setor de serviços. Também não é raro encontrarmos afirmações de que o "desemprego estrutural havia vindo para ficar" e que a precarização havia se tornado o traço dominante do mercado de trabalho brasileiro (Costa, 2005).

De fato, não foram apenas os indicadores estáticos do mercado de trabalho que haviam se deteriorado. Uma importante mudança havia se passado na sua própria dinâmica interna, qual seja, a intensificação da transitividade ocupacional marcada por uma sorte de instabilidade no que concerne aos modos de inserção. Embora a alta rotatividade sempre tenha sido uma constante histórica do mercado brasileiro (Hoffman, 1980; Humphrey, 1982; Guimarães, 2006; Cardoso, 2013), este padrão se alterou ao longo dos anos 1990, que lhe conferiu um novo significado. Tal como mostraram os estudos que focalizaram os trabalhadores industriais, analisando o período 1989-2003, a trajetória dos desligados em diferentes ramos da atividade manufatureira deixou de se caracterizar

\footnotetext{
${ }^{5}$ Para mais detalhes ver: Krein, 2003.
} 
pelas elevadas chances de reinserção na mesma ocupação/setor ao qual haviam estado vinculados ${ }^{6}$ para se caracterizar por percursos que levavam maciçamente à exclusão do mundo dos empregos formais (Guimarães, 2004; Cardoso,2000).

Aqueles trabalhos que fixaram a atenção no padrão de trajetórias dos trabalhadores metropolitanos, independentemente do seu setor, apontavam para um resultado que se tornava ainda mais desconcertante: o tipo de percurso mais recorrente na região metropolitana de São Paulo era caracterizado por transições tão intensas entre desemprego, ocupação e inatividade que não chegava sequer a ser possível reconhecer um padrão bem estabelecido que tipificasse essas trajetórias (Guimarães, 2006 e 2009; Cardoso, 2013). Transitava-se com intensidade entre o formal, o informal, o desemprego e a inatividade, significando não somente uma nova dinâmica de privação e insegurança no percurso dos trabalhadores mas, mais do que isso, colocando em evidencia a pouca efetividade de um sistema de proteção social em assegurar posições estáveis e estabelecidas em relação ao mercado, notadamente incapaz de assegurar, como em outras metrópoles no capitalismo avançado, que os indivíduos pudessem, enquanto no desemprego aberto, dedicar-se à procura sistemática de trabalho. Este último ponto, em especial, é um aspecto chave e, por isso mesmo, a ele voltaremos diversas vezes neste capítulo, justamente porque interessa salientar que a construção do nosso mercado fez-se sem que a integração via assalariamento formal houvesse se instituído e generalizado enquanto norma de emprego, sustentada em um sólido sistema de proteção social.

Nesse contexto, o índice de pobreza na Região Metropolitana de São Paulo em 2003 retrocede ao patamar de 1993 (um ano antes de haver caído bruscamente em virtude da estabilização monetária). Esse não é um fenômeno que particularize a RMSP; ao contrário, nesse momento a pobreza grassava nos principais centros urbanos do país. Por outro lado, se essa parecia ser uma tendência de longo prazo, os anos 2000 foram marcados por uma inflexão desses indicadores.

Após um inicio de década incerto, o ano de 2004 marca a retomada do crescimento do PIB estimulado pelo favorável cenário econômico internacional. A taxa de desemprego

\footnotetext{
${ }^{6}$ Guimarães argumenta que, até meados dos anos 1980, “o intenso turn-over era um instrumento por excelência de gestão, complementado pela repressão política. Mas ele não privava nem da chance (de longo prazo) da reinserção, nem - e por isto mesmo - da representação simbólica de uma identidade (profissional) e de um destino (ocupacional)" (Guimarães, 2006, p. 119).
} 
na RMSP volta a níveis relativamente baixos (na casa dos 8,0\%) em 2010, ao mesmo tempo em que a formalização do trabalho alcança elevados patamares. Cabe destaque, também, a valorização da ordem de 70\% do salário mínimo real, ocorrida entre 2003 e 2013, e as políticas de transferência de renda e de combate à pobreza postas em prática no período, com especial destaque para o Programa Bolsa Família.

Esses resultados conduziram a um debate acalorado sobre a possível emergência de uma "nova classe média" no Brasil. Enquanto alguns autores têm argumentado no sentido de que essa "nova classe" se distingue antes de tudo pelo seu padrão de consumo (Neri, 2012), outros têm enfatizado que o caráter "precário" de tal inserção no mercado de trabalho não sustentaria tal ideia; preferem usar, antes, termos como "precariado" (Braga, 2012) ou "novos batalhadores" (Souza, 2012), para ficarmos apenas com alguns deles.

Sem entrar no mérito desse debate, que expande em larga medida os nossos interesses, cabe assinalar que, se os números relativos ao desemprego, informalidade e pobreza deixam transparecer inegáveis ganhos na performance dos indicadores, é necessário atentar para o fato de que o mercado de trabalho reproduz algumas dinâmicas que contrabalanceiam essas tendências. Ao longo da última década, nota-se tanto um aumento da rotatividade, quanto a proliferação das novas formas de contratação, como empregos temporários, agenciados, de curta duração e terceirizados (Guimarães, 2011; Bicev, 2010). Em vez de desemprego recorrente, como nos anos 1990, é mais plausível reconhecer um contexto de "emprego recorrente". Cardoso (2013) e Guimarães (2011) argumentam que os trabalhadores tendem a ficar menos tempo nos empregos formais, os ditos "bons empregos", transitando sistematicamente entre diferentes posições no mercado. Mas não apenas isso: o problema continua a ser a incapacidade do mercado de trabalho em gerar

condições estruturais que garantam segurança ontológica para os diferentes grupos etários, e estamos muito longe disso. [...] Novos postos de trabalho são ocupados por novos entrantes e por pessoas que perderam seus empregos há não muito tempo atrás. $\mathrm{E}$ ambos, muito provavelmente, perderão seus empregos para outros, e num prazo muito curto. O mercado formal de trabalho pode ser uma "terra de sonhos" para boa parte dos trabalhadores, mas não é garantia de segurança no emprego. (Cardoso, 2013, s/ p.).

Assim sendo, nos parece importante atentar para o movimento aparentemente paradoxal empreendido pelo mercado de trabalho no pós 1990 no que concerne ao processo de 
expansão do assalariamento formal. Tal expansão havia se dado, desde a década de 1940, com a característica de que os inseridos no setor formal (na maioria das vezes situados nos setores modernos da industria e dos serviços) contavam com uma certa segurança no tocante à trajetória ocupacional, além de uma não desprezível cesta de direitos garantida pela legislação trabalhista (Guimarães, 2006). Aqueles que ali não se encontravam foram analiticamente tratados como "trabalhadores marginais" ou “trabalhadores informais", e deles trataremos na sessão seguinte. Ao longo dos 1990 assistimos a um processo de retração do assalariamento (em especial formalizado) que veio acompanhado de uma mudança não apenas na natureza da rotatividade e na ruptura de trajetórias, até então relativamente bem delineadas, mas também no tempo experimentado no desemprego, vale dizer, na forma de estruturação do mercado de trabalho.

Entretanto, como ressalta Guimarães (2011), se é certo que o elevado desemprego encontrava suas raízes na reestruturação micro-organizacional em um contexto de crise econômica e de abertura comercial, ficava patente um "ponto de não retorno" no que se refere à mercantilização da força de trabalho atingido já no início dos anos 1980, quando vivemos a primeira grande crise de desemprego de massa. E por "mercantilização" a autora está dizendo da

\footnotetext{
propensão dos indivíduos a ingressarem no mercado em busca dos meios de sua sobrevivência. [...] o movimento que faz com que a oferta potencial de trabalho - formada pelos indivíduos socialmente considerados aptos por sua idade -, se transforme em oferta efetiva de trabalho - formada pelos indivíduos economicamente ativos, estejam eles ocupados ou desempregados (Guimarães et al, 2013, s/p).
}

Desta forma, o cenário de redução de oportunidades de emprego nos 1990 não veio acompanhado de uma redução da centralidade do mercado de trabalho enquanto lócus provedor de (tentativa de) acesso à renda, o que se evidencia pela não redução das taxas de participação e de procura de emprego.

Já com a retomada do crescimento na segunda metade dos 2000, a fragilidade dos vínculos trouxe consigo a novidade do que, em alguma medida, poderíamos chamar de intensificação da incerteza ocupacional em contexto de assalariamento formal expandido, justamente porque caracterizado pela maior dificuldade dos indivíduos se estabelecerem de maneira estável no setor formal. Embora, como dito, esta instabilidade não seja propriamente uma novidade, chama atenção o fato de que, ao atingir patamares 
inusitadamente altos de assalariamento e formalização, vem acompanhada de uma imagem de inclusão de uma massa considerável de trabalhadores. Se esta inclusão não é lá o que se poderia esperar do ponto de vista de um projeto de desenvolvimento sustentado pela garantia de uma cesta de direitos e benefícios que historicamente havia acompanhado o contrato formal por tempo indeterminado, ou mesmo de estabilidade no emprego, ela não deixa de propiciar novas formas de inclusão que se expressam tanto no valor simbólico conferido ao "trabalho com carteira" (Machado da Silva, 1991), como no amplo acesso facultado ao crédito e a novos padrões de consumo.

Obviamente não estamos advogando a pertinência da noção de "nova classe media", mas tampouco estamos rejeitando o entendimento de que há novidades importantes na dinâmica do mercado brasileiro de trabalho. Queremos ressaltar, com isso, que a expansão que assistimos do assalariamento formal na ultima década se deu sobre um mercado de trabalho fortemente flexível e onde a relação contratual formalizada está longe de garantir uma posição estável, que traga consigo um horizonte certo de alternativas entre estar ou não estar no mercado. Mesmo com a inegável expansão da proteção social nas ultimas décadas - destacando-se aí a regulamentação do seguro desemprego em 1991, o inicio da operação do FAT em 1994, e o aumento da sua cobertura desde então -, os trabalhadores que transitam pelo mercado e fora dele alimentam as engrenagens da rotatividade sob a égide da expansão do assalariamento e do acesso (mesmo se restrito) a direitos. No que se refere à pobreza, como pretendemos mostrar no terceiro capitulo, essa institucionalidade tem contribuído para a incorporação de um número considerável de trabalhadores na base da pirâmide; e, mesmo se a maioria dos empregos gerados no período tenha sido de até 1,5 salários mínimos (Pochman, 2012), a forte valorização do seu valor base nos anos recentes, em conjunto com o padrão de empregos que se estabelecera, contribuíram decisivamente para a redução da pobreza ocorrida a partir da segunda metade da década de 2000.

As características da expansão recente do assalariamento distingue cabalmente o caso brasileiro do correlato "clássico" que observamos nos países de capitalismo avançado. Mesmo correndo o risco de uma extrema simplificação, pode-se dizer que nesses países houve uma certa sincronia no andamento dos processos de industrialização, de mercantilização da força de trabalho/assalariamento e de expansão da proteção social, o que Polanyi chama de um movimento de "autoproteção da sociedade" (Polanyi, 2000). 
Ou seja, a partir de uma atividade econômica moderna que se generalizava, mercantilizou-se a força de trabalho para, num momento posterior, desmercantilizá-la por meio da concessão de direitos que gradualmente se expandiram, consolidando um amplo regime de proteção social. As transformações que se abateram sobre esses países a partir da década de 1970 vieram acompanhadas de uma flexibilização das relações contratuais de trabalho e de novas (e mais exigentes) regras para o acesso aos serviços de welfare. Não por acaso, assistiu-se ao aumento das "novas" e "atípicas" formas de emprego e do número de "working poors" (Marx, 2007, Newman, 2006), justamente porque estranhos ao que se havia consolidado no decorrer dos chamados "trinta anos gloriosos" do século XX.

No Brasil, e em especial no estado de São Paulo, é verdade que o processo de expansão do assalariamento vinculado à industrialização se inicia na transição do século XIX para o XX (Barbosa, 2008) e se consolida gradativamente ao longo deste último. Mas o padrão é bastante distinto, como destacaremos a seguir.

\subsection{Notas sobre a construção institucional do mercado de trabalho no Brasil}

A efetiva construção institucional do mercado de trabalho e das políticas sociais a ele vinculadas coincide com o projeto desenvolvimentista que se iniciara a partir de 1930 e com um governo autoritário que expressava duas preocupações centrais: criar uma política a partir do ideal de equidade, sem que seus efeitos afetassem negativamente - e, ao contrario, viessem a contribuir para - o movimento da acumulação (Santos, 1979). Num processo de industrialização que começava a ganhar corpo, o contingente populacional urbano foi se incrementando e cedendo espaço a um novo modelo econômico que alterou, gradativamente, a dinâmica das forças sociais internas. Sob um regime de restrição de direitos civis e políticos, os diretos sociais e as políticas a ele associadas encontraram no mercado de trabalho formal sua via de acesso.

Foi a partir do traço corporativista e meritocrático, porque associado à ocupação e à contribuição a ela vinculada, que o governo autoritário estabeleceu os parâmetros de 
regulação do mercado de trabalho e suas fronteiras em relação ao todo social ${ }^{7}$. A Consolidação das Leis do Trabalho e da legislação sindical, entre fins dos anos 1930 e inicio dos 1940, tratou de assegurar vantagens trabalhistas e mínimos sociais cobrindo o reduzido espectro de trabalhadores urbanos e formalizados, ao mesmo tempo em que reduzia a capacidade efetiva de atuação dos sindicatos enquanto representantes legitimas da classe trabalhadora, ao transferir o conflito originário entre trabalho e capital para o interior da maquina burocrática estatal (Cardoso, 1999).

No plano político-institucional tinha lugar um acesso restrito às políticas de bem-estar, enquanto que, no plano econômico, ocorria um processo de industrialização que se mostrava insuficiente na absorção da força de trabalho nacional e na generalização da condição salarial no interior do mercado. Se nos países de economia avançada pode-se dizer que a proteção social se consolidou em relativa consonância com um modelo econômico capaz de absorver formalmente a maior parcela da força de trabalho, no Brasil o binômio "trabalho formal - proteção social" esteve longe de tal sincronia e, portanto, carente de se universalizar e garantir o acesso simultâneo à renda (via mercado de trabalho formal) e à proteção (via Estado).

A ideia de "inclusão controlada" de Santos (1979) aponta o caráter "regulado" da cidadania no Brasil a partir da década de $1930^{8}$. A "cidadania regulada (ou "ocupacional")", segundo o autor, diria respeito a um modelo de cidadania (e os direitos a ela associados) acoplada ao corporativismo, ou seja,

cujas raízes encontram-se [...] em um sistema de estratificação ocupacional, [...] definido por ordem legal. Em outras palavras, são cidadãos todos aqueles

\footnotetext{
${ }^{7}$ Ao longo dos anos 1930, uma série de regulamentações foram introduzidas no reduzido setor moderno e urbano da economia para mediar a relação capital-trabalho: repouso remunerado; regulamentação do trabalho de mulheres; proibição do trabalho de crianças e regulamentação do trabalho de menores; definição de um salário mínimo; estabilidade no emprego; condições de trabalho (segurança e higiene); regulamentação de insalubridade; regulamentação da sindicalização. Mais especificamente no campo da proteção social, são criados os primeiros Institutos de Aposentadorias e Pensões (IAPs) com a Lei Eloy Chaves, de 1923. Esta iniciativa é tomada, em geral, como a "gênese" da seguridade social no Brasil.

8 Não pretendemos aqui adentrar o debate que a idéia de "cidadania regulada" suscitou no meio acadêmico brasileiro, mas apenas salientar o caráter "corporativo" da forma como os direitos - em especial os sociais - foram constituídos a partir da década de 1930 no Brasil, e como tal perspectiva contribuiu para organizar o modo de se pensar, na academia, a relação entre os direitos, a proteção social e o mercado de trabalho. De fato, como afirma Reis (2000, p. 340), “o conceito de 'cidadania regulada', ao ser associado a palavras de conotação negativa como 'desigualdade' e 'estratificação', sugere claramente uma condição alternativa, supostamente 'normal' ou 'boa', em que a cidadania seria livre de regulação pelo Estado. Contudo, é patente que o desenvolvimento da cidadania envolve sempre, ao contrário, crescente regulação". Para a crítica completa, ver: Reis, 1991; 2000.
} 
membros da comunidade que se encontram localizados em qualquer uma das ocupações reconhecidas e definidas em lei. (Santos, 1979, p. 75).

Seriam, portanto, a regulamentação das profissões, o sindicato público e a carteira profissional os três parâmetros basilares da cidadania no Brasil, condicionando assim o sistema de estratificação baseado na estrutura ocupacional. Na medida em que o acesso aos serviços de proteção se encontrava vinculado à posse da Carteira de Trabalho e ao seu reconhecimento enquanto meio legítimo de garantia da cidadania, o que se observa é não apenas uma "dualidade" fundada nos aspectos tradicionais e modernos da estrutura produtiva brasileira mas, mais do que isso, uma dualidade entre aqueles que estão "dentro" e "fora" do escopo de atuação das políticas sociais. O mercado de trabalho se institucionaliza pela via da relação de trabalho formal, que fornece os componentes legais e simbólicos de sua estruturação.

O quadro teórico se clarifica contextualmente na medida em que, seguindo esta linha de raciocínio, Machado da Silva chama atenção para o fato de que tais processos representam uma deficiência histórica do Estado brasileiro em estabelecer respaldos institucionais e valores culturais na delimitação do que se poderia chamar de uma "oferta de trabalho" (Machado da Silva, 1991). Diferentemente do que se observa na maioria dos países capitalistas avançados, segundo este autor, a forma "inorgânica" da conversão do trabalho em trabalho assalariado deu-se num contexto de "ausência de suporte político-institucional para um conjunto claro e definido de posições fora do mercado socialmente reconhecidas [o que] torna o excedente uma massa amorfa de 'trabalhadores em disponibilidade"” (Machado da Silva, 1991, p. 3), de modo que toda a população se torna, em princípio, oferta de força de trabalho.

Dessa forma, seja do ponto de vista da forma de atuação do Estado, garantindo direitos que viabilizassem uma circulação regulada da população no mercado de trabalho, de um lado, seja pelo acesso a serviços de proteção, de outro, é interessante sublinhar justamente o caráter restrito desses "dois lados da mesma moeda" no Brasil. Quase que paradoxalmente, entretanto, o caráter "ocupacional" da cidadania parece ter criado uma

parte dura, nuclear, do mercado. Nestes casos, produziu-se legitimidade e garantiu-se a incorporação de trabalhadores ao preço de uma segmentação do mercado que não responde apenas às condições inerentes ao processo produtivo, e a torna muito mais rígida, porque protegida também por requisitos extra econômicos. (Machado da Silva, 1991, p. 5). 
Observa-se, nesse sentido, uma heterogeneidade interna do mercado de trabalho que, para além das próprias características estruturais do ponto de vista do sistema produtivo, encontra no plano da institucionalização dos direitos e na regulação do Estado os seus parâmetros fundadores. Ou seja, as fronteiras do mercado de trabalho adquirem um caráter profundamente ambíguo. Extremamente fluida nos limites à sua participação, porque carente de uma regulação ao seu ambiente externo; e, ao mesmo tempo, extremamente rígida do ponto de vista do acesso ao limitado escopo da proteção social, porque vinculado a um modelo contratual que estava longe de se generalizar. Consequentemente, são colocados limites à consolidação e universalização dos serviços de proteção social ao longo do século XX no Brasil, na medida em que estes próprios se encontravam estreitamente vinculados à forma como as posições sociais foram produzidas e legitimadas, seja do ponto de vista da hierarquia ocupacional, seja a partir das possibilidades de inserção no setor reconhecido institucionalmente - no "núcleo duro" do mercado de trabalho, como bem colocou Machado da Silva.

\begin{abstract}
É nessa matriz que sobretudo se esclarece o tipo de vínculo entre Estado e sociedade que os direitos sociais definiram. Tal como foram institucionalizados na sociedade brasileira, estabeleceram uma relação vertical com o Estado, que retribui na medida da retribuição de cada um, formalizando no mundo publico da lei uma matriz privada na qual as garantias contra a doença, a invalidez, a velhice, a orfandade dependem inteiramente da capacidade de cada um em conquistar o seu lugar no mercado de trabalho. (Telles, 2001, p. 25).
\end{abstract}

Mercado de trabalho, direitos e proteção social no Brasil parecem ter configurado historicamente um contínuo disforme e obscuro que acabaram por fornecer os meios institucionais para que se fundassem - e difundissem - categorias como "marginalidade" e "informalidade", que longe de se tratarem de meros "rótulos" para uma condição de "inferioridade social" (do ponto de vista de rendimentos salariais e instabilidade na ocupação), comportavam o aspecto de exclusão no acesso aos meios legais de garantias de direitos e, consequentemente, no acesso aos serviços de proteção (Santos, 1979).

Direitos que recriam desigualdades, pela sua vinculação profissional, são também direitos que não se universalizam, sobrepondo às diferenças sociais uma outra clivagem que transforma em "não-cidadãos" os que escapam às regras do contrato. Esses são os "não-iguais", os que não estão credenciados à existência cívica justamente porque privados de qualificação para 0 trabalho. São os pobres, figura clássica da destituição. Para eles, foi reservado o espaço da assistência social, cujo objetivo não é elevar as condições de vida, mas minorar as desgraças e ajudar a sobreviver na miséria. (Telles, 2001, p. 26). 
É bem certo que essa estrutura se ampliou gradativamente e se modificou já no curso dos governos militares. A previdência foi expandida aos segmentos rurais, domésticas e autônomos foram incorporados, foi criada a Renda Mensal Vitalícia, dentre outras iniciativas ${ }^{9}$. Posteriormente, com a Constituição de 1988, que veio coroar uma série de direitos sociais ${ }^{10}$ e trabalhistas, como o direito de greve, liberdade para a criação de sindicatos sem a tutela do estado, negociação direta entre sindicatos e empregadores, redução da jornada de trabalho para 44 horas, seguro desemprego (que viria a ser regulado em 1991), licença maternidade/paternidade (Cardoso, 1999).

A questão que interessa no momento, entretanto, não é tanto o que se poderia chamar de uma "evolução do Estado de Bem Estar no Brasil" no sentido amplo do termo, mas sim o legado histórico-institucional fornecido pelos parâmetros estruturadores do processo de assalariamento e como a proteção social a este se vinculou. Nesse sentido, mesmo com a inquestionável e progressiva sedimentação das fronteiras do mercado de trabalho e a delimitação regulatória de quem está "dentro" ou "fora" ao longo de todo o século XX e no inicio deste, reiteramos o que fora antes sublinhado nas palavras de Machado da Silva: a inorganicidade da conversão de uma potencial oferta de trabalho para uma efetiva oferta de trabalho. Para que haja um processo de "desmercantilização" do trabalho é necessário que, antes de tudo, haja sua mercantilização. Vale dizer, o trabalho tem que ser convertido em mercadoria (e por isso mesmo passível de ser comprado e vendido no mercado) e, em momento seguinte, seu uso e reprodução devem ser regulados do ponto de vista do grau em que os indivíduos necessitam, de fato, vendê-lo no mercado de trabalho para atingir níveis mínimos de subsistência e de (re) produção do seu bem-estar.

\footnotetext{
${ }^{9}$ É bastante vasta a literatura que trata da expansão da proteção social ao longo do período militar. Para mais detalhes ver: Draibe (2004); Fagnani (1989) Kerstenetzky (2012).

${ }^{10}$ Dentre os marcos legais instituídos no campo da proteção social após 1988, podemos destacar: i) um certo afrouxamento do vínculo contributivo como princípio estruturante do sistema; ii) a universalização do acesso e a expansão da cobertura; iii) a recuperação e redefinição de patamares mínimos dos valores dos benefícios sociais; iv) maior comprometimento do Estado com o sistema, projetando um maior grau de provisão estatal pública de bens e serviços sociais; dentre outros. Cabe ainda uma referencia à universalização do acesso à saúde por meio do SUS e a expansão crescente do sistema educacional. (Draibe, 2002).

${ }^{11}$ No capitulo seguinte apresentaremos com mais detalhes o debate relativo à "desmercantilização". De todo modo adiantamos, seguindo Esping-Andersen (1990), que a "desmercantilização" diz respeito ao grau em que indivíduos e famílias podem garantir um nível de vida socialmente aceito independentemente da participação no mercado.
} 
Mas se esta inorganicidade deixou sua marca histórica, devemos ir devagar com o andor para não minimizar a contínua e ininterrupta expansão do assalariamento formal que tivera lugar no período de expansão até 1980. Nesse sentido, retomamos o argumento de Guimarães (2011) de que o modelo brasileiro mostrou-se capaz de estabelecer este ponto de não retorno que prende o trabalhador ao mercado de trabalho pela venda da força de trabalho, num crescente processo de "mercantilização" da oferta potencial de trabalho. Todavia, tal processo se deu sobre frágeis bases institucionais no que concerne à proteção social, de modo que o distintivo é que durante muito tempo, por quase 60 anos, o mercado de trabalho formal foi o único meio de acesso à proteção social, relegando aos não inseridos a necessidade de uma constante busca de obtenção de meios de subsistência mediante atividades que lhes negavam o passaporte da cidadania, justamente porque o Estado não lhes garantia mínimos sociais que “dispensassem”, por assim dizer, sua participação no mercado de trabalho.

Tal vinculação é recorrentemente salientada nos estudos que buscam identificar o "modelo" do regime de proteção social no Brasil e de outros países da América Latina. Para nos atermos apenas à relação entre o regime de proteção e o mercado de trabalho, Filgueira (1999) sublinha a exclusão histórica de uma boa parte da força de trabalho aos serviços de proteção, o que o leva a classificar o Brasil, ao lado do México, como um modelo dual, caracterizado pelo "universalismo estratificado" nas áreas urbanas e por ser excludente no que respeita às áreas rurais. Franzoni (2008) também argumenta em acordo com os que reconhecem um progressivo processo de mercantilização; salienta, entretanto, que o movimento contrário, qual seja, o de "desmercantilização", ao ter estado historicamente vinculado ao mercado formal, acabou por relegar aos próprios indivíduos a responsabilidade de lidar com os riscos provenientes da (não) inclusão no mercado de trabalho ${ }^{12}$.

Por outro lado, é possível argumentar que com o estabelecimento dos novos direitos assegurados pela Constituição de 1988, os anos 1990 guardam uma peculiaridade do

\footnotetext{
12 Para além destes, há uma série de estudos que buscam classificar tipologicamente os regimes de proteção social nos países em desenvolvimento (Filgueira, 1998; Martínez-Franzoni, 2008; Barrientos, 2004; Huber e Stephens, 2001). A despeito das diferenças de metodologias adotadas e do escopo temporal, o traço meritocrático que historicamente vincula a proteção social ao mercado de trabalho formal, tendo como pano de fundo a "peculiaridade" do movimento de expansão e não generalização do assalariamento em contraposição aos países desenvolvidos, é sempre uma constante.
} 
que poderíamos chamar de uma sorte de duplo movimento. Ao mesmo tempo em que acenava com uma "Constituição cidadã", recentemente instituída e farta em avanços na agenda social, um cenário de profundas transformações econômicas promovia uma redução dos direitos associados ao trabalho a partir de meados da década, como já vimos. Se, primeiramente, assistiu-se à deterioração do mercado de trabalho na esteira da sua "flexibilização", com o aumento da informalidade e da pobreza, foi justamente sobre tais parâmetros que o mercado se revigorou na segunda parte dos anos 2000 .

Nesse sentido, o que, nos países capitalistas mais avançados é ou foi tomado como uma perda de direitos e como um dos sintomas da "crise do Welfare State", aqui tem sido, nos anos recentes, a porta de entrada de milhões de trabalhadores ao mercado formal de trabalho, muito embora sem a relativa estabilidade de outrora. E mesmo que também tenha significado uma perda de direitos do ponto de vista da antiga institucionalidade criada com a CLT no que concerne à regulação dos contratos, é justamente sobre esta nova institucionalidade, estabelecida em meados dos anos 1990 que a expansão recente tem ocorrido ${ }^{13}$ e, especialmente por ter estado associada a uma política de valorização do salário mínimo, vem contribuindo para a redução da pobreza. Tal redução, entretanto, também se deve à evolução da cobertura da proteção social na base da pirâmide, ponto em que nos deteremos a seguir a fim de elucidar melhor o caminho dessa expansão institucional, antes que os seus efeitos, já que fazê-lo ultrapassaria, em muito, o escopo deste estudo.

\subsection{Evolução recente das políticas sociais de combate à pobreza}

Apesar do marco legal universalista de direitos sociais que se estabelecera com a Constituição de 1988, a esfera da política social perdeu centralidade na agenda nos primeiros anos do governo democrático em virtude da prioridade concebida às políticas de ajuste fiscal (Cohn, 1995). Esta centralidade só viria a ser retomada em meados dos 1990, no governo de Fernando Henrique Cardoso, em especial com os investimentos em

\footnotetext{
${ }^{13}$ Cabe uma breve ressalta para evitar mal entendidos. Em nenhum momento está se advogando aqui a necessidade ou a virtuosidade de relações de trabalho "flexíveis". Estamos apenas verificando que foi sobre este tipo de regulação que se deu a expansão recente. Responder se o mesmo teria ocorrido num contexto "menos ou mais flexível" não é nosso objetivo.
} 
educação básica e saúde e com a ampliação dos programas de combate à pobreza. Notese que esse movimento se faz concomitante com o outro, acima relatado, de flexibilização das regras contratuais (e dos direitos) no mercado de trabalho.

Em 1996 o Governo Federal criou um dos primeiros programas de transferência condicionada de renda a nível nacional, o Programa de Erradicação do Trabalho Infantil (PETI), que consistia na transferência de renda às famílias cujas crianças menores de 16 anos trabalhavam ou corriam o risco de trabalhar. No ano 2000 foi criado o Projeto Alvorada, um conjunto de programas federais nas áreas da educação, saúde e geração de renda, com prioridade para implementação nos municípios com mais baixo IDH. Em 2001 e 2002 o projeto foi transformado na "Rede Social Brasileira de Proteção Social" que, além da previdência rural e dos programas não contributivos da assistência social, comportava uma série de programas de transferência de renda, com destaque para o Bolsa-Escola.

Na busca de solução para a sobreposição dos programas e de coordenação de informação dos potenciais beneficiários, ao final do governo foi criado o Cadastro Único de Programas Sociais (CadÚnico), que não teve tempo de ser aprimorado ainda na gestão de Fernando Henrique Cardoso. Segundo Soares e Sátyro (2009), o final do governo FHC foi marcado por um cenário de relativo caos no campo da assistência social, em função tanto da dificuldade de coordenação dos inúmeros programas que formavam a Rede Social Brasileira de Proteção Social, como pela conturbada relação entre os três entes federativos na implementação e gestão dos programas. Por outro lado, a despeito das inúmeras imperfeições, o país avançara na construção de um sistema nacional de assistência social, ganhando destaque uma série de programas de transferência monetária que posteriormente foram unificados pelo Programa Bolsa Família (Kerstenetzky, 2012).

A partir de 2003, o governo de Luiz Inácio Lula da Silva seguiu a tendência iniciada nos anos anteriores, mas concedendo maior prioridade à constituição do sistema de assistência social. O processo de institucionalização da política de assistência social, iniciado nos anos 1990 por meio da Lei Orgânica da Assistência Social (LOAS) e da criação da Política Nacional de Assistência Social (PNAS), se consolida com o Sistema Único da Assistência Social (SUAS) em 2005. 
O SUAS estabelece as bases e as normativas para a produção da proteção social, bem como a arquitetura da provisão de serviços socioassistenciais, definindo financiamento, critérios de partilha de recursos, protocolos e instruções normativas para a implementação do sistema com a participação dos diferentes entes federativos. Quanto à concepção que sustenta a estratégia de intervenção, o SUAS implantou uma nova engenharia operacional que parte de uma distinção entre dois níveis de atenção: a Proteção Social Básica (baixa complexidade) e a Proteção Social Especial (média e alta complexidade), para atender a diferentes situações de vulnerabilidade.

É no interior desta arquitetura institucional que se encontra atualmente o Programa Bolsa Família, que constitui hoje, junto com o Benefício de Prestação Continuada $(\mathrm{BPC})^{14}$, a principal iniciativa de combate à pobreza no âmbito da proteção social não contributiva. Ele beneficia atualmente cerca de 13,5 milhões de famílias, recobrindo todo o território nacional. O Programa transfere uma renda básica a famílias consideradas "pobres" ou "extremamente pobres"," sob a condição do cumprimento de condicionalidades por parte das famílias beneficiadas no âmbito da educação e da saúde, de sorte a ampliar o acesso da população a esses serviços básicos, contribuindo para o rompimento de um ciclo intergeracional de pobreza. Uma das novidades na gestão do programa foi o aprimoramento do Cadastro Único, que constitui hoje uma ferramenta chave na elaboração, gestão, implementação e avaliação de Programas sociais do governo federal. O CadÚnico contém informações detalhadas sobre as famílias com renda per capita de até $1 / 2$ salário mínimo, como escolaridade dos membros, condição laboral, características do domicílio, dentre outras. Em tese, todas as famílias brasileiras com renda per capita de até meio salário mínimo devem estar ali

\footnotetext{
${ }^{14}$ Este beneficio incorporou um antigo benefício de renda mensal vitalícia - RMV (benefício de $1 / 2$ salário mínimo para idosos com mais de 70 anos e inválidos que tivessem contribuído 12 meses) e o ampliou em termos de cobertura e critérios de elegibilidade O BPC elevou o benefício para 1 salário mínimo, além de permitir a inclusão de portadores de deficiências graves, sem passagem pelo mercado de trabalho. A idade mínima para idosos se tornarem elegíveis foi alterada de 70 para 67 anos em 1998, e para 65 anos em 2003. Ao ser extinto, em 1995, o RMV atendia a 900 mil beneficiários e em 2004 o BPC já superava a marca de 2 milhões e em 2011 tinha cerca de 3,5 milhões de beneficiários, significando uma importante política de garantia de renda para pessoas em situação de vulnerabilidade (idosos e deficientes com renda per capita inferior a $1 / 4 \mathrm{SM}$ ).

${ }^{15}$ Famílias "extremamente pobres": renda mensal per capita de até $\mathrm{R} \$ 70,00$. Famílias pobres: renda mensal per capita entre $\mathrm{R} \$ 70,01$ e $\mathrm{R} \$ 140,00$.
} 
cadastradas e a cada dois anos o governo realiza uma atualização da situação cadastral das famílias.

Atualmente, o Programa Bolsa Família integra um dos eixos do Programa Brasil Sem Miséria (PBSM), criado no ano de 2011 pelo Governo Federal com o objetivo de erradicar a extrema pobreza no Brasil. Além da transferência de renda, o PBSM tem ainda como eixos principais os assim-chamados "Acesso a serviços públicos” (nas áreas de educação, saúde, assistência social, saneamento e energia elétrica) e "Inclusão produtiva”. O principal objetivo do Programa Bolsa Família é o alívio imediato e o rompimento de um ciclo intergeracional da pobreza através de transferências monetárias às famílias que são classificadas como "pobres" ou "extremamente pobres". As condicionalidades ${ }^{16}$ ocupam um lugar estratégico no Programa, sendo entendidas como contrapartidas das famílias de modo a ampliar as capacidades dos indivíduos no médio e longo prazo.

São inúmeros os estudos que buscam identificam como a expansão da proteção social na base da pirâmide - e não apenas do Programa Bolsa Família - contribuiu para a redução da pobreza e para o ciclo de crescimento recente, num movimento de "efeitos multiplicadores" (Foguel e Barros, 2008; Teixeira, 2008; Leichsenring, 2010; Neto, 2010; Soares et al, 2010; Kerstenetzky, 2012; dentre outros). Não cabe aqui ir mais adiante nas considerações sobre esses efeitos, já que o objetivo dessa seção foi apenas o de sistematizar, para que tenhamos claro em momento posterior, esse movimento de construção institucional da proteção social e das políticas de combate à pobreza, e sua especificidade no caso brasileiro, onde se fez em concomitância com a expansão do assalariamento formalmente protegido, num contexto de crescimento econômico e de valorização do salário mínimo, mas sob a redução de direitos dos que acorriam ao mercado protegido que se expandiu maiormente sob a égide da flexibilização das regras contratuais.

\footnotetext{
${ }^{16}$ As condicionalidades envolvem: frequência escolar mínima de $85 \%$ para crianças e adolescentes entre 6 e 15 anos; frequência escolar mínima de $75 \%$ para adolescentes entre 16 e 17 anos; acompanhamento nutricional para crianças de 0 a 6 anos; realização de pré-natal para as mulheres grávidas e acompanhamento do calendário vacinal para crianças de 0 a 6 anos. Na área de assistência social, crianças e adolescentes com até 15 anos em risco ou retiradas do trabalho infantil pelo Programa de Erradicação do Trabalho Infantil (PETI) devem participar dos Serviços de Convivência e Fortalecimento de Vínculos (SCFV) do PETI e obter frequência mínima de $85 \%$ da carga horária mensal.
} 
Isso posto, convém retornar à temática das interpretações acerca da pobreza, a fim de apresentar brevemente como esse debate também se renovou ao longo dos anos 1990 e 2000, pari passu com as transformações econômicas e sociais que perpassaram essas duas décadas. Longe de pretender retomar o assunto do ponto de vista dos debates acerca da "questão social", tema já bem trabalhado por outros autores (Kowarick, 2003; Moya, 2003), nos interessa apresentar um fio interpretativo sobre a questão dos elos entre pobreza e mercado de trabalho, que buscaremos assentar em alguns desenvolvimentos teóricos que nos permitiram erigir a nossa proposta de estudo e as análises que apresentaremos mais à frente.

\subsection{Novas perspectivas sobre pobreza e trabalho}

Quando pensamos na temática relativa à pobreza e mercado de trabalho na América Latina, os temas da marginalidade e informalidade são certamente um marco central de localização do debate. Embora não seja nosso objetivo retomá-lo em seus meandros, ao modo de uma história intelectual desse campo, cabe aqui situá-los brevemente.

Marginalidade e informalidade não foram propriamente teorias sobre a pobreza e acredito que seja um reducionismo pensá-las sob este prisma. Foram e são concepções que se estabeleceram a partir da necessidade de se compreender os processos de desenvolvimento elou modernização da sociedade latinoamericana, incluídos aí também os seus aspectos políticos, notadamente aqueles relativos às possibilidades de constituição e fortalecimento da classe trabalhadora. O que estava em jogo, muito mais que diagnosticar a condição de privação dos ditos "pobres", era enquadrá-los no interior de uma estrutura econômica e social que se mostrava excludente (ou deficiente) do ponto de vista de sua incorporação no processo produtivo a partir da condição assalariada e que, justamente por isso, lhe negava o passaporte à "cidadania ocupacional" tal como esta fora estabelecida a partir da década de 1930 (Santos, 1979).

Seja nas versões ancoradas na teoria da modernização ou naquelas de cunho mais dependentistas, o "setor marginal" era visto como o resultado de um processo que 
decorria de formas peculiares de inserção no sistema produtivo, disfuncionais (Nun, 2003) ou funcionais (Kowarick, 1975) ao modelo de acumulação vigente ${ }^{17}$.

Concomitantemente, o conceito de "setor informal" ganha destaque como categoria para se compreender modos de inserção no mercado de trabalho não marcados nem pelo assalariamento quanto por contratos formais. Em trabalho seminal de 1971, Machado da Silva já mostrava como uma das distinções entre os dois setores residia na existência da firma juridicamente reconhecida em oposição ao indivíduo/família enquanto agente econômico e sem nenhum aporte jurídico. Enquanto aqueles que se encontram ocupados no primeiro setor são "empregados" no sentido estrito do termo, vendendo sua força de trabalho a apenas um empregador, os que se situam no segundo têm "vários patrões" (mais exatamente, clientes), o que lhes coloca sempre em uma situação de maior instabilidade, do ponto de vista da continuidade do trabalho, e de maior flexibilidade, no que se refere ao preço pelo qual a força de trabalho é vendida. Mas, mais importante que isso e mesmo do que a "caracterização geral" 18 desse setor, seus traços distintivos seriam, por um lado, a abismal heterogeneidade interna e por outro, e muito especialmente, aquilo que ele não era, o que lhe faltava, a saber, a regulação resultante de uma relação contratual de trabalho, o seu oposto "formal" (Machado da Silva, 2003).

A despeito das inúmeras polemicas e variações que os temas engendraram, tanto as noções de "setor informal" quanto "marginal" surgiram dos desafios de se compreender o desconcertante atraso da modernidade (para os intérpretes que forjaram argumentos mais lineares) e a lógica (deficiente) subjacente ao binômio "industrialização/ assalariamento" (Machado da Silva, ibid).

No que concerne aos nossos interesses, como viemos discutindo, a questão do processo de expansão do assalariamento tem um papel central na discussão e independentemente das causas apresentadas pelos diferentes modelos interpretativos é na ausência de um movimento linear e cumulativo que compreendesse a mercantilização da força de trabalho via assalariamento formal, a sua proteção e, finalmente, a consolidação de uma cidadania universal, que se encontra uma

\footnotetext{
${ }^{17}$ Não cabe aqui revisitar este amplo debate. Para mais detalhes ver: Kowarick (2003); Moya (2003).

${ }^{18}$ De um ponto de vista abrangente, o setor se caracterizaria pela facilidade de inserção dos agentes econômicos, utilização de tecnologia simples, baixa qualificação da mão de obra, unidades de produção de tamanho reduzido e possibilidade de coexistência de diferentes relações de produção.
} 
especificidade fundamental à nossa trajetória e em que se sustenta o argumento que pretendemos desenvolver.

Se marginalidade e informalidade, no Brasil e na América Latina, são pistas significativas para entendermos esse substrato, nos países centrais é justamente o movimento de enfraquecimento da condição salarial, estruturada em torno do trinômio Fordismo/Welfare State/Cidadania que animou o debate sobre as novas configurações da relação entre pobreza e trabalho a partir da década de 1980. Seja na tradição republicana francesa ou na individualista americana de enfrentamento da "questão social" (Kowarick, 2003), o que se destaca, e que nos interessa sublinhar, é a fragilização da, até então, robusta combinação entre trabalho assalariado e proteção social que se estabelecera em especial ao longo dos chamados "trinta anos gloriosos". Não por acaso, a literatura tratou de focalizar a sua atenção nos "inúteis para o mundo" (Castel, 1998), nos “desqualificados” (Paugam, 2003), na underclass (Wilson, 1987) e tantos outros termos que marcam o tom desse debate. Do ponto de vista da relação entre pobreza e trabalho, essas pessoas ou grupos compunham justamente aqueles que se haviam se tornado relativamente "desnecessários" do ponto de vista do sistema econômico, vistas as transformações que perpassaram o capitalismo nos países desenvolvidos a partir de meados da década de 1970.

Dessas transformações e da sua relação com os sistemas de proteção social trataremos com mais cuidado no capitulo seguinte. Por agora, convém salientar que essas concepções que diagnosticaram o surgimento de uma "nova pobreza" se encontram alicerçadas justamente sobre as transformações no mundo do trabalho em sociedades onde o assalariamento se fizera a norma. E por norma entende-se aqui mais do que a sua generalização, no sentido estrito do termo. Significa o normal, isso é, o que se assenta numa estrutura de normatividade que fornece os meios simbólicos e institucionais de integração social.

Para melhor explorar esse ponto, vamos nos deter rapidamente sobre dois autores que tiveram uma ampla repercussão no debate brasileiro. Ao tratar da "crise da sociedade salarial", uma das preocupações de Robert Castel está em fornecer um quadro conceitual e historicamente dinâmico a partir do qual poder-se-ia observar as possibilidades e os limites de manutenção e coesão do tecido social. Tomando como 
exemplo suas "quatro zonas" ${ }^{19}$ provenientes de dois eixos analíticos (econômico e social), notamos que é justamente uma situação de emprego estável (portanto protegido) e relações sociais densas (sociabilidade primária, família, vizinhança, etc.) que se caracteriza pela zona de integração. No extremo oposto, "desfiliação", em que à perda do emprego se soma o enfraquecimento das relações forjadas no cotidiano do trabalho, do bairro, dos sindicatos, etc. O cenário criado pelos anos 1980 seria, para Castel, marcado justamente pela desarticulação da sociabilidade centrada no trabalho assalariado e na vida comunitária.

Avançando nessa direção, Paugam (2003) analisa o fenômeno da "desqualificação social" na sociedade francesa. $\mathrm{O}$ autor diferencia três grupos que vivem esse processo e identifica diferentes formas de negociação do status de desempregado e assistido por programas de welfare. O primeiro - os "fragilizados" - são aqueles que vivem recentemente uma situação de vulnerabilidade, sem emprego e renda, e que resistem em ser incorporados aos programas de proteção social. O segundo - os "assistidos" - já fazem parte e são até dependentes dos programas, encontrando-se em uma situação de resignação frente à sua condição social. E por último - os "marginalizados" - que não se encontram mais sob a assistência governamental, constituindo o último escalão da desqualificação social. A “desqualificação social” é, assim, entendida como um processo de marginalização. Mas uma marginalização daqueles que, em determinado momento, haviam se encontrado numa situação de "plenamente" integrados.

A crise da sociedade salarial nos países desenvolvidos, portanto, reside num processo histórico-social de vulnerabilização, no qual - e isso é, a nosso juízo, o mais importante a atentar - a integração via assalariamento/proteção é condição ex ante para a sua existência. Kowarick sintetiza bem o argumento ao ressaltar que a questão social colocada nos termos da crise da sociedade salarial

é fruto de um percorrer histórico que leva à consolidação de direitos coletivos, relativos à seguridade social e ao trabalho, enfim à constituição de

\footnotetext{
${ }^{19}$ As dimensões econômica (estabilidade e regularidade no trabalho) e social (redes de sociabilidade primária - família, vizinhança e comunidade) configuram "quatro zonas": i) integração: situação de emprego estável e relações sociais densas; ii) vulnerabilidade: fragilização das condições laborais e relacionais; iii) assistência: recebimento de benefícios públicos que evitam um "desligamento" econômico e social; iv) desfiliação, que se refere a uma situação de desemprego prolongado e fragilização dos laços sociais.
} 
um campo legitimo e legal de reivindicações em que os opositores se chocam nos conflitos e aceitam as regras de sua negociação (Kowarick, 2003, p. 59).

Isso nos permite ressaltar, do ponto de vista das interpretações sobre pobreza e trabalho, a dissonância entre aquilo que foi concebido como "crise da sociedade salarial" alhures e o que historicamente vivenciamos em terreno brasileiro. As próprias concepções acerca da marginalidade e informalidade, como ressaltamos, traziam à luz o caráter modelador do fenômeno, resultante da dinâmica do capitalismo terceiromundista, tornando essas duas categorias fortemente tributárias, no caso brasileiro, do marco institucional de privação de direitos sociais que se decorrera do modelo de cidadania ocupacional. Os setores marginal e informal nunca foram concebidos como resultados de um processo de esfacelamento do tecido social. Dessa forma, estão longe de se constituir como decorrentes de uma crise do assalariamento: sua "existência empírica" residia justamente na interação entre a ausência vigorosa desse processo e o limitado escopo das instituições na delimitação regulatória da proteção social enquanto conformadoras dos que "estão dentro" e dos que "estão fora" (mas protegidos) do mercado (Machado da Silva, 1991; Santos, 1979). A condição de integração via assalariamento era o ponto de chegada vislumbrado, antes que o ponto de partida tal como pode ser observado na "crise da sociedade salarial".

Por outro lado, em relação à pobreza, já nos anos 1980 um importante e significativo movimento de deslizamento de significado tinha tido lugar no Brasil: "população pobre" torna-se sinônimo de "população de baixa renda", vale dizer, aqueles que são incapazes de garantir e obter no mercado o provento mínimo para sua sobrevivência. Tendo o salário mínimo como parâmetro, passa a ser possível distinguir os potenciais elegíveis, bem como identificar grupos diferenciados no interior da "população de baixa renda". Mais uma vez, reaparece a importância do continuado processo de mercantilização do trabalho e de expansão do assalariamento formal, na medida em que, como argumenta Guimarães, (2011), o salário mínimo (e a carteira) deixam de ser apenas um valor, uma meta simbólica (como assinalado por Wanderley G. dos Santos e Machado da Silva), e passam a ser termômetros, tendo um efeito (pelo seu valor) para calibrar os termos monetários da venda do trabalho no mercado em geral, e podendo tornar-se, também, em parâmetros para a própria política pública de proteção. 
Ou seja, mesmo que não se possa efetivamente reconhecer um movimento de plena integração via assalariamento, ao modo do fordismo dos países centrais, destacamos este ponto de não retorno de mercantilização da força de trabalho que havia sido alcançado. E é justamente em virtude desse processo que a crise que se abateu sobre a economia e o mercado de trabalho brasileiros a partir da década de 1990 trouxe consigo o diagnóstico do (e chegou a ser lida por muitos como) desassalariamento; afinal, e pela primeira vez em quase 50 anos de expansão da atividade econômica, vivíamos uma inflexão negativa nesse processo.

É partindo dessas transformações que a temática da "exclusão social" foi prontamente incorporada no meio intelectual brasileiro, embora com linhagens interpretativas distintas (Moya, 2003). Não cabe retomar esse debate ${ }^{20}$ e discutir a pertinência ou não da sua atualidade, mas não deixa de ser evidente que o que o motivou, em boa parte, foram as consequências associadas às novas formas de privação e sua articulação entre as transformações econômicas e do mercado de trabalho ${ }^{21}$.

Tomo emprestados dois autores relativamente críticos à noção de exclusão tal como foi concebida no contexto brasileiro para posteriormente vincular essas ideias ao que foi afirmado acima. Martins (1997), por exemplo, questiona o modo eminentemente normativo e impreciso pelo qual o conceito de exclusão social se difundiu no Brasil, tal como um "deus/demônio" capaz de tudo explicar e ignorando o fato de que os ditos "excluídos" na verdade são empurrados para dentro de um processo de dominação que os tornam simples "reprodutores mecânicos do sistema econômico, reprodutores que não reivindicam nem protestam em face de privações, injustiças e carências" (Martins, 1997, p. 17). Desta forma, o que haveria de diferente nesse novo contexto em relação a outros processos históricos de expulsão/êxodo de alguns segmentos populacionais para sua subsequente incorporação em uma dinâmica social distinta (o exemplo clássico é a

\footnotetext{
${ }^{20}$ Para uma boa contribuição de como o tema da exclusão social foi tratado no Brasil, ver: Moya (2003).

${ }^{21}$ Queiroz (2005), por exemplo, afirma que a pobreza urbana contemporânea não se define apenas pelas carências relativas ou absolutas de determinados segmentos sociais que se encontram nas posições inferiores do sistema de estratificação, mas também e, principalmente, porque são esses grupos os mais vulneráveis aos novos mecanismos de marginalização e exclusão gerados pelo capitalismo financeiro. Semelhante perspectiva pode ser encontrada em Ziccardi (2008). Postura diferente é encontrada em Faria (1994), que retoma a questão contextual para afirmar que o conceito de exclusão transmite ideias como falta de integração, dualização e diferença cultural, fenômenos pouco condizentes com as situações latinoamericanas de pobreza e privação. Seria mais apropriado, nesse sentido, tratar do tema a partir da noção de "padrão específico de integração na divisão social do trabalho", tal como a tradição latino-americana já havia sublinhado.
} 
transição da população rural para o meio urbano), é justamente o esfacelamento das expectativas de incorporação plena numa ordem econômico-social que lhes nega esta trajetória $^{22}$.

Uma postura semelhante é desenvolvida por Lucio Kowarick que, mesmo fazendo ressalvas com relação ao uso indiscriminado da noção de desfiliação de Castel discutida acima, sugere ser pertinente utilizá-la a partir da chave do "desenraizamento" social e econômico. Se não é um desenraizamento do ponto de vista da sociedade salarial, argumenta, é o desenraizamento do trabalho formal, expresso no aumento na fatia de desempregados e empregos precários ${ }^{23}$. O que está em jogo, mais uma vez, é a transição entre o ponto de saída e o ponto de chegada, na medida em que implica um caminho de distintas perdas: de qualidade da moradia, de acirramento do desemprego e de precarização do trabalho. Nesse sentido, o processo estaria longe de designar "exclusão", se esta significar processo de separação e banimento, como num desligamento econômico e social. Antes disso, implicaria na perda da institucionalidade de um horizonte estável e estabelecido como pano de fundo do mercado de trabalho "precário".

Acreditamos ser possível traçar, nesse sentido, um paralelo entre a insegurança e a instabilidade diagnosticadas nos percursos no mercado de trabalho tal como ressaltado por Guimarães $(2006$; 2010) e Cardoso (2010) e a forma como os autores acima traduziram-na sob a ótica da pobreza (ou da vulnerabilidade socioeconômica e civil, nas palavras de Kowarick). Tais aspectos também aparecem, até certo ponto, nas leituras das trajetórias urbanas vivenciadas nas tramas da metrópole paulistana no contexto mais recente (Telles e Cabanes, 2006; Cabannes et al 2011). Munidos de uma vasta informação etnográfica, estes estudos colocam em evidencia como as novas configurações e a inserção da metrópole nos circuitos do capital globalizado acabam por abrir espaços fronteiriços que re-significam a sociabilidade construída a partir do trabalho, reduzindo sua centralidade enquanto parâmetro estruturador da ação coletiva e

\footnotetext{
${ }^{22}$ Nas palavras do autor: "A sociedade moderna está criando uma grande massa de população sobrante que tem pouca chance de ser de fato reincluída nos padrões atuais de desenvolvimento econômico. Em outras palavras, o período de passagem do momento da exclusão está se transformando num modo de vida, está se tornando mais do que um período transitório" (Martins, 1997, p. 33).

${ }^{23}$ Importante ressaltar que esse argumento de Kowarick veio à luz em 2003, ou seja, foi formulado ainda num momento de elevado desemprego e informalidade.
} 
dos seus significados subjacentes. Nesse ínterim, o próprio "setor informal" se reconfigura a partir de uma teia de relações que tornam cada vez mais fluidas as fronteiras entre o legal e o ilegal, o licito e o ilícito, moldando trajetórias, mais das vezes localizadas nas franjas da institucionalidade das dinâmicas de poder e da regulação do Estado (Cabbanes et al, 2011; Freire, 2011, Hirata, 2011).

Esta fluidez das fronteiras é também identificada por Cardoso (2013) no tocante ao setor informal do mercado de trabalho e do percurso ocupacional dos trabalhadores. No que chama de uma "zona de coordenação rarefeita", mas não menos integrada aos circuitos do fluxo do capital global, o autor mostra que antes que um setor apartado do ponto de vista da inserção no mercado de trabalho, trata-se de um constante espaço de transição para aqueles que se desligam periodicamente do setor formal, marcado pela densidade das relações sociais que lhe garantem os mecanismos de coordenação.

Assim, e retomando, ao longo dos anos 1990, pareciam diminuir as possibilidades de (re) inserção no mercado de trabalho protegido, trazendo interpretações no que tange ao esgarçamento do tecido social e às trajetórias individuais e familiares. A dinâmica econômica, com os saltos de incorporação tecnológica e de produtividade num contexto de relações de trabalho "mais flexíveis", havia tornado redundante um amplo contingente de trabalhadores porque estes se mostravam desnecessários do ponto de vista das novas dinâmicas produtivas. $\mathrm{O}$ "desenraizamento" presente no argumento de Kowarick é, em boa medida, fruto desse processo.

Mesmo com a continuidade e até intensificação da instabilidade ocupacional, como ressalta Cardoso (2013), o crescimento via assalariamento formal ocorrido na segunda metade dos 2000, conquanto ainda marcado pela "flexibilidade" e elevada rotatividade no mercado de trabalho, acabou por incluir um sem numero de indivíduos outrora privados dessa condição. Conjuntamente, observamos uma elevada ampliação de acesso ao crédito e das políticas de transferência de renda na base da pirâmide, fazendo crescer o percentual de famílias que hoje compõe a "Classe C" e reduzindo significativamente o número de "pobres". Se este cenário é sustentável no longo prazo, ainda é uma questão em aberto, ainda mais se tivermos em mente as ressalvas de Cardoso (2013) de que o mercado de trabalho ainda se mostra insuficiente em prover posições estáveis para a maioria dos trabalhadores. 
Se o paralelo que tentamos traçar entre os diagnósticos do mercado de trabalho ressaltados por Guimarães e Cardoso - e as tematizações sobre pobreza que enfatizaram a ruptura de trajetórias de horizontes estáveis na esteira da "reestruturação produtiva" como em Kowarick, Martins, Telles e Cabannes - for procedente, é possível dizer que existe uma associação entre a estrutura do mercado e a forma como os indivíduos ressignificam suas posições em relação ao trabalho, trazendo implicações para o tratamento da pobreza.

Mas essa forma de tratar a pobreza a partir de significados atribuídos e releituras de trajetórias em vista de um mercado de trabalho fluido e que se mostra incapaz de prover posições estáveis no cotidiano (e os referidos estudos são exemplares na apreensão dessas dinâmicas), acaba por deixar em aberto outras transformações que se passam no seio do mercado de trabalho, e é justamete aí que acreditamos poder avançar, a saber: buscando traçar relações entre o sistema de proteção social e a estrutura ocupacional.

Do que foi apontado até aqui em relação ao processo de expansão do assalariamento, sua vinculação ao sistema de proteção social, e as transformações no mercado de trabalho nas décadas recentes, nos nutriremos para balancear a literatura de que trataremos no capitulo seguinte e o estudo empírico que lhe segue. Já o paralelo que buscamos traçar acima e as suas implicações para a pobreza e suas novas configurações, serão uma refinada fonte de calibragem do que nos dirão os dados e os resultados que espelham.

\subsection{Considerações conclusivas e pontos em aberto para uma proposta de investigação}

Finalizando este capítulo, gostaria de retomar, reorganizando, alguns pontos tratados até aqui, mesmo com o risco de ser repetitivo, mas com a vantagem de sintonizar o leitor com o fio da construção do argumento desta dissertação, essencial a entendermos o esforço de análise empírica que nela se contem.

Se quisermos seguir uma espécie de cronologia, podemos dizer que, em primeiro lugar, o processo de expansão da mercantilização da oferta potencial de trabalho e do 
assalariamento formal são características estruturais conformadoras do mercado de trabalho no Brasil, bem como das perspectivas relativas ao modo como a pobreza a ele se articulou. Primeiramente, nos diagnósticos relativos à "marginalidade" e "informalidade" que, conquanto não possam ser traduzidos como perspectivas sobre pobreza, traziam para o centro do debate os desafios de incorporação de um amplo contingente de trabalhadores à dinâmica capitalista moderna. Não sem razão os chamados "pobres urbanos" estiveram no centro do seu interesse.

Simultaneamente, tais aspectos se forjaram alicerçados sobre um sistema de proteção social e da cidadania que a este se articulava. Mesmo com a mudança de significado que perpassou a temática e as propostas para o enfrentamento da pobreza a partir de 1980, tendo a renda per capita ancorada no salário mínimo como parâmetro e, portanto, desvinculando-se (ao menos de certa forma) da privação de direitos do ponto de vista da sua concepção, é justamente em virtude da expansão do assalariamento nas décadas precedentes que estas são fundadas.

Entretanto, quando finalmente o Brasil acabara de montar o seu mais universalista marco legal da cidadania e de proteção social com a Constituição de 1988, teve lugar uma série de transformações na estrutura econômica mundial e nacional, impactando profundamente a estrutura do mercado de trabalho e a configuração da pobreza. Novas institucionalidades passaram a conformar o padrão de inserção e de percursos; elas resultaram na perda de horizontes estáveis, seja no interior do próprio mercado, seja nas praticas cotidianas de acesso aos meios de sobrevivência. Não por acaso, os prognósticos em meados e fins da década de 1990 colocavam em primeiro plano a perda da centralidade do trabalho como modelador da coesão social e das trajetórias individuais que, se bem diferentes do que havia ocorrido com a crise da sociedade salarial na parte de cima do equador, comportavam a condição de instabilidade permanente como modeladora do fenômeno. Por outro lado, e significativamente, essas duas décadas foram igualmente marcadas por uma crescente expansão da proteção social na base da pirâmide e, mais especificamente, dos programas de combate à pobreza.

Se da ótica do mercado de trabalho e também dos percursos ocupacionais tais instabilidades se acentuaram, os anos mais recentes se caracterizam pela inclusão 
maciça de um elevado contingente de trabalhadores ao setor protegido desse mercado. Cabe destacar que, embora não se trate de proteção ao trabalho, em seu conteúdo, como a propiciada pela CLT, tendo em vista a cesta agora mais exígua de benefícios que a acompanha, a inclusão via mercado - associada principalmente às políticas de acesso ao credito, de valorização real do salário mínimo e de transferência de renda que tiveram lugar recentemente - contribuiu decisivamente para a redução da pobreza e, consequentemente, para sua articulação com o mercado de trabalho. Desta forma, o que nos países de Welfare State avançado é em geral percebido como uma fragilização de direitos historicamente conquistados que forneceram os parâmetros de integração social (Kowarick, 2003), aqui é tido como mecanismo institucional de redução da pobreza e da desigualdade (Singer, 2012; Baltar et al, 2010, dentre outros).

Até aqui buscamos apresentar alguns aspectos que acreditamos centrais para bem compreendermos as mudanças recentes no tratamento da pobreza, do mercado de trabalho e da proteção social. Entretanto, há alguns pontos em aberto que merecem ser investigados. No que tange à relação entre pobreza e proteção, o problema é sempre colocado em termos da insuficiência da proteção social em incorporar uma ampla parcela da população, garantindo-lhe mecanismos não mercantis de acesso à renda e ao bem estar. Ou seja, a relação entre pobreza e proteção se configura, antes de tudo, como uma questão de ampliação da cidadania e dos serviços de assistência que podem e devem ser prestados pelas instituições do Estado.

Quando nos centramos a observar o modo como se entende a relação entre mercado de trabalho e pobreza, as perspectivas, na maioria das vezes, tomam o mercado de trabalho como um dado, externo ao problema em análise, para, a partir daí, compreender as mudanças nos significados atribuídos às trajetórias ou, o que é ainda menos satisfatório, para descrever posições sociais produzidas por mecanismos estruturais.

Esta nos parece uma fragilidade argumentativa e é justamente em relação a esse ponto que pretendemos avançar. Pretendemos explorar o modo como a dinâmica da estrutura ocupacional se articula com os fenômenos até aqui descritos, ou seja, como ela responde aos constrangimentos estruturais colocados pelos sistemas de proteção, e em que medida a análise das suas transformações contribui para o entendimento da dinâmica e da natureza da pobreza. 
Chegados a este ponto, podemos agora formular as duas principais perguntas gerais que nos movem:

- Como compreender a evolução da pobreza a partir do comportamento da estrutura ocupacional?

- Como o comportamento da estrutura ocupacional responde aos constrangimentos colocados pelos sistemas de proteção social?

Foi justamente para subsidiar a análise da estrutura ocupacional e da sua relação com o regime de proteção e à pobreza que conferimos tamanha importância à expansão do assalariamento e de como este se articulou historicamente à escassa capilaridade da proteção social no Brasil. E, se bem seja certo que essa articulação informou boa parte das perspectivas sobre pobreza, trabalho e proteção social, nenhuma atenção foi dada à estrutura ocupacional enquanto elemento central ao entendimento da dinâmica interna do mercado de trabalho, e que responde aos constrangimentos dos sistemas de proteção. Para ser mais claro: as transformações da estrutura ocupacional não foram, até aqui, levadas em conta na análise do comportamento da pobreza e acreditamos que, ao fazêlo, ganharemos em poder explicativo.

Nessa via, o capitulo seguinte estará dedicado a apresentar a literatura que se debruçou sobre a forma como se articulam estrutura ocupacional, proteção social e desigualdades. Ao fazê-lo, nos demos conta de outra lacuna, igualmente presente nesse filão de literatura que passamos a explorar: nela, a pobreza, na maioria das vezes, é tida como um mero resíduo desses processos, e não como fenômeno relevante a ser trabalhado. Apesar disso, acreditamos que, se bem tratadas, as perspectivas teóricas que apresentaremos a seguir, em complementaridade com o até então exposto, possibilitarão uma profícua articulação para o estudo da relação entre pobreza, proteção social e mercado de trabalho. 


\section{REGIMES DE PROTEÇÃO SOCIAL, ESTRUTURA OCUPACIONAL E DESIGUALDADES}

\subsection{Introdução}

No capítulo precedente, arguimos que os estudos sobre mercado de trabalho e pobreza deixaram até aqui em aberto um novo e promissor caminho analítico, a saber, a possibilidade de abordar o tema sob um novo prisma, o da relação entre sistemas de proteção e estrutura ocupacional.

Neste capítulo pretendemos avançar nessa direção. Privilegiar analiticamente o estudo das ocupações significa adotá-las como unidade de análise estruturante das posições sociais. Desta forma, longe de assumirmos que a oferta de trabalho é constituída por indivíduos desenraizados de estruturas sociais e que atuam, por isso mesmo, de forma atomizada no mercado, abraçaremos uma perspectiva que, além de considerar aspectos relativos à demanda por trabalho, leva em conta especificidades relativas à institucionalização desse mercado numa estrutura ocupacional e em hierarquias de status.

Entretanto, não podemos perder de vista que tal estrutura, sua evolução, e as implicações que acarreta para o fenômeno da pobreza são, elas também, contingentes do arcabouço institucional vigente, fornecido pelos sistemas de proteção social. Portanto, ao adotarmos as ocupações como componente estruturador do ordenamento social, consideraremos tanto os aspectos relativos à hierarquização das posições, quanto os de diferenciação social entre as ocupações e os indivíduos, de maneira a ultrapassar enfoques meramente centrados na renda e/ou no nível educacional dos indivíduos.

Nesse sentido, fica evidente o alvo deste capítulo e, sobretudo, que não pretendemos fazer da estrutura ocupacional um objeto de interesse em si mesmo. Se mais não fosse, porque de há muito se consolidou, na sociologia, um fértil e robusto campo de estudos no tratamento das desigualdades, da estratificação e da mobilidade, que não cabe aqui reconstituir. Ao contrário, tiraremos partido desses avanços assumindo, de início, que a estrutura ocupacional se constitui num sistema ordenado de hierarquias de posições sociais que pode, por isso mesmo, ser tomado como uma proxy da estrutura de status. 
O capítulo está assim organizado. Na primeira seção, trataremos dos regimes de proteção social enquanto sistemas de estratificação e das suas implicações para a desmercantilização das condições de sobrevivência individual, buscando traçar paralelos com o caso brasileiro. Nas duas seções seguintes discutimos perspectivas teóricas que trataram da evolução da estrutura ocupacional nos países desenvolvidos tendo em vista o impacto das transformações tecnológicas, as alterações na composição da oferta e de como os regimes de proteção medeiam esses processos. Posteriormente, identificamos como este debate repercutiu quando do tratamento das grandes metrópoles enquanto unidades de analise. Encerraremos o capítulo tecendo algumas considerações para a condução do estudo empírico.

\subsection{Regimes de proteção social e desmercantilização}

O debate sobre a emergência e desenvolvimento do Welfare State nos países de economia avançada apresenta uma pluralidade de perspectivas, já bastante discutidas por vários autores (Esping-Andersen, 1990; Offe, 1989; O’Connor, 1977; Marshall, 1965; Wilensky, 1975; Titmuss, 1959). Independentemente das variações interpretativas, é hoje consensual que o Welfare State é uma forma de organização e atuação do Estado que se encontra historicamente vinculada ao processo de industrialização e à organização fordista da produção, onde os direitos, tal como previstos naquele tipo de ordem social, envolviam o acesso a serviços de proteção social. O rápido crescimento dessas economias no pós-guerra, a expansão do assalariamento e o estabelecimento da cidadania como princípio para a concessão de direitos constituíram as bases da legitimação e atuação dessa forma de organização do Estado nos países centrais. A despeito das diferenças entre os regimes, suas dinâmicas econômicas internas estiveram escassamente constrangidas pelo cenário econômico internacional, numa situação que foi designada como "embedded liberalism" (Ruggie, 1982; Fritz e Sharpf, 2000).

Em revisão bibliográfica sobre o tema, Arretche (1995) distingue duas correntes principais segundo o peso atribuído às variáveis analíticas na interpretação acerca da emergência e desenvolvimento do Welfare State nos países centrais: uma de cunho mais 
economicista, que toma o processo de industrialização como pano de fundo explicativo; e outra de ordem político-institucional, que associa fatores relacionados "à luta de classes, a distintas estruturas de poder político, ou ainda a distintas estruturas estatais e institucionais" (Arretche, 1995 p. 5) ${ }^{24}$.

Duas abordagens nos permitem associar os modelos de proteção social ao tema das relações entre mercado de trabalho e pobreza. A primeira delas é a conhecida e influente visão de Esping-Andersen sobre os diferentes regimes de bem estar e suas origens. Para este autor, a configuração dos regimes de proteção social são o produto histórico de lutas de classes e o grau de desmercantilização do trabalho expressa o quão vitoriosas teriam sido as coalizões de esquerda em face ao "despotismo de mercado". O Welfare State é, parafraseando-o, "policy against market" (Esping-Andersen, 1990), e pode ser visto como um sistema de estratificação pois condiciona o acesso a recursos distintos e altera, em maior ou menor grau, as condições de alocação dos indivíduos e famílias no interior da estrutura social.

A evolução do Welfare State reflete as respostas institucionais às pressões por "desmercantilização". Este conceito, central ao seu argumento, diz respeito ao grau em que indivíduos e famílias podem garantir um nível de vida socialmente aceito independentemente da participação no mercado. A demercantilização, nesse sentido, expressa liberdade em face ao mercado (Esping-Andersen, 1990, p. 37). São a força, o escopo e a qualidade dos direitos sociais que determinarão o grau de desmercantilização, que pode se expressar em diferentes intensidades nas diversas dimensões da vida social e na provisão dos serviços. E é justamente na medida em que o Estado provê serviços independentemente da participação no mercado que ele passa a se configurar enquanto instituição central à configuração do sistema de estratificação e de ordenamento das classes. Se concordamos com Weber (1982) que o "poder" é a dimensão irredutível da estratificação e que, na sociedade moderna, o mercado emerge enquanto instituição central - embora não a única - na distribuição das oportunidades e no ordenamento dos indivíduos no interior da estrutura social, qualquer outra instituição (no caso, o Welfare State) que venha "retirar" do plano do mercado, a partir de lutas

\footnotetext{
${ }^{24}$ Para o presente estudo não nos interessa revisitá-las, visto que não estamos tratando dos "condicionantes estruturais" da emergência do Welfare State. Antes disso, trataremos de duas abordagens que permitirão, no decorrer do presente trabalho, associar os diferentes modelos de regimes de proteção social ao mercado de trabalho e à pobreza.
} 
travadas no seu interior, algum bem ou serviço que nele se obteria, acaba inevitavelmente por alterar a dinâmica do ordenamento da configuração social e das relações de poder.

Os serviços de proteção influenciam a dinâmica da estratificação principalmente sob a ótica da regulação do trabalho. No clássico trabalho de 1990, três dimensões principais são analisadas por Esping-Andersen: i) as condições em que as pessoas deixam o mercado de trabalho e se tornam beneficiárias dos serviços de bem-estar (com ênfase para a aposentadoria); ii) o grau de autonomia em que os trabalhadores podem requerer licença remunerada; e iii) as condições em que as pessoas ingressam em postos de trabalho. (Esping-Andersen, 1990 p.144). Estes parâmetros indicam o grau de desmercantilização e a liberdade frente ao mercado de trabalho. O grau em que o Estado influencia a oferta de trabalho e disponibiliza/regula serviços de proteção condiciona, assim, e muito fortemente, a decisão individual sobre inserir-se no mercado de trabalho, ou mesmo mudar e/ou deixar o emprego. Longe de se tratar de um cenário de livre competição de oferta (trabalhadores) e demanda (empregadores), o que se observa são decisões que dependem em larga medida da configuração institucional que o mercado assume. Do ponto de vista da firma, a lógica é semelhante. A despeito de variações substanciais entre os países, os diferentes pactos estabelecidos no pós-guerra entre capital e trabalho, com vistas a garantir o pleno emprego, estabeleceram balizas institucionais que influenciaram de forma decisiva a maneira pela qual a relação entre ambos se consolidou.

Sendo assim, elabora uma tipologia acerca dos diferentes regimes de bem estar que espelha a maneira pela qual os diferentes países apresentaram respostas institucionais às questões apresentadas acima: i) o modelo "liberal" (Estados Unidos, Grã-Bretanha, Austrália, Canadá e Suiça); ii) o "conservador" (Alemanha, Áustria, França, Japão, Bélgica e Itália); e iii) o "social democrata" (países escandinavos). As respostas, por sua vez, são os resultados das lutas de classes travadas entre capital e trabalho, no que a força dos partidos de esquerda e sua longevidade no poder são aspectos centrais para se compreender as diferentes trajetórias institucionais.

A perspectiva original de Esping-Andersen é, sem dúvidas, extremamente profícua para se compreender as variações nas relações que se estabelecem entre estado e sociedade 
em diversos contextos. Entretanto, outros autores, apoiados na vertente conhecida como "variedades de capitalismo", têm dirigido uma critica ao sentido que o primeiro confere à noção de "desmercantilização". Essa corrente tem influenciado estudos sobre temas os mais diversos e, novamente, estaremos atentos apenas àqueles que têm se dedicado a compreender os diferentes regimes de proteção social a partir do seu quadro teórico mais geral (Mares, 2003; Swenson, 2002; Iversen, 2005; Estevez-Abe, 2008).

O principal argumento desses autores é que a proteção social não pode ser vista apenas em termos da dicotomia "mercantilização x desmercantilização" ou "Mercado x Estado". Os “welfare production regimes", como os autores preferem chamar, são parte de um amplo complexo institucional que constitui os regimes de produção. Complementaridades institucionais ${ }^{25}$ que se reforçam mutuamente junto a formas particulares de inserção na economia internacional, os regimes de produção podem ser caracterizados segundo os níveis de coordenação da atividade econômica, das relações industriais, dos sistemas educacionais e de treinamento e de governança corporativa.

Partindo desse arcabouço analítico, esses autores atrelam os incentivos institucionais produzidos pelos sistemas educacionais e de treinamento aos regimes de proteção, alterando de forma significativa o sentido dado à noção de "desmercantilização". O argumento é relativamente simples. Naqueles países onde os sistemas educacionais são mais diretamente vocacionais e vinculados ao sistema produtivo (firm-specific skills e industry-specific skills), como na Alemanha e nos países nórdicos, os sistemas de proteção social tendem a ser mais generosos. Esta constatação assume que, ao vincular o trabalhador a um sistema de treinamento tensionadamente especifico - e consequentemente voltado a uma inserção específica no mercado de trabalho - a proteção no trabalho e ao desemprego deve ser suficientemente atrativa; isto porque, dada a especificidade da formação do trabalhador, lhe será mais difícil engajar-se em outro tipo de atividade. Sendo assim, há um forte interesse dos empregadores na constituição de um sistema de proteção social generoso e atrelado às atividades econômicas, de modo a tornar os indivíduos mais dependentes de um determinado tipo de trabalho.

\footnotetext{
25 "Two institutions can said to be complementarily if the presence (or efficiency) of one increases returns (or efficiency of) the other" (Hall e Soskice, 2001, p. 17).
} 
Por outro lado, naqueles países onde o sistema educacional é generalista no tipo de formação que confere, como nos Estados Unidos, a lógica é inversa. O trabalhador tem, pela formação recebida, a chance de maior transito entre diferentes setores do mercado de trabalho; nesse caso, a ausência de incentivos colocados pelo sistema de proteção social se associa a uma menor dependência a setores específicos do sistema econômico.

É importante ressaltar que reconhecer esse menor nível de dependência não equivale a fazer qualquer espécie de avaliação normativa dos modelos. A ênfase está, sobretudo, em quão vinculado o trabalhador se encontra ao modo de atuação das firmas. A desmercantilização, nesse caso, é vista sob uma ótica distinta, significando antes de tudo dependência em relação ao tipo de trabalho que o individuo exerce. Se este lhe propicia maior segurança, por um lado, torna-o menos independente para transitar pelo mercado de trabalho, por outro.

As implicações desta perspectiva para a análise da (re) produção das desigualdades e da pobreza são diversas. De fato, como bem nota Iversen (2005), há uma forte associação empírica entre os níveis de desigualdade, o tipo de sistema educacional/treinamento, e o escopo da proteção social. Em virtude dos menores níveis de heterogeneidade de qualificação da força de trabalho, por um lado, e da regulação institucional sobre o mercado de trabalho, por outro, a desigualdade salarial tende a ser consideravelmente menor nos países com sistemas educacionais mais vinculados à atividade econômica - a Alemanha é o protótipo desse caso. O lado oposto constitui um sistema assentado numa formação generalista e num mercado mais flexível - novamente tendo os Estados Unidos como caso exemplar - em que a determinação dos salários está mais sujeita à lógica de mercado.

Na mesma linha argumentativa, este ultimo modelo tende a limitar as oportunidades dos menos qualificados e a criar desincentivos à qualificação, sendo mais propenso a produzir círculos viciosos de pobreza (poverty traps) que são intensificados pela baixa capilaridade da proteção social. Por outro lado, tendem a ser menos segregados sexualmente, justamente porque as possibilidades de transito no mercado são maiores. No primeiro caso, a forte dependência criada pela interação entre o sistema de treinamento e a proteção social tende a deslocar as mulheres para nichos específicos e inferiores do mercado de trabalho. 
Como se pode observar, portanto, há uma divergência entre os autores no que concerne tanto ao significado da desmercantilização quanto ao grau em que sua efetividade se articula com o padrão institucional do mercado de trabalho. Ao enfatizarem a forma como sistema educacional e de treinamento estão intimamente articulados ao padrão de proteção social e à formatação do mercado de trabalho, a lógica de encontro entre oferta e demanda se altera em virtude dos vetores institucionais que medeiam não apenas seu encontro, mas a própria formação da oferta. Se bem seja certo que esta noção mais geral também se encontra presente em Esping-Andersen, ao conferir demasiada centralidade aos sistemas de bem estar enquanto formatadores últimos do mercado de trabalho, este autor acaba por minimizar o papel desses sistemas na produção qualitativa da oferta, e não apenas quantitativa.

Sem querer forçar uma prematura transposição teórica para o caso brasileiro, mas tentando traçar um breve paralelo, sabemos que aqui o sistema educacional se aproxima mais de um modelo generalista - embora fortemente segmentado entre os setores público e privado, o que constitui outro vetor institucional produtor de desigualdades. $\mathrm{O}$ sistema escolar, a despeito de um marginal sistema de ensino técnico (Schwartzman e Brock, 2005), é destituído de qualquer orientação em relação às atividades produtivas, bem como é consideravelmente baixo o investimento do setor privado em qualificação de mão de obra. Schneider (2009) mostra que este baixo investimento está intimamente relacionado à intensa rotatividade no mercado de trabalho, como num circulo vicioso entre os dois fatores.

Além disso, a universalização da educação básica no Brasil só veio a se consolidar nas décadas recentes. Em 1991, a taxa de escolarização líquida do ensino fundamental era de menos de 80,0\%, para em 2000 e 2010 atingirem cifras próximas dos 100,0\%. Por outro lado, o Ensino Médio ainda constitui uma importante barreira educacional. Em 1991, pouco mais de 15,0\% dos jovens entre 15 e 17 anos frequentava o segundo grau e, embora estas cifras tenham subido de maneira significativa nas décadas de 1990 e 2000, esses percentuais ainda são de apenas 60,0\% e 70,0\%, respectivamente. No Ensino Superior, também observamos uma tendência de forte crescimento a partir dos anos 1990, mas ainda comportando baixos resultados em relação ao grupo etário de 18 a 24 anos: 7,0\%, 34,1\% e 60,7\%, respectivamente em 1991, 2000 e 2010. 
Como inúmeros estudos já trataram de demonstrar (Ribeiro, 2007; Hasenbalg e Silva, 2003; Fernandes, 2009, dentre outros), o acesso desigual ao sistema de ensino é um fator determinante para reprodução das desigualdades no Brasil (como em todos os países, embora com implicações distintas), da mesma forma que os menos escolarizados estão sempre mais propensos a se encontrarem em situação de pobreza. Para não nos esquecermos, ainda, de que a noção de transição entre escola e trabalho esteve longe de assumir aqui a relativa harmonia cronológica observada nos países onde a universalização do sistema educacional ocorreu mais cedo (Hasenbalg e Silva, 2003; Guimarães, 2004; Comin e Barbosa, 2011).

O que buscamos ressaltar é que, mesmo com as especificidades da trajetória brasileira, é possível afirmar que existe uma certa semelhança institucional entre o modelo brasileiro e aquele onde há pouca integração entre os sistemas de educação/qualificação e as atividades produtivas ${ }^{26}$, na medida em que há pouca diferenciação do sistema em termos de conteúdo/formação e a maioria dos egressos é lançada ao mercado de trabalho sem o suporte de um efetivo sistema de intermediação entre os trabalhadores e as firmas. Neste caso, há uma sorte de complementaridades institucionais negativas entre a intensa rotatividade no mercado de trabalho, o baixo nível de qualificação da mão de obra e o desincentivo das firmas em investirem em qualificação profissional, resultando em um

\begin{abstract}
low-skill trap or equilibrium. The basic coordination problem is that workers don't invest individually in acquiring skills because firms do not offer high skill, high wage jobs. Firms in turn have incentives to invest in production processes that don't require skilled labour, because skilled workers are scarce. (Schneider, 2009, p. 568).
\end{abstract}

Embora o ponto aqui passe longe da temática da pobreza e se articule em torno de aspectos relativos a como as instituições colocam (des)incentivos à competitividade e ao desenvolvimento econômico, algumas de suas pistas apresentam potencialidades no tratamento das nossas questões.

Em primeiro lugar, mais uma vez a rotatividade aparece como um aspecto distintivo do mercado. No primeiro capitulo, buscamos mostrar a existência de um paralelo entre esta característica estrutural e sua reconfiguração nas duas últimas décadas e a forma como a pobreza foi tematizada a partir das rupturas das trajetórias e do estabelecimento de

\footnotetext{
${ }^{26}$ Nota-se que aqui estamos dizendo de uma semelhança em relação ao modo pelo qual o sistema educacional se articula ao mercado de trabalho, e não da totalidade das instituições que perpassam o mercado de trabalho e a proteção social.
} 
horizontes estáveis em relação às posições no mercado. Cremos, entretanto, ser possível trazê-la para a análise sob uma ótica distinta, qual seja: a de como o mercado de trabalho se mostra mais ou menos propenso a incorporar um certo perfil de trabalhadores, tendo em vista o nível de qualificação da mão de obra disponível. Mais do que isso, esta "propensão", como estamos chamando, guarda uma profunda relação com as institucionalidades colocadas pela regulação das relações de trabalho.

No tocante à noção de "desmercantilizaçao" do trabalho, preferimos deixar este ponto em aberto por enquanto. Afinal, se é certo que no Brasil ainda se encontre fortemente associada ao setor formal de trabalho (o exemplo mais forte é de que o seguro desemprego não é concedido aos que se desligam do setor informal), a expansão do assalariamento formal nas últimas décadas incorporou um elevado contingente de trabalhadores, permitindo-lhes o acesso a uma série de benefícios, mesmo sendo os mesmos apenas parte do que prevê a CLT para os trabalhadores contratados por tempo indeterminado. Retomando parte do argumento do Capitulo 1, a flexibilização dos direitos trabalhistas em meados da década de 1990 significou uma guinada no sentido de mercantilizar as relações de trabalho, o que, no argumento de Esping-Andersen, representaria uma maior sujeição dos trabalhadores aos mecanismos puramente mercantis.

Esta sujeição, entretanto, é reforçada pela baixa diferenciação da composição qualitativa do nível educacional da oferta de trabalho, por um lado, e da composição da demanda, por outro. Na medida em que há um elevado contingente de trabalhadores relativamente mal qualificados e sendo as regras de contratação e admissão mais frouxas (como nos empregos temporários e terceirizados), constrói-se um ambiente institucional propicio para uma intensa rotatividade da mão de obra, de modo que, ao longo dos anos 1990, os menos qualificados ficaram mais expostos às transformações na estrutura produtiva e à reestruturação micro-organizacional (Cardoso, 2013). Nos 2000, como mostraremos no capitulo seguinte, mesmo com a intensa rotatividade, o mercado de trabalho na RMSP se mostrou consideravelmente mais receptivo aos menos qualificados, e o padrão de geração de empregos que se efetivou contribuiu para a redução da pobreza no período.

Se ampliarmos o escopo de analise para a esfera da proteção social que ultrapassa as relações de trabalho, observamos que há vetores com diferentes sentidos que perpassam 
esse processo. Estamos nos referindo, especialmente, ao modo como a expansão da proteção social não contributiva nos últimos 20 anos tem proporcionado o acesso ao bem estar por vias externas ao mercado de trabalho. Sobre esse aspecto, a política de valorização do salário mínimo nos últimos 10 anos contribuiu decisivamente para o aumento da renda não apenas para os que estão no mercado (seja no setor formal ou informal), mas também porque uma série de benefícios tem no salário mínimo legal o seu parâmetro ${ }^{27}$.

Como a literatura internacional, voltada a entender a dinâmica do mercado de trabalho nos países capitalistas avançados, se debruçou sobre as interações entre oferta, demanda e estrutura institucional do mercado de trabalho? Enfrentar essa questão pode ser um bom modo de fundamentar a abordagem que estamos propondo e dar sentido aos achados que produzimos, com vistas a bem observar como o padrão de evolução da estrutura ocupacional se associa ao sistema de proteção e à pobreza.

\subsection{Mercado de trabalho e estrutura ocupacional na transição dos regimes de proteção}

Ao longo dos anos 1970, o desemprego cresceu consideravelmente tanto nos Estados Unidos como na maioria dos países do oeste europeu. Entretanto, nos anos 1980 e 1990, enquanto na America observava-se uma reversão desse quadro, convivendo com elevação dos níveis de desigualdade, na Europa o cenário se manteve sem muitas variações (DiPrete and al, 2005; Freeman e Katz, 1995).

Esta realidade proporcionou a emergência do que alguns autores (DiPrette et al, ibid; Oesch e Menés, 2010; Fernandez-Macíaz, 2012) denominaram de "teoria unificada" (unified theory). Ela propugnava que as diferenças entre as estruturas dos mercados de trabalho norte-americano e europeu teriam produzido reações distintas ao ambiente macroeconômico desde os anos 1970/80. De acordo com esta teoria, os Estados Unidos

\footnotetext{
${ }^{27}$ Destacam-se, nesse caso: i) o valor da aposentadoria; ii) o critério para cadastramento no Cadastro Único, que serve como instrumento de gestão das políticas sociais (em especial o Programa Bolsa Família); iii) o Beneficio de Prestação Continuada (BPC), que concede uma transferência mensal de 1 salário mínimo a idosos de mais de 64 anos ou mais sem aposentadoria, ou a deficientes de qualquer idade sem condições de trabalhar.
} 
seriam mais propensos a tolerar maiores níveis de desigualdade enquanto que os estados europeus tenderiam a priorizar retornos mais equânimes no interior do mercado de trabalho. A interação entre os choques macroeconômicos e tais distinções entre países explicariam as trajetórias variantes, de modo que, num contexto de constante queda na demanda por trabalhadores menos qualificados, os países se encontrariam em uma espécie de trade-off entre o crescimento de empregos mal remunerados na base ou a manutenção de altas taxas de desemprego dentre os menos qualificados.

O argumento parte de três proposições básicas: i) as principais características institucionais da maior parte dos países industrializados mantiveram-se relativamente estáveis desde a década de 1970; ii) Durante este período, os países experimentaram choques macroeconômicos comuns, como as quedas nas taxas de produtividade, aumento do fluxo comercial internacional, e mudanças tecnológicas que teriam diminuído a demanda relativa por trabalhadores menos qualificados; e iii) o resultado do comportamento do mercado de trabalho domestico consistiria na interação entre suas características institucionais e o ambiente macroeconômico global.

Nos Estados Unidos, donde a configuração institucional é marcada pela fragilização dos sindicatos, mecanismos de ajuste salarial descentralizados e por maior nível de flexibilidade das relações de trabalho, a estrutura ocupacional teria se adaptado às transições macroeconômicas de modo a criar uma vasta gama de empregos precários e mal remunerados, minimizando o problema do desemprego mas intensificando a dispersão e a desigualdade salarial. Na Europa, por outro lado, a rigidez das instituições de regulação do mercado de trabalho - com o forte controle sobre a alocação do trabalho, os altos custos de demissão e a capilaridade da proteção social - teria causado o impacto inverso: a estrutura salarial e a desigualdade pouco se alteraram, mas os níveis de desemprego impulsionados pela queda na demanda por trabalhadores menos qualificados os teriam tornado "redundantes economicamente".

Uma ampla linha de debate se desenvolveu em torno dos motivos pelos quais a demanda teria penalizado os menos qualificados. Especialmente na literatura econômica, mas também em parte da sociológica, privilegiou-se observar como e em que intensidade alterações na composição da oferta (nível de qualificação, imigração, 
ingresso das mulheres no mercado de trabalho) e na demanda (incrementos tecnológicos na produção e tipo de empregos criados) teriam impactado esses processos ${ }^{28}$.

O foco na demanda no período da transição do Welfare State reflete a mudança estrutural do declínio do modelo fordista e a forma como a nova estrutura produtiva impactou negativamente os trabalhadores menos qualificados e as ocupações intermediárias e/ou mal remuneradas. A lógica desta linha argumentativa é de que a evolução tecnológica teria "enviesado a demanda" por trabalhadores mais qualificados (skill-biased), de um lado, ao mesmo tempo teria sobrado uma fatia menor do mercado de trabalho para acomodar o grande contingente de trabalhadores menos qualificados, que passaram a ser absorvidos em ocupações precárias e mal remuneradas. Trata-se, nessa linha de interpretação, do que poderia ser considerado um clássico exemplo de exercício da relação entre oferta e demanda: no topo, a oferta cresce menos do que a demanda, jogando o preço dos salários para cima. Na base, ao contrário, a oferta cresce mais do que a demanda, reduzindo o valor do preço do trabalho e aumentando o desemprego. O resultado, tal como diagnosticado principalmente para os Estados Unidos, não poderia ser outro que não o aumento da desigualdade salarial e o aumento relativo dos working poor na base da pirâmide.

I conclude that skill-biased technical change is likely to have accelerated over the past several decades. This conclusion is based on the sharp increase in overall inequality starting in the 1970 s and on the fact that returns to schooling rose over the past thirty years despite the unusually rapid increase in the supply of educated workers (Acemoglu, 2002).

Nesta perspectiva - da assim chamada "hipótese SBTC (skill-biased technological change)" - o fator crucial para o aumento da desigualdade seriam as transformações na demanda, induzidas pelos níveis de tecnologia empregados. A previsão era de um aumento continuo na demanda por trabalhadores mais qualificados em oposição aos menos qualificados. Entretanto, ao invés de um crescimento uniforme da demanda por maior qualificação, o que veio a ser diagnosticado foi um processo de polarização da

\footnotetext{
${ }^{28} \mathrm{Na}$ literatura econômica, uma outra linha se debruçou sobre como as mudanças nas regras do comercio internacional e a globalização teriam impactado o mercado de trabalho dos países desenvolvidos. O argumento subjacente é de que o emprego menos qualificado teria migrado para os países do "terceiro mundo", onde é maior a oferta e menor o custo do trabalho. Mas, por se tratar de um tema que foge largamente às pretensões do nosso estudo, não o contemplaremos aqui.
} 
estrutura ocupacional $^{29}$ e um aumento relativo também dos estratos ocupacionais de mais baixa qualificação ${ }^{30}$ - em especial nos Estados Unidos e na Inglaterra.

Uma explicação mais refinada viria com o artigo seminal de Autor, Levy e Murnane (2003), que se constitui numa versão nuançada da hipótese SBTC, porque ancorada também na centralidade das mudanças tecnológicas sobre a demanda por trabalho. Num cruzamento bidimensional entre nível de rotinização das tarefas e exigência cognitiva (manuais e não manuais), os autores distinguem quatro grandes grupos de ocupações: "cognitivos não rotineiros"; "cognitivos de rotina"; "não cognitivos de rotina"; e "não cognitivos não de rotina". O processo de mecanização das tarefas no interior das firmas - em especial aquelas realizadas por computadores - tenderia a substituir as ocupações de rotina (cognitivas ou não); e como estas se encontravam no meio da distribuição salarial, estaria aí a chave para se compreender a polarização. Crescem as ocupações "cognitivas não rotineiras" no topo (gerencia e controle, principalmente) e as "não cognitivas não de rotina" na base (tais como motoristas, auxiliares de saúde, trabalhadores de care, etc.).

Concebendo especial centralidade à difusão dos processos informatizados, os autores afirmam que, por um lado, os aparatos mecanizados fornecidos pelo desenvolvimento tecnológico substituem as tarefas de trabalhadores de rotina que fazem apenas as "ações programadas"; mas, por outro lado, esses aparatos complementam os trabalhadores na execução de tarefas não rotineiras, que demandam flexibilidade, criatividade, capacidade em resolver problemas e comunicação complexa. Ambos os mecanismos substituição e complementaridade - aumentaram a demanda relativa por trabalhadores

\footnotetext{
${ }^{29}$ É importante ressaltar que o aumento da desigualdade salarial e a polarização ocupacional, embora possam estar vinculados, são processos marcadamente distintos. A polarização, nesse campo de estudo, se refere à estrutura ocupacional e leva em consideração a qualidade do emprego, qualquer que seja a medida utilizada para mensurá-la. Já a desigualdade salarial trata da dispersão de rendimentos. Do ponto de vista lógico ou mesmo teórico, nada impede que um mercado de trabalho seja fortemente polarizado em termos de estrutura ocupacional, mas com baixos níveis de desigualdade salarial. E a recíproca não é menos verdadeira: um alto nível de desigualdade salarial pode, perfeitamente, estar associado a um cenário de pouca ou nenhuma polarização da estrutura ocupacional. Empiricamente, entretanto, o que se observa é que a polarização, na maior parte das vezes, está associada a maiores níveis de desigualdade e dispersão salarial.

${ }^{30}$ A hipótese SBTC não é de todo incompatível com o diagnóstico da polarização, que já havia sido diagnosticada desde meados dos anos 1980. A SBTC previa, no longo prazo, a diminuição gradativa dos empregos de menor qualificação (Goos e Maning, 2007).
} 
que possuem uma vantagem comparativa em tarefas não rotineiras, em especial os mais qualificados.

\begin{abstract}
"our conceptual framework observes that the first-order impact of computerization is to displace (substitute for) a set of 'middle skilled' routine cognitive and manual tasks, such as bookkeeping, clerical work and repetitive production tasks. If these routine tasks are more complementary to highskilled, abstract tasks (problem-solving, management and coordination) than to 'non-routine manual' tasks (such as those performed by truck drivers, waiters and security guards), the computerization of routine work can lead to a polarization of the structure of employment and earnings" (Autor, Katz e Kearney, 2006, p. 4).
\end{abstract}

A "hipótese ALM" (ou "routinization hypotesis"), como é chamada, foi reforçada por Goos et al (2007; 2009) em estudo realizado para o Reino Unido. Os autores identificaram padrão de polarização da estrutura ocupacional semelhante àquele observado para os Estados Unidos, ao que associam ao processo de enxugamento das ocupações de rotina em decorrência de incorporação tecnológica e do crescimento dos setores de serviços.

There is a large increase in the employment shares of managerial and professional workers, an increase in lovely jobs that is mostly within industries. Both craft workers and machine operatives have large negative within and between components, reflecting both the impact of technical change and the shift toward services. Routine clerical occupations have large negative employment effects within industries with a sizeable positive between component reflecting the shift to services. The increase in the employment share of low-paid personal and protective services and sales occupations has a large within and between component, reflecting the fact that technology has not managed to do these jobs and reflecting the shift toward services (Goos e Manning, 2007, p. 120).

Outros autores, contudo, trataram de argumentar que, se é certo que a demanda tem induzido a uma maior necessidade por qualificação, é também na composição da oferta (escolaridade e imigração, especialmente) que pode ser encontrada parte das explicações para as mudanças observadas na estrutura ocupacional e salarial. Para os Estados Unidos, Goldin e Katz (2008) argumentam que, até os anos 1970, a oferta de trabalhadores qualificados cresceu em ritmo mais acelerado do que a demanda, fazendo com que os retornos educacionais declinassem gradativamente desde o início do século XX e o crescimento vivenciado no pós $2^{\text {a }}$ guerra fosse compartilhado de maneira menos desigual entre os estratos. Já a partir da década seguinte, o processo se inverte, de modo que os retornos voltam a crescer, contribuindo para o incremento dos níveis de desigualdade e da queda real dos salários na base da distribuição. 
The major difference across the period was not changes in demand but in supply. Shifts in the rate of growth in the supply of educated labor played a critical role in altering inequality trends. [...] most of the variation in educational wage differentials can be well explained by a simple supply and demand framework. (Goldin e Katz, 2008, p. 293)

Sustentando razões distintas, mas também focados na oferta, Wright e Dwyer (2003) argumentam que o incremento da imigração hipano-americana teria sido o principal fator explicativo da polarização ocorrida no mercado de trabalho norte-americano. Os autores observam que a grande maioria dos empregos criados na base da estrutura ocupacional é predominantemente vinculada aos imigrantes, ao passo que os empregos do "topo" são tipicamente preenchidos por brancos nativos. Ou seja, a polarização observada, seguida do aumento da desigualdade, resultaria antes de tudo da disponibilidade de um amplo contingente de imigrantes mal qualificados (muitos deles em situação ilegal de imigração), criando incentivos para a multiplicação de uma vasta gama de empregos mal remunerados na base

This very large expansion of low-end service jobs in the 1990s clearly indicates that there was a demand on the part of employers for such jobs. But demand alone is not sufficient to explain actual job creation; there must also be a pool of people willing to fill these jobs. Here the pivotal issue is immigration. As already noted, immigrants account for nearly two-thirds of the job growth in the bottom quintile of employment (Wright e Dwyer, 2003, p. 316).

Não cabe aqui avaliar a robusteza dos argumentos e dos resultados apresentados, a fim de vaticinar sobre a correção de uma ou outra perspectiva. Antes disso, o que se ressalta é a importância das mudanças, tanto na estrutura produtiva como na composição da oferta, como fatores indispensáveis na análise da estrutura ocupacional; e, mais especificamente, dos espaços do mercado de trabalho que se reservam aos menos qualificados e aos potenciais "pobres", estejam eles ocupados ou não. Embora a "pobreza" não esteja no centro da atenção destes estudos, é claro que tais alterações na estrutura do mercado acabam por condicionar, e de maneira decisiva, os riscos de que muitas pessoas, em virtude dos rendimentos e da qualidade da sua ocupação, possam vir a se encontrar em situação de pobreza.

Mas é possível ir além e aprofundar a discussão observando como as características institucionais do mercado de trabalho e dos sistemas de proteção social interagem com esses processos. Afinal, os comportamentos de oferta e demanda se materializam no interior de instituições que moldam as diferentes possibilidades de relações sociais que 
operam no mercado de trabalho, ao mesmo tempo em que condicionam e cristalizam a própria esfera de atuação da política pública. Avançar nessa direção será o alvo da sessão subsequente, de modo a sustentarmos parte do argumento que se desenvolverá, no próximo capítulo, com respeito ao caso brasileiro.

\subsection{Configuração institucional e evolução da estrutura ocupacional}

Sem sombra de duvidas, as mudanças no sistema produtivo do capitalismo globalizado pós-década de 1970 alteraram o padrão de geração de empregos e a forma como o mercado de trabalho se vincula aos sistemas de proteção social. Ademais, o aumento maciço da participação das mulheres, o fluxo migratório oriundo dos países em desenvolvimento e os efeitos das mudanças na composição etária da população (em especial a geração do baby-boom pós $2^{\mathrm{a}}$ guerra que chegara à idade ativa) transformaram em larga medida a estrutura da oferta. Essas alterações na oferta e na demanda não poderiam passar despercebidas.

Entretanto, as respostas a essas mudanças não foram uniformes; e principalmente as variações entre países que haviam compartilhado processos semelhantes necessitavam ser mais bem exploradas. O estudo pioneiro organizado por Freeman e Katz (1995), que veio subsidiar a "teoria unificada" à qual fizemos referencia nas páginas anteriores, desenvolveu um elegante modelo que levava em consideração a interação tríplice entre oferta, demanda e instituições (SDI - Supply, demand and institutions) na explicação dos padrões de diferenciação salarial entre uma gama de países desenvolvidos.

Os autores argumentam que, na medida em que tais economias operam em "mundos semelhantes" em termos de composição tecnológica, as mudanças na demanda deveriam ter efeitos semelhantes sobre a estrutura salarial. Já as alterações na oferta viriam a ser mais impactantes, em virtude do fato de que, mesmo tendo sido semelhantes a evolução constante dos níveis educacionais, são distintos os padrões de expansão da educação e as políticas de qualificação profissional.

Para Freeman e Katz, entretanto, explicar a magnitude das diferenças encontradas requer ir além desses determinantes. Eles argúem que há que se tomar em conta o peso 
das instituições do mercado de trabalho e a relação biunívoca que estas estabelecem com o comportamento da oferta e da demanda. Ou seja, da mesma forma que a interação entre oferta e demanda é dependente das instituições, estas também respondem às mudanças que se passam nas duas primeiras. Este duplo jogo contingencial pode ser sintetizado nas duas longas passagens abaixo:

The more centralized a wage-setting system, and the stronger the role of institutions in wage determination, the smaller will be the effect of shifts in supply and demand on relative wages, and, as a consequence, the greater will be their effect on relative employment. In addition, education and training market institutions, which determine the level of workplace skills for the less educated and the degree to which more and less educated workers can be substituted for one another in production, will also mediate the effect of market forces on wages and employment (Lynch 1994). A more egalitarian distribution of skills should dampen the effects of market shifts on wages and employment. Finally, social insurance and income maintenance institutions also affect wage setting by influencing supply and demand behavior (Blank 1994). For instance, generous income maintenance or unemployment benefits programs that allow workers to remain jobless for a long period can reduce their willingness to take low wages to obtain work and thus reduce supplyside pressures that generate greater earnings differentials (Freeman e Katz, 1995, p. 6)

In part, forces outside the labor market, such as political developments, will change labor institutions, but these institutions also respond to shifts in supply and demand. The important institutional changes in the 1980's were the decline in trade union power, which was exceptional in the United States, and the decentralization of collective bargaining that characterized diverse European countries. Both these developments are likely to produce greater earnings differentials (ibid, ibidem).

Partindo desse quadro analítico, os autores afirmam que a especificidade do aumento da desigualdade de rendimentos nos Estados Unidos, em oposição ao contexto europeu, reflete o componente descentralizado das instituições do mercado de trabalho - em especial aquelas de ajuste salarial e a fragilidade dos sindicatos - de modo que os salários estão mais à deriva das assim chamadas "leis de mercado". Por outro lado, os países da Europa Ocidental estariam mais sujeitos às elevadas taxas de desemprego como consequência da robusteza das suas instituições do mercado de trabalho, mas com menores níveis de desigualdade.

Mouw e Kalleberg (2010) e Kalleberg (2012) também associam a polarização do mercado de trabalho norte-americano e o crescimento da desigualdade às interações entre oferta, demanda e padrão institucional. À luz de um cenário de financeirização do sistema econômico, de mudanças na composição de força de trabalho que se torna cada vez mais diversa e da ausência de fortes instituições do mercado de trabalho, eles 
identificam um incremento das desigualdades entre as ocupações e o peso relativo de um pequeno número de ocupações específicas que, por assim dizer, se descolam da estrutura ocupacional como um todo.

The absence of strong labor market institutions, along with a weak labor movement and a relative lack of government regulation and interference, gave employers relatively free rein to seek employment arrangements that enhanced their flexibility, which in turn encouraged the expansion of polarized and precarious jobs (Kalleberg, 2012, p. 439).

Semelhante resultado foi encontrado por Mimieux (2007). Analisando os anos 1990, o autor constatou o aumento da desigualdade salarial no topo e a queda da desigualdade na base da distribuição de rendimentos; e também conferiu às instituições do mercado de trabalho uma importante participação nesses processos.

An alternative explanation that was suggested to explain inequality growth in the 1980s is based on changes in labor market institutions. I argue in this paper that, unlike SBTC, the institutional change explanation can help explain why inequality changes became concentrated in the top end after 1990, and why inequality grew more in the United States and the United Kingdom than in other advanced countries (Mimieux, 2007, p. 30).

A relativa fraqueza das instituições do mercado de trabalho nos Estados Unidos e na Inglaterra não poderia estar desassociada do modelo liberal de Welfare State tal como colocado por Esping-Andersen. Caberia, assim, explorar em que medida os outros modelos teriam apresentado respostas distintas a partir da "crise do fordismo". Este mesmo autor $(1990 ; 1999)$ já havia reconhecido que diferentes trajetórias da estrutura do mercado de trabalho refletem o peso dos regimes de proteção social, tanto por seu papel de formatadores das transformações de oferta e demanda, como (e principalmente) por sua capacidade de se entrecruzar com estas ultimas e de produzir diferentes efeitos, seja nos níveis de desemprego, seja na evolução da estrutura ocupacional.

Germany stands as a best-case version of European jobless growth; Sweden is the epitome of the Nordic welfare state-led model of service expansion; and the United States is, par excellence, the leading example of unregulated, market-driven employment (Esping-Andersen, 1999, p. 108).

Explorando mais profundamente o padrão de geração de empregos e as transformações na estrutura ocupacional com metodologia semelhante à utilizada por Wright e Dwyer (2003) para os EUA e por Goos et al $(2009 ; 2011)$ para a Europa, Fernandez-Macíaz (2012) e Oesch e Menés (2010) avaliaram o comportamento de mercados de trabalho de 
15 países europeus nas duas últimas décadas. Os autores criticam em especial o foco na explicação baseada no desenvolvimento tecnológico como a principal alavanca para a polarização dos mercados norte-americano e britânico, tal como diagnosticado por Autor et al (2003 e 2006) e por Goos et al (2007 e 2009), e argumentam novamente em favor das diferenças institucionais entre os países.

\begin{abstract}
A narrow focus on technology as the (main) factor determining the structure of employment leads to a narrow technological explanation of why such structure changes over time, and because most advanced European nations are experiencing the same type of technological change, they should change in roughly similar (polarizing) ways. However, if we depart from a more encompassing model, including not only technology but also institutions, then the range of possible explanations is widened: as there is an obvious plurality of institutional frameworks across Europe, we should expect plurality rather than homogeneity in the patterns of occupational change. (Fernandez-Macías, 2012, p. 8)
\end{abstract}

Essa pluralidade a que se refere Fernandez-Macías acima, e como mostram os resultados, corresponde em larga medida aos diferentes modelos dos regimes de proteção social. Nos países da Europa Continental que experimentaram um processo de desregulamentação do mercado de trabalho (Holanda, França, Alemanha, Bélgica e Luxemburgo), a tendência foi de polarização; já nos países escandinavos, os resultados foram de um forte upgrade da estrutura ocupacional ${ }^{31}$. A explicação reside principalmente na força dos sindicatos e nas estruturas salariais, que tornam os empregos na base da distribuição relativamente mais custosos e incentivam a criação de ocupações em atividades de maior valor agregado. Entretanto, os autores advertem que, se bem seja verdade que as diferenças institucionais minimizam o peso das transformações tecnológicas, estas ainda jogam fortemente no processo de transformação do mercado de trabalho, na medida em que interagem com uma série de fatores (alterações na oferta, regimes de proteção, sistema produtivo) e contribuem para moldar a trajetória da estrutura ocupacional.

Analisando o caso francês - outro exemplo do "regime conservador" - DiPrete et al (2005) criticam o que consideram um extremo reducionismo da "teoria unificada" na atribuição de distinções entre os Estado Unidos e o conjunto dos países europeus continentais no que concerne à flexibilização das relações trabalhistas e ao trade-off

\footnotetext{
31 Os autores ainda identificam, para os países da Europa do Sul (Itália, Grécia e Portugal) um crescimento das ocupações que se situam no meio da distribuição, reforçando as críticas às perspectivas da rotinização como um destino inescapável, alavancado pelas transformações tecnológicas.
} 
predito entre "desigualdade (com maior flexibilidade) $\mathrm{x}$ desemprego (com menor flexibilidade)". Os autores argumentam em favor das mudanças nas relações contratuais de trabalho que, conquanto longe da flexibilidade do modelo norte-americano, teriam produzido um forte crescimento não necessariamente na desigualdade de rendimentos, mas uma desigualdade de segurança no emprego. Gallie e Paugam (2007a) reforçam esta noção ao enfatizarem as distinções entre os modelos de proteção social europeus e as mudanças na estrutura geral do emprego e nas percepções de qualidade e (in) segurança do trabalho ${ }^{32}$.

\subsection{Situando as metrópoles no debate sobre transformações na estrutura ocupacional}

Se o debate acima relatado teve como unidade de análise os Estados Nacionais, ele não deixou de repercutir nas análises sobre as transformações experimentadas pelas grandes metrópoles, notadamente a partir dos anos 1980 e 1990, expressão da centralidade das mesmas na dinâmica econômica e ocupacional no mundo contemporâneo, tal como documentada na seminal e polemica obra de Saskia Sassen, The Global City (1991), em que analisou os casos de Nova Iorque, Londres e Tóquio.

Embora a amplitude desse debate seja bastante extensa, pode-se dizer que, de um modo geral, seu foco estava em compreender os efeitos sociais e espaciais das mudanças econômicas ocorridas em nível global (Marques et al, 2013). Dele nos ocuparemos especialmente no que se refere ao tema das alterações na estrutura ocupacional.

É interessante enfatizar, e pretendemos tratar disso brevemente, que a tendência do debate segue um padrão semelhante ao que viemos discutindo até então. Em primeiro

\footnotetext{
${ }^{32} \mathrm{O}$ debate sobre como o padrão de geração de empregos e a evolução da estrutura ocupacional impactou a desigualdade repercutiu pouco no debate brasileiro. Encontramos uma exceção com Carvalhaes et al (2013) que, utilizando semelhante metodologia de Wright e Dwyer (2003) e de Mouw e Kalleberg (2010), chegaram a dois resultados interessantes. Em primeiro lugar, mostraram como o padrão de empregos no Brasil na última década assumiu o formato de um job upgrading, ou seja, mais empregos criados à medida que se ascende na estrutura ocupacional, puxados principalmente pelos postos de trabalho formais e representando uma mudança qualitativa positiva no mercado de trabalho a se considerar pelo tipo de ocupação criada. Em segundo lugar mostraram que, mais importante do que esse padrão positivo, a queda das desigualdades se deveu mais à diminuição dos retornos associados à escolaridade em virtude das quedas das barreiras educacionais. Ou seja, trata-se mais de uma mudança na composição qualitativa da oferta, embora condicionada por fatores institucionais vinculados às políticas educacionais.
} 
lugar estabelece-se um ponto de partida a partir de uma perspectiva com ambições generalizantes tendo como pano de fundo as grandes transformações econômicas e a internacionalização da economia. Posteriormente, eclodem evidencias mundo afora indicando que especificidades importam (como dinâmicas locais, regulação fundiária, aspectos culturais, etc.), mas importam especialmente quando se consideram os regimes nacionais de bem estar.

Sassen argumenta $^{33}$ no sentido de que, a partir da reestruturação econômica iniciada nos anos 1970, haveria uma tendência de crescente polarização ocupacional nas grandes metrópoles em virtude principalmente de quatro fatores: i) estas cidades passariam a preencher novas funções no capitalismo globalizado, como concentração de atividades de comando e controle, reduzindo o peso das atividades produtivas tradicionais típicas do fordismo; ii) mudança de uma economia industrial para uma economia mais centrada nos setores de serviços, em especial os serviços vinculados aos negócios; iii) crescimento de "serviços inferiores", que dependem do crescimento dos serviços do topo da hierarquia; e iv) crescimento da informalidade, intensificada pelo fluxo migratório e disponibilidade de mão de obra desqualificada (Sassen, 1991, p. 145). Ou seja, as ocupações tradicionais fordistas seriam substituídas por um amplo, variado e desigual setor de serviços, seguindo daí uma polarização ocupacional que se juntaria a uma polarização que se expressaria nas esferas de rendimentos, espaciais, de padrões de consumo e de estilos de vida.

Como se pode notar, embora com nuances, há uma certa semelhança com alguns dos argumentos trabalhados anteriormente, porque é no seio das transformações econômicas e da demanda por trabalho que se encontraria a gênese de tais processos. Não obstante, embora o argumento proponha uma primazia da reestruturação econômica e enfatize os aspectos relativos à demanda por trabalho, o processo de polarização também dependeria de componentes relativos à oferta, como a disponibilidade de migrantes e trabalhadores com menor qualificação.

\footnotetext{
${ }^{33} \mathrm{O}$ que apresentamos aqui é apenas um pequeno resumo da perspectiva dessa autora no que respeita aos pontos que nos interessam. Certamente, sua obra traz inúmeras outras implicações, mas foge largamente aos nossos objetivos revisitá-las.
} 
A proposição de Sassen gerou uma serie de polemicas e foi logo criticada Hamnett (1994). Inspirando-se principalmente nas proposições de Esping-Andersen, para quem os diferentes regimes de welfare atuariam como mediadores do cenário econômico e do mercado de trabalho, o autor argumenta que o aumento da dispersão salarial em Londres dever-se-ia antes a um processo de profissionalização, e não de polarização, de modo que o mesmo poderia ser observado em outras grandes cidades europeias.

\begin{abstract}
Most large non- American cities, growing income inequality is combined with professionalisation of the paid labour force. [...]There is no single global city, only global cities, located within the context of their own particular nation state." We have to bring the state, the structure of civil society and politic al strategy back into discussions of polarisation alongside economic restructuring. (Hamnett, 1996, p. 1428).
\end{abstract}

Outras evidências, também destoando do argumento original de Sassen, foram encontradas por Baum (1999) para Cingapura, onde identifica o papel da regulação estatal em proteger nichos de mercado caracterizados por "bons empregos", o esforço no ajuste salarial e um intenso sistema de qualificação de mão de obra, resultando num incremento dos estratos médios e superiores. Também Vaatovaara e Kortteinen (2003) ao analisarem o caso de Helsink, mostraram que, a despeito de uma forte transição na demanda por trabalho mais qualificado ao estilo skill-biased, as políticas educacionais e de qualificação teriam impedido um processo de polarização ocupacional. Mais do que isso, os autores sublinham como o amplo sistema de welfare contribuiu para que se criasse uma população excedente, constituída pelos trabalhadores menos qualificados a qual, por ser fortemente "desmercantilizada", não se via impelida a ingressar no mercado de trabalho, diminuindo assim os incentivos para a criação de piores empregos na base da estrutura. Entretanto, se não se pode falar de uma polarização ocupacional, argumentam os autores, pode-se reconhecer a emergência de um novo tipo de polarização, qual seja, aqueles que estão dentro e os que estão fora do mercado de trabalho.

Se voltarmos a atenção para o que aconteceu na Região Metropolitana de São Paulo, Marques et al (2013) também não identificam uma tendência de polarização social utilizando as Classes EGP em nível agregado entre os anos de 1991 e 2010. O que se observa é uma redução da base da estrutura (Trabalhadores manuais qualificados e não qualificados) e um crescimento dos trabalhadores não manuais de rotina, dentre os quais os escriturários são a grande maioria. Entretanto, também não se pode reconhecer 
efetivamente uma "profissionalização" pois, apesar da sua contração, os trabalhadores manuais ainda constituem um grupo expressivo na população ocupada.

Também para a RMSP, e utilizando a mesma metodologia de Mouw e Kalleberg (2010), Barbosa e Prates (2013) identificam uma série de vetores contraditórios que influenciaram a dinâmica da desigualdade de renda no mercado de trabalho entre 1981 e 2010. Em primeiro lugar, uma divergência entre o padrão metropolitano e o nacional no que se refere aos fatores ligados aos componentes educacionais na década de 2000 . $\mathrm{Na}$ RMSP, esses fatores atuaram como um vetor de aumento das desigualdades. Além disso, apontam para uma polarização ocupacional do tipo "skill-biased" ao longo da década de 1990, processo que foi revertido ao longo dos anos 2000. Quanto à formalização, novamente os resultados das duas décadas são distintos. Na primeira, um intenso processo de polarização entre os setores formal e informal, ao passo que a partir de 2005 observa-se uma nova inversão, evidenciando a expansão da formalização no período e o peso da dimensão institucional da regulação sobre o mercado de trabalho. A expansão da formalização foi o principal vetor da redução das desigualdades no mercado de trabalho da RMSP na última década.

\subsection{Considerações e apontamentos para a condução do estudo empírico}

Finalmente, poderíamos nos perguntar: "e o que a pobreza tem a ver com isso?" Alegamos que aqueles que poderíamos designar como um estrato social que vivencia uma condição de pobreza (os "pobres”) precisa ser compreendido também no âmbito do mercado de trabalho e do modo pelo qual a estrutura ocupacional disponibiliza uma gama de possibilidades de incorporação. A configuração da pobreza provavelmente será distinta num contexto caracterizado por uma pluralidade de ocupações precárias de outro onde a estrutura ocupacional e salarial sejam mais equânimes. Isto coloca a necessidade de compreender em que medida as dinâmicas da estrutura ocupacional - em especial aquelas que se encontram na sua base - se mostram mais ou menos propensas a produzir diferentes posições no interior da estrutura social, condicionando o acesso à renda e ao bem estar.

Mas este é apenas um dos lados da questão. Como esperamos ter mostrado até então, a própria dinâmica ocupacional responde de diferentes maneiras não apenas às 
transformações na oferta e na demanda, mas também à configuração institucional do mercado de trabalho. Não por acaso, países que experimentaram mudanças semelhantes no tocante ao desenvolvimento tecnológico e à composição da força de trabalho após os anos 1970 apresentaram padrões tão diversos de evolução da estrutura ocupacional. Naqueles países onde o traço liberal da proteção social é mais marcante, o mercado de trabalho produziu ao longo dos últimos 30 anos uma vasta proporção de ocupações na base da distribuição, ao passo que, principalmente nos países escandinavos (modelo socialdemocrata) tais ocupações tiveram baixo aumento relativo.

Tendências semelhantes são encontradas quando as grandes cidades são tomadas como unidade de análise. O processo de polarização ou de constante aumento na demanda por maior qualificação, percebido por alguns autores como uma sorte de destino inevitável do capitalismo financeirizado, não se generalizou, nem tampouco se sobrepôs às diferenças institucionais. E se é certo que, de um modo geral, a demanda nos países desenvolvidos tendeu a se virar contra os menos qualificados - aumentando sua chance relativa de vivência da e na pobreza -, a intensidade desta virada depende largamente do comportamento do mercado de trabalho e de como as instituições o formatam, como viemos salientando.

Chegados a este ponto, talvez valesse à pena recapitular o fio do argumento antes de darmos um novo passo em direção à analise empírica.

Assim, no primeiro capitulo, a relação entre o processo de construção institucional do mercado de trabalho e da proteção social no Brasil, capitaneados pela temática da expansão do assalariamento, foi um dos pontos desenvolvidos. Como diagnosticado pela literatura trabalhada, estes fatores resultaram em um sistema de proteção estratificado e excludente, justamente porque associado à forma como as ocupações foram criadas e legitimadas, em especial nos setores urbanos e modernos da economia, fornecendo os parâmetros para temas como a marginalidade e a informalidade.

Ao longo dos anos 1990, afirmamos ter tido lugar uma sorte de duplo movimento. De um lado, a retração econômica seguida do desassalariamento formal e da flexibilização da regulação do trabalho, resultando em um novo significado da própria instabilidade ocupacional e refletindo nas perspectivas sobre pobreza que se renovaram no período. Por outro, na esteira da Constituição de 1988, começara a se ampliar o escopo da 
proteção social não contributiva e desvinculada do trabalho, embora esta tenha se mostrado insuficiente para amortecer os efeitos das transformações no mercado de trabalho. Nos 2000, assistimos a uma continuidade da fluidez do mercado, mas agora sob um ciclo de expansão econômica e de crescimento do assalariamento formal, ao mesmo tempo em que foram expandidas consideravelmente as políticas sociais na base da pirâmide, especialmente aquelas dirigidas aos mais pobres.

No segundo capítulo retratamos a literatura que enfatizou como as transformações da economia (leia-se renovação tecnológica e abertura dos mercados) a partir da década de 1970 e as mudanças nos componentes relativos à oferta de trabalho resultaram em vetores de transformação da estrutura ocupacional. Estes vetores, entretanto, são calibrados pela extensão, escopo e qualidade dos sistemas de welfare, que atuam como mediadores institucionais e formatadores mesmo do funcionamento dos mercados de trabalho. Ao final, tentamos estabelecer um ponto de contato entre as perspectivas trabalhadas e aquelas que se voltaram para apontar as transformações das grandes metrópoles no contexto.

O desafio que se coloca a partir de agora é como articular estes temas trabalhados até aqui de modo a fornecer bases teóricas que permitirão elaborar hipóteses que pretendemos sujeitar à verificação adotando a RMSP como estudo de caso. Não se pretende, obviamente, usar os resultados acerca da RMSP como caso ilustrativo do que se passa no Brasil como um conjunto; entretanto, é certo crer que a região guarda algumas características que a tornam um caso especialmente rico, através do qual se pode travar um diálogo com a literatura até aqui discutida.

Um primeiro aspecto é que a RMSP esteve sujeita ao legado histórico fornecido pelo sistema de proteção social vinculado ao mercado de trabalho formal. Mais do que isso, por todo o sistema de regulação de trabalho e as mudanças que lhe acompanham, visto que tais institucionalidades são nacionais, e não locais. Desta forma, pode-se dizer que, do ponto de vista dos marcos legais do sistema de "cidadania ocupacional", posteriormente de relativa expansão que culminou com a Constituição de 1988 e, por fim, a flexibilização dos anos 1990, por serem nacionais, não distinguem a RMSP do 
ponto de vista da legislação ${ }^{34}$. Quanto à expansão da proteção social e das políticas sociais de combate à pobreza a partir da década de 1990, há uma sorte de meio termo, porque embora os marcos legais sejam nacionais, sua eficiência e eficácia dependem em larga medida das dinâmicas estaduais e municipais. Além disso, os estados e municípios tem um certo grau de autonomia para formular e implementar suas própria políticas locais, o que lhes distingue do resto do Brasil. Embora cientes dessas especificidades locais quanto a estes dois últimos pontos, não nos ocuparemos deles e preferimos utilizá-los como ressalvas.

De outro lado, foi justamente nessa região em que os setores modernos da indústria e dos serviços, juntamente com o processo expansão do assalariamento formal, mais se expandiram e se consolidaram historicamente. Não obstante, é um mercado de trabalho extremamente dinâmico e fluido, com elevadas taxas de rotatividade e que sofreu fortemente com as transformações recentes. Mas, justamente pela sua centralidade e vigor, foi pioneiro no processo de reestruturação dos anos 1990 e central para a retomada do crescimento da economia nacional na década seguinte. Ou seja, o mercado de trabalho da RMSP constitui um bom caso donde poderemos observar de que maneira as transformações ocorridas na estrutura ocupacional após os anos 1990 - em especial os padrões de geração de emprego nas duas últimas décadas - se associam mais ou menos ao comportamento e à configuração da pobreza, tendo como pano de fundo o sistema de proteção social.

No capítulo seguinte, apresentamos mais alguns dados das transformações do mercado de trabalho na RMSP que permitirão tentar traçar um paralelo entre a literatura até aqui abordada e formulação das hipóteses que pretendemos desenvolver. Posteriormente, apresentamos a metodologia adotada e os resultados empíricos, a fim de verificar ou não as hipóteses formuladas. Ao fim tecemos algumas considerações.

\footnotetext{
${ }^{34}$ Certamente não estamos afirmando aqui que a RMSP é ilustrativa do cenário nacional, ainda mais se tivermos em mente que, do ponto de vista histórico, os trabalhadores rurais estiveram por muito tempo excluídos do sistema de proteção social. Estamos apenas afirmando que não há nada de muito relevante, do ponto de vista da legislação, e não do fato de sua expansão industrial e do assalariamento, que a especifique em relação a outros contextos.
} 


\section{PADRÕES DE EVOLUÇÃO DA ESTRUTURA OCUPACIONAL E POBREZA NA REGIÃO METROPOLITANA DE SÃO PAULO}

\subsection{Retomando as mudanças e continuidades no mercado de trabalho da RMSP}

A Região Metropolitana de São Paulo passou por profundas transformações na sua estrutura produtiva e na demanda por trabalho desde o início dos anos 1990; transformações sintonizadas com processos que, em suas grandes linhas, foram referidos nos capítulos precedentes.

Como mostramos no primeiro capítulo (Gráfico 2 - Participação relativa dos setores de atividades econômicas (ISIC) no volume total de empregos, RMSP; 1991-2010), houve um forte incremento do setor de serviços na participação relativa no volume total de empregos, embora em maior intensidade relativa na primeira década. O que aquele gráfico não mostra, entretanto, é que se tomarmos o saldo de geração de empregos nas duas décadas, vemos que o setor de serviços foi o grande responsável pelos novos postos criados, mas agora em maior intensidade nos 2000 do que nos 1990. A despeito disso, o que o Gráfico 4 abaixo também mostra é que a geração de empregos em ambas as décadas dependeu quase que exclusivamente desse setor e, como bem se pode notar, a indústria não aparece abaixo justamente porque o seu saldo é negativo tanto ao longo da década de 1990 como na de 2000. 
Gráfico 4 - Participação relativa dos setores de atividade econômica no saldo de empregos criados, RMSP; 1991-2010

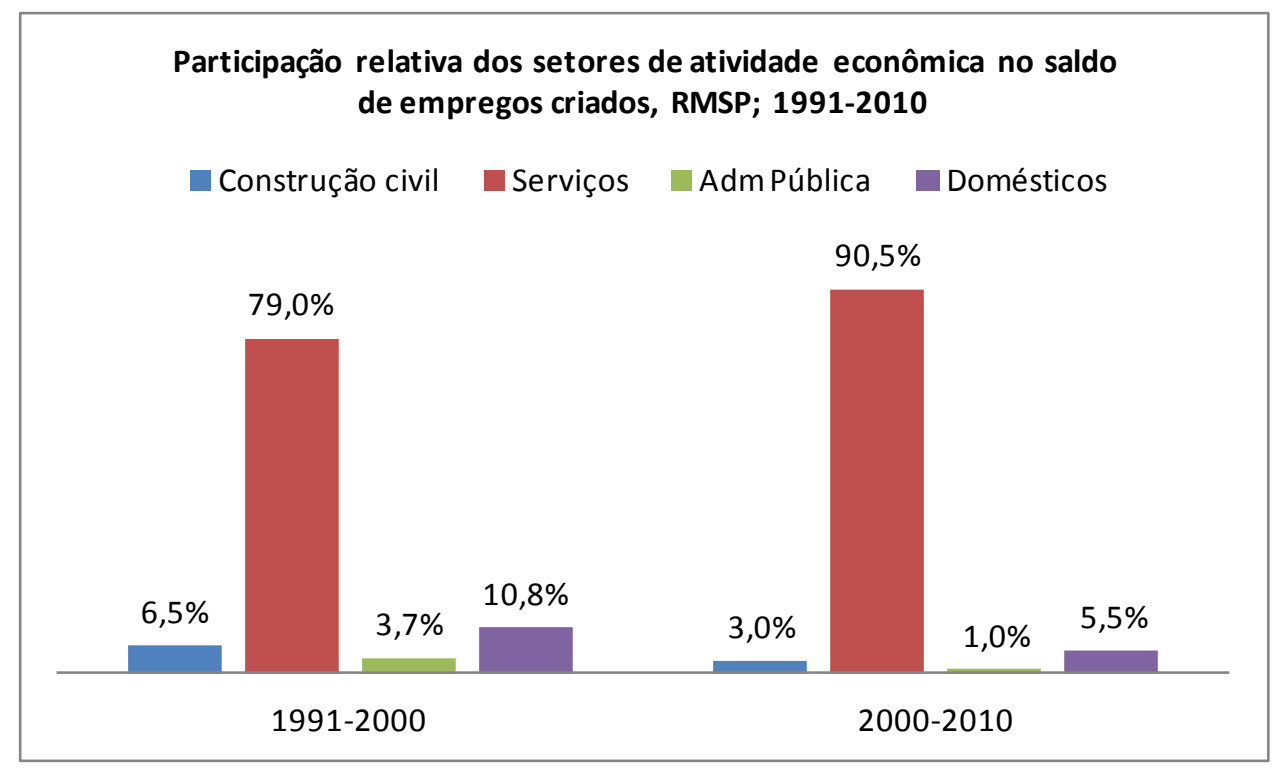

Fonte: Microdados dos Censos Demográficos (IBGE), 1991, 2000 e 2010. Elaboração própria.

Assim, consideramos ser pertinente explorar um pouco mais as transformações no interior do setor de serviços, de modo a identificar algumas dinâmicas que subsidiarão a formulação das nossas hipóteses.

Se vimos que o setor de serviços cresceu em ambas as décadas, o seu crescimento interno (ou seja, o crescimento dos seus subsetores) foi mais heterogêneo na primeira, como mostrou o Gráfico 3. Na década de 2000, ele se deu quase que exclusivamente nos subsetores de "Comércio e distribuição" e "Serviços prestados a empresas", evidenciando, este ultimo em especial, o lado terceirizado do mercado de trabalho da metrópole. A fim de melhor identificar tais alterações, vamos nos deter rapidamente sobre as transformações desses subsetores, destacando especialmente o quão heterogêneos são em termos de variação de salários, ou seja, na sua capacidade de dar, aos seus trabalhadores, acesso a rendimentos que assegurem a reprodução.

A Tabela 2 abaixo apresenta os rendimentos médios e relativos nos subsetores dos serviços entre 1991 e 2010, e o Gráfico 5 apresenta o Coeficiente de Variação dos salários para cada um deles ${ }^{35}$. Podemos notar algumas mudanças importantes que, em

${ }^{35}$ O Coeficiente de Variação é uma medida de dispersão que permite comparar diferentes distribuições. Seu valor é dado pela divisão do desvio-padrão pela média. 
primeira instância, sugerem movimento em direção a maior heterogeneidade interna. Em primeiro lugar, vemos que a dispersão salarial sobe consideravelmente na primeira década, para se manter praticamente estável ao longo dos 2000. Por outro lado, se na primeira década esta subida parece ter sido puxada principalmente pelos subsetores de "Comércio e distribuição", "Serviços prestados a empresas" e "Educação", na década seguinte é apenas nos setores "Serviços financeiros" e "Saúde e serviços sociais" que o $\mathrm{CV}$ tem seu valor aumentado. Isto implica dizer que as duas décadas foram distintas no que se refere ao comportamento de cada uma das atividades econômicas e, mais do que isso, reforça a ideia de um aumento da heterogeneidade do setor de serviços como um todo a partir da década de 1990, embora com nuances que cabe destacar.

Vejamos os detalhes relativos à renda do salário. Na primeira década, percebemos um forte incremento da renda nos "Serviços financeiros" e nos "Serviços prestados a empresas", enquanto que quase todos os outros subsetores têm queda no rendimento relativo, em especial "Hotelaria e Restaurante", um dos que mais cresceu no período. Também vemos a forte queda dos salários relativos do setor de Saúde e Serviço Social, retratando a entrada do capital privado no setor. O comportamento desse tipo de serviços é fator crucial para compreendermos a dinâmica da estratificação social e dos tipos de empregos que se criam, em especial na base da pirâmide (Esping-Andersen, 1990; 1999). Sua expansão via mercado implica um duplo movimento. Ao mesmo tempo em que mercantiliza o acesso e é distribuído desigualmente, por depender da capacidade de consumo das famílias, esse movimento tende a alavancar a polarização ocupacional (o exemplo clássico é a maior diferença de salários entre as ocupações de médico e enfermeiro no setor privado do que no publico). O resultado desse vetor, como não poderia deixar de ser, é tanto uma maior diferenciação da estrutura de classes ocupacionais, ao mesmo tempo em que um aumento das distancias entre elas. O contra exemplo, por outro lado, é quando esses serviços se dão pela via não mercantil, ou seja, pelo provimento direto via Estado. Nesse caso, os empregos gerados são menos desiguais - porque produzidos no interior do serviço público - diminuindo as ocupações de base e minimizando o efeito da desigualdade de poder de consumo. Este primeiro resultado pode ser visto como um fato que subsidia a ideia de um vetor de polarização da estrutura ocupacional na década de 1990. 
Entretanto, o efeito da diferenciação salarial neste setor só se fez sentir na década seguinte, como mostra o gráfico. O CV em 2010 é quase o dobro do que era em 1991 e 2000, retratando uma maior diferenciação interna. Por outro lado, vemos que no setor de “Educação”, já ao longo da década de 1990 este processo havia se instalado.

O que é também importante nesses dados é o forte crescimento da dispersão salarial nos dois subsetores que mais geraram em empregos nas duas décadas: "Comércio e distribuição" e "Serviços prestados a empresas". Essa dispersão cresce consideravelmente ao longo da década de 1990 para, na seguinte, sofrer uma leve queda. Novamente, vemos que este constituiu outro vetor para a polarização ocupacional no mercado de trabalho nos 1990; mas, igualmente é de se notar uma contra-tendência nesse processo, mesmo que não muito acentuada, nos 2000.

Tabela 2 - Rendimentos médios absolutos e relativos nos subsetores dos serviços,

RMSP; 1991-2010

\begin{tabular}{|c|cc|cc|cc|}
\hline Ano & \multicolumn{2}{|c|}{1991} & \multicolumn{2}{c|}{2000} & \multicolumn{2}{c|}{2010} \\
\hline Sub setor & Renda Média & $\begin{array}{c}\text { Renda } \\
\text { Relativa }\end{array}$ & Renda Média & $\begin{array}{c}\text { Renda } \\
\text { Relativa }\end{array}$ & Renda Média & $\begin{array}{c}\text { Renda } \\
\text { Relativa }\end{array}$ \\
\hline Comércio e distribuição & 2199,19 & $91,4 \%$ & 2270,70 & $90,2 \%$ & 1743,18 & $79,2 \%$ \\
Hotelaria e restaurante & 2071,96 & $86,1 \%$ & 1686,72 & $67,0 \%$ & 1366,86 & $62,1 \%$ \\
Transporte e comunicação & 2157,56 & $89,7 \%$ & 2250,74 & $89,4 \%$ & 1995,05 & $90,6 \%$ \\
Serv Financeiros & 2740,07 & $113,9 \%$ & 3709,77 & $147,4 \%$ & 3710,42 & $168,5 \%$ \\
Serv prestados a empresas & 2844,50 & $118,2 \%$ & 3347,08 & $132,9 \%$ & 2654,07 & $120,5 \%$ \\
Educação & 2101,31 & $87,3 \%$ & 2228,34 & $88,5 \%$ & 2190,77 & $99,5 \%$ \\
Saúde e serviço social & 3017,14 & $125,4 \%$ & 2623,83 & $104,2 \%$ & 3026,50 & $137,4 \%$ \\
\hline Média & 2406,44 & $100 \%$ & 2517,65 & $100,0 \%$ & 2201,94 & $100 \%$ \\
\hline
\end{tabular}

Fonte: Microdados dos Censos Demográficos (IBGE), 1991, 2000 e 2010. Elaboração própria. 
Gráfico 5 - Gráfico de Variação da Renda do trabalho nos subsetores de serviços, RMSP; 1991-2010

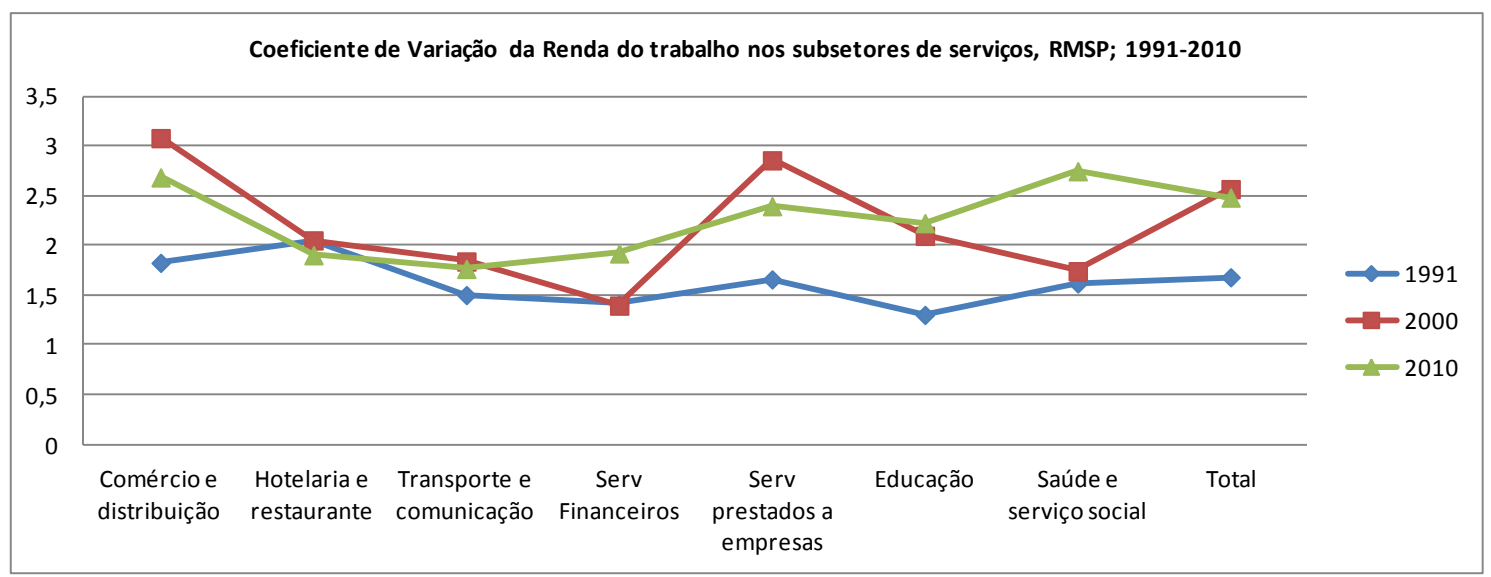

Fonte: Microdados dos Censos Demográficos (IBGE), 1991, 2000 e 2010. Elaboração própria.

Tendo sumarizado as principais tendências que podem ser vislumbradas pelo âmbito da demanda, o nosso próximo passo será observar o que se passa do outro lado da relação mercantil em jogo no mercado de trabalho, examinando as principais mudanças na estrutura da oferta de força de trabalho que, como visto, cumpre papel igualmente determinante no entendimento dos elos entre pobreza e mercado de trabalho.

\subsection{Oferta e estrutura salarial}

É inegável que o perfil da oferta de trabalho tem experimentado significativas mudanças ao longo das últimas décadas, tanto na RMSP quanto no Brasil. Do ponto de vista demográfico, fortes quedas nas taxas de crescimento populacional e mortalidade infantil vêm impulsionando alterações na pirâmide etária em virtude do envelhecimento da população ${ }^{36}$. Este movimento, ainda em curso, tem ampliado sistematicamente os grupos etários em idade ativa. Apenas entre 1991 e 2010, a proporção de indivíduos entre 16 e 65 anos na RMSP saltou de $63,8 \%$ para 70,0\%, resultando num aumento significativo da oferta potencial de trabalho e criando uma maior pressão sobre o mercado.

\footnotetext{
${ }^{36}$ Para mais informações ver: www.ibge.gov.br
} 
Igualmente importantes foram as mudanças na composição por sexo, influenciadas pela entrada cada vez mais intensa das mulheres no mercado de trabalho, num movimento de mercantilização da força de trabalho feminina. A esse respeito os números são impactantes. Entre 1991 e 2010, a taxa de participação das mulheres acima de 15 anos teve um incremento de aproximadamente 15,0 pontos percentuais, o dobro da queda observada para os homens. Isto fez com que a PEA, que em 1991 tinha 2 vezes mais homens do que mulheres (63,2\% contra 36,8\%), chegasse a 2010 com uma composição quase equânime. Ou seja, alterou-se profundamente a estrutura da oferta, tanto do ponto de vista da intensidade com que homens e mulheres vão ao mercado, como, e por isso mesmo, da própria composição dos trabalhadores em termos de sexo.

Por ora, contudo, interessa-nos enfocar a evolução geral dos níveis de escolaridade e os rendimentos do trabalho associados a cada estrato. No que respeita à escolaridade, em 1991 eram muito baixos os seus níveis mesmo na RMSP; nesse momento, mais da metade da PEA não tinha sequer 8 anos de estudo completos. Em 2010, embora uma melhoria tivesse ocorrido, este contingente pouco escolarizado segue sendo o segundo grupo mais representativo, representando 27,0\% da PEA, atrás das pessoas com Ensino Médio completo $(34,1 \%)$.

Os retornos educacionais apresentaram forte queda nas últimas décadas, na RMSP como em todo o Brasil, especialmente para os trabalhadores com nível superior. Entretanto, chama atenção a recomposição da estrutura de rendimentos quando observamos cada um dos estratos e, especialmente o que se apresenta no ano de 2010. Essa nova realidade fica ainda mais intrigante quando combinamos, na observação da Tabela 3, um olhar sobre as tendências nos rendimentos e sobre as tendências na desocupação. Assim, se ao longo dos anos 1990 apenas o estrato superior apresentou crescimento da média salarial, nos 2000 o cenário se inverte completamente. Aqueles com ensino fundamental incompleto foram os únicos que não viram o seu rendimento médio na ocupação decair, ao mesmo tempo em que sua taxa de desocupação é mais baixa que a dos dois estratos subsequentes (Médio incompleto e médio completo), algo completamente novo no período. 
Tabela 3 - Indicadores do mercado de trabalho por escolaridade, RMSP; 1991-2010

\begin{tabular}{|c|c|c|c|c|c|c|c|c|c|}
\hline \multirow{2}{*}{ Escolaridade } & \multicolumn{3}{|c|}{$\%$ da PEA } & \multicolumn{3}{|c|}{ \$ médio na ocupação principal } & \multicolumn{3}{|c|}{ Tx de desocupação da PEA } \\
\hline & 1991 & 2000 & 2010 & 1991 & 2000 & 2010 & 1991 & 2000 & 2010 \\
\hline Fundamental Incompleto & 55,7 & 34,9 & 27,8 & 1344,93 & 1102,94 & 1135,02 & 7,8 & 22,3 & 7,9 \\
\hline Fundammental completo & 16,0 & 28,3 & 19,8 & 1571,04 & 1523,37 & 1250,74 & 6,8 & 22,8 & 11,7 \\
\hline Médio Completo & 18,4 & 25,9 & 34,0 & 2722,50 & 2246,55 & 1649,09 & 4,5 & 15,7 & 8,5 \\
\hline Superior Completo & 10,0 & 10,9 & 18,3 & 5859,83 & 6231,10 & 4871,80 & 2,5 & 5,3 & 3,2 \\
\hline
\end{tabular}

Fonte: Microdados dos Censos Demográficos (IBGE), 1991, 2000 e 2010. Elaboração própria.

É impossível não associar a manutenção do rendimento do estrato educacional inferior verificada entre 2000 e 2010 ao crescimento real do salário mínimo resultante da política de valorização posta em prática na segunda metade dos anos 2000. Mas o fato deve ser compreendido também a partir dos distintos padrões de evolução da estrutura ocupacional nas duas décadas. Já havíamos observado anteriormente que o estrato salarial de até 2 salários mínimos - que absorve aproximadamente $3 / 4$ das pessoas com Ensino Fundamental Incompleto - foi responsável por 80,0\% da criação de empregos nos 2000 , contra pouco mais de 60,0\% nos 1990; isso sem contar o número absoluto de trabalhadores que ingressaram em ocupações desse tipo (1,35 milhão e 870 mil, respectivamente). Além do mais, o crescimento da taxa de formalização ocorrida na última década para o estrato educacional inferior foi de pouco mais de $40,0 \%$, contra $25,0 \%$ da média geral.

No lado oposto da estrutura educacional, observamos, entre 1991 e 2000, um aumento da demanda relativa entre os mais qualificados. Não apenas a taxa de desocupação entre esses é a que menos se elevou seguindo a média geral, como também foi o único grupo que teve crescimento médio dos rendimentos. Em 2010, embora sua taxa de desocupação seja a mais baixa (o que de resto ocorre para todos os grupos), a queda no rendimento médio é de mais de 20,0\% (de $\mathrm{R} \$ 1360,00$ ).

Isso nos permite concluir que o mercado de trabalho da metrópole paulista, ao longo dos anos 2000, se mostrou mais atrativo para os menos qualificados do que fora nos 1990; e isso se verifica tanto do ponto de vista das suas possibilidades de inclusão, quanto do ponto de vista dos rendimentos daqueles já incluídos. Com o enxugamento de boa parte das ocupações intermediárias e mais elementares nos 1990, aquelas que restaram parecem ter sido preenchidas na sua maioria pelos estratos educacionais médios. Já nos 
2000, o processo muda de direção, incorporando um elevado contingente de pessoas menos qualificadas e diminuindo os retornos nos níveis escolares mais altos.

Tendo tais aspectos em vista, e em diálogo com a literatura tratada até aqui nos capítulos precedentes, é que nos foi possível formular nossas hipóteses de pesquisa, que são apresentadas na seção seguinte.

\subsection{Formulação das hipóteses}

Apesar das especificidades que caracterizam a Região Metropolitana de São Paulo, acreditamos poder estabelecer alguns pontos de contato com achados da literatura tratada no capítulo precedente.

Assim, e como ressaltado no capítulo 1, embora não se possa dizer de um processo de “desindustrialização" da região, pode-se dizer de uma forte transição do tipo setorial de ocupação, do industrial para o de serviços, embora em 1991 este último já fosse mais representativo (em torno de $30,0 \%$ e $40,0 \%$, respectivamente). Entretanto, o crescimento relativo do setor de serviços ${ }^{37}$ foi muito mais acentuado na primeira década sob análise, além do fato de que a geração de empregos no interior dos seus subsetores foi mais diversificada nos anos 1990 do que nos $2000^{38}$; nuances podem ser igualmente percebidas em relação às duas décadas no que concerne também à heterogeneidade salarial interna dos setores. Nesse sentido, mostramos o maior aumento da dispersão salarial no setor de serviços na primeira década, e sugerimos alguns vetores dessa polarização salarial e ocupacional.

Diante dessas considerações, tomamos como pano de fundo os seguintes fatos para a formulação das hipóteses referentes à década de 1990: i) a flexibilização das relações trabalhistas; ii) a elevada taxa de desocupação no período; iii) o fato de que os menos escolarizados foram os mais afetados com a reestruturação micro-organizacional; e iv) o

\footnotetext{
${ }^{37}$ Conforme se pode ver no Gráfico 2 - Participação relativa dos setores de atividades econômicas (ISIC) no volume total de empregos, RMSP; 1991-2010 apresentado no primeiro capitulo.

${ }^{38} \mathrm{Na}$ década de 2000, os empregos gerados no setor de serviços foram basicamente nos subsetores de "comércio e distribuição" e "serviços prestados a empresas", enquanto que nos 1990 os subsetores de "Transporte e comunicação" e "educação e serviços sociais" tiveram um peso relativo maior que na década seguinte. Ver Gráfico 3 - Total de empregos gerados nos subsetores de "Serviços", RMSP; 19912010 do primeiro capítulo.
} 
ainda reduzido escopo da proteção social, embora em movimento de expansão; v) desvalorização real do salário mínimo entre 1991 e 2000; vi) o aumento das taxas de pobreza na década.

Na década de 2000, os principais fatos estilizados que temos em mente para formular as hipóteses são: i) continuidade da fluidez do mercado e da flexibilização dos contratos, embora com a expansão da cobertura do seguro desemprego; ii) redução das taxas de desemprego, informalidade e pobreza; iii) crescimento menos heterogêneo dos subsetores de serviços, concentrados mais nos subsetores de "serviços prestados à empresa" e "comércio e distribuição"; iv) política de valorização real do salário mínimo; v) expansão maciça dos estratos salariais inferiores ${ }^{39}$; vi) expansão da proteção social na base da pirâmide, em especial aos mais pobres.

A partir desses fatos e subsidiados pela literatura trabalhada, formulamos uma hipótese mais geral, que se desdobrará em seguida:

Hipótese 1 (Geral): As duas décadas foram distintas no que concerne ao padrão de evolução da estrutura ocupacional e essas diferenças ajudam a explicar o comportamento da pobreza no período.

Para a década de 1990, especificamos:

Hipótese 2.0: Ao longo dos anos 1990 teve lugar um processo de polarização da estrutura ocupacional que se deve principalmente a: i) mudanças na demanda por trabalho (diminuição da demanda relativa por trabalho menos qualificado na base e aumento da demanda pelos mais qualificados); ao que se associa ii) forte queda dos empregos industriais e crescimento da heterogeneidade na geração de empregos no interior do setor de serviços; iii) flexibilização das relações de trabalho ao longo da década. ${ }^{40}$

Hipótese 2.1: Este padrão de evolução da estrutura ocupacional entre 1991 e 2000 contribuiu para a elevação da pobreza no período em virtude de: i) existência de ocupações mal remuneradas na base da estrutura ocupacional; ii) o baixo valor

\footnotetext{
${ }^{39}$ Como observamos na Tabela 1 - Estrutura salarial da RMSP, 1991-2010, Capítulo 1, o crescimento do estrato salarial de pessoas com até 1 SM entre 2000 e 2010 foi de $27,5 \%$.

${ }^{40}$ Este último ponto não é passível de ser verificado empiricamente com os dados de que dispomos. Entretanto, encontra respaldo na literatura trabalhada e o tomaremos como pano de fundo contextual da época.
} 
relativo do salário mínimo no ano 2000; iii) da escassa capilaridade da proteção social aos mais pobres na base da pirâmide; iv) a contração da demanda de trabalho para os menos qualificados, ao que se associa a própria composição educacional da oferta.

Do ponto de vista teórico, a confirmação dessas hipóteses, mesmo que parcial, permitirá argüir que houve um movimento de polarização skill-biased em contexto de flexibilização das relações trabalhistas e escassez da proteção social na base da pirâmide. Ao qualificar este movimento, ao modo da literatura antes revista, como de tipo skill-biased, não estamos querendo sugerir que o processo aqui ocorrido tenha tido mesma intensidade de incorporação tecnológica que aquela manifesta nos países desenvolvidos onde foi diagnosticada (retomando os termos dos autores) uma "skill biased technological change"; a isso deve-se agregar as diferenças consideráveis tanto nos níveis educacionais da oferta, como da própria estrutura ocupacional sobre a qual essas mudanças impactavam no ponto de partida, em cada um dos casos. Estamos supondo, no caso da RMSP, que um certo grau de incorporação tecnológica, que se seguiu com a reestruturação produtiva, teria aumentado a demanda relativa por trabalhadores mais qualificados no topo da hierarquia ocupacional.

Quanto à proteção social, cabe salientar dois pontos. Em primeiro lugar, o efeito da flexibilização das relações de trabalho, que diminuiu os custos de demissão e tornou dispensável um amplo contingente de trabalhadores, justamente em um contexto de baixa geração de empregos. No que concerne à base da pirâmide, em especial aos mais pobres, ressaltamos que a despeito de uma relativa expansão da proteção social que teve lugar a partir de meados dos anos 1990, sua capilaridade ainda era bastante reduzida, como já ressaltamos.

Já para os anos 2000, formulamos:

Hipótese 3.0: Os anos 2000 são marcados por uma tendência de crescimento da base da estrutura ocupacional, de virtude de: i) mudança na natureza da demanda por qualificação (cresce a demanda pelos menos qualificados e cai a demanda pelos mais qualificados), a qual está associada: ii) ao forte crescimento dos subsetores de 
serviços onde são menores os salários (em especial comércio e distribuição) ${ }^{41}$; iii) à continuidade da fluidez do mercado em termos de flexibilidade das relações de trabalho ${ }^{42}$.

Hipótese 3.1: Este padrão de evolução da estrutura ocupacional contribuiu para a redução da pobreza no período em virtude: i) do próprio crescimento da base da estrutura, com incorporação de um amplo contingente de trabalhadores menos qualificados que estavam excluídos do mercado de trabalho; ii) da valorização real do salário mínimo e (iii) da ampliação da cobertura da proteção social aos mais pobres, que se fez tanto associada à expansão do assalariamento formal como a ampliação da cobertura dos programas de transferência de renda.

A confirmação dessas hipóteses nos permitirá arguir que a queda da pobreza que teve lugar na RMSP ao longo dos anos 2000, embora esteja intimamente relacionada à queda do desemprego, à valorização do salário mínimo e à formalização (como inúmeros autores já trataram de destacar) - elementos que dizem diretamente do comportamento dos fatores de oferta e demanda, ou seja da dinâmica interna ao mercado de trabalho -, também se associa ao padrão de geração de empregos que se estabeleceu no período traço que diz da reconfiguração da dinâmica de transformação na organização da produção nas firmas e seus efeitos na estrutura ocupacional.

Do ponto de vista teórico, isso nos instiga à discussão sobre o que condiciona tal padrão e sugere, em primeira instancia, uma sorte de expansão do mercado de trabalho via ocupações de base e instáveis (como mostramos no primeiro capitulo), porque fortemente centradas em serviços pouco dinâmicos e de baixo valor agregado. Mas pretendemos travar esta discussão tendo à mão os resultados empíricos mais adequadamente operacionalizados, o que dará maior robustez ao que se argui.

Entretanto, antes de apresentarmos a metodologia, os resultados e a pertinência empírica das hipóteses sugeridas, o que terá lugar na próxima seção, convém tecer algumas considerações relativas ao que consideramos, no estudo empírico, como uma proxy do sistema de proteção social aos mais pobres, ou, tal como denominaremos doravante -

\footnotetext{
${ }^{41}$ Evidente no crescimento dos estratos salariais inferiores, conforme se pode ver na Tabela 1 - Estrutura salarial da RMSP, 1991-2010, cap 1.

${ }^{42}$ Ver nota 41 acima.
} 
inclusive por questões práticas, de mensuração - como a "esfera de atuação da política de proteção social de combate à pobreza".

Por "esfera de atuação da política de combate à pobreza" estamos nos referindo àqueles indivíduos pertencentes ao estrato social cuja renda familiar per capita torna-os elegíveis ao cadastramento no CadÚnico ${ }^{43}$ (ou seja, 1/2 salário mínimo, R \$255,00 em valores de 2010) e ao recebimento do benefício do Programa Bolsa Família ( $\$$ 120,00 per capita em valores de 2010). Os rendimentos de 1991 e 2000 foram deflacionados para valores de julho de $2010^{44}$.

Desta forma, para identificar aqueles indivíduos que poderiam estar compreendidos na "esfera de atuação da política social de combate à pobreza" nos anos de 1991 e 2000, adotamos o mesmo critério que era utilizado pelo governo federal em 2010. Vale dizer, o que estamos fazendo é assumir os parâmetros que definiam a esfera da política de combate à pobreza em 2010 e aplicá-los aos anos de 1991 e 2000, de modo a permitir uma comparação entre os anos. Acreditamos que, assim, minimizamos o peso que as transformações econômicas poderiam ter sobre os resultados (valores de salário mínimo, inflação, etc.), como também as transformações na própria política. Embora estejamos cientes da limitação dessa proposta, o que nos propusemos a fazer para minimizar esta limitação foi tomar, no ano de 2010, os beneficiários do PBF como aqueles recobertos pela política de proteção social de combate à pobreza.

\subsection{Metodologia para análise da evolução da estrutura ocupacional e resultados preliminares}

Para a análise da evolução da estrutura ocupacional da Região Metropolitana de São Paulo, utilizamos metodologia semelhante à que foi aplicada por Wright e Dwyer (2003), Goos e Maning (2009) e Fernandez-Macíaz (2012), dentre outros, para a avaliação das tendências nos Estados Unidos e na Europa. Trata-se de um procedimento

\footnotetext{
${ }^{43}$ Ver seção 1.3 do capitulo 1.

${ }^{44}$ A opção por utilizar valores de 2010 se dá pelo fato de que, por estarmos adotando a linha de pobreza institucional (estabelecida pelo Governo Federal), distorceríamos os dados se os deflacionássemos para 2013. Isso porque a linha de pobreza do governo não se atualiza com a inflação, de modo que poderíamos estar considerando como "elegíveis" aqueles que de fato não o eram no período.
} 
relativamente simples de hierarquizar distintas ocupações de modo a torná-las comparáveis em mais de um ponto no tempo.

Em primeiro lugar, fizemos um cruzamento entre o código ocupacional do IBGE traduzido para o código Isco-88 (código da ocupação: Isco-88 3 dígitos) e "Setor de atividade econômica" (Isic - 1 dígito) para todos os anos analisados. Desta forma, é gerado um total potencial de ocupações, que corresponde justamente à multiplicação do número de ocupações "Isco 3 dígitos" x "Isic 1 dígito".

Tendo em vista as alterações na estrutura ocupacional, optamos por criar um único banco $\left(1991,2000\right.$ e 2010) ${ }^{45}$. Embora a grande maioria das ocupações esteja presente em todos os anos, algumas existem apenas em um ou em dois desses anos. Assim fazendo, contornamos o problema e podemos comparar com maior confiabilidade as alterações na estrutura ocupacional, sem perder ocupações ao longo do período. Se tivéssemos optado por fixar um ano-base (por exemplo, o de 1991), teríamos que reduzir a estrutura ocupacional dos outros dois anos às classificações ocupacionais do primeiro ano. Sendo assim, perderíamos de vista justamente o fenômeno que nos interessa observar, qual seja, o das transformações na estrutura ocupacional, visto que em virtude dos limites colocados pelas diferenças nas classificações ocupacionais, não poderíamos identificar tais mudanças.

Feito isso, as ocupações foram ordenadas de acordo com a mediana da renda e distribuídas em quintis, sendo que as ocupações-setor com menores rendas se situam na base da distribuição, enquanto que aquelas com maiores rendas se situam no quintil superior. Devemos ressaltar, no entanto, que como os quintis de ocupação foram criados a partir de um "banco único" com os dados de 1991, 2000 e 2010, as mudanças observadas nas seções a seguir espelham, sobretudo, mudanças em relação à média geral do período. Explicamos. Quando tomamos este "banco único" e identificamos os quintis de ocupação, é como se estivéssemos criando um cenário hipotético que compilasse, num ponto fixo no tempo, as estruturas ocupacionais dos três anos analisados. As diferenças entre 2000 e 1991, por exemplo, irão espelhar quão intensa

\footnotetext{
${ }^{45}$ Ao final da presente dissertação, apresentamos um anexo metodológico que esclarece alguns pontos relativos ao tratamento das variáveis de ocupação nos dados censitários de 1991, 2000 e 2010, bem como a opção por criar um "banco único" para os respectivos anos.
} 
foram as mudanças a partir da média dos dois decênios. $\mathrm{O}$ mesmo vale para o período 2000-2010.

Posto isso, esclarecemos que, como a unidade de análise é a ocupação, podemos avaliar o saldo (crescimento, manutenção ou decréscimo) dos quintis ao longo das duas décadas, o que é o mesmo que acompanhar o número de trabalhadores em uma mesma ocupação ao longo do tempo. Por exemplo: se crescem o número de empregadas domésticas (ocupação que situa no quintil inferior), e decai o número de "Gerentes de empresas de mineração" (quintil superior) entre T1 e T2, o saldo tenderá para um crescimento absoluto do primeiro quintil e uma queda do último.

A lógica, portanto, é de que o comportamento dos quintis irá espelhar as transformações da estrutura do mercado de trabalho, tanto do ponto de vista da qualidade dos empregos criados, como do saldo da geração de empregos no período. É importante que tenhamos isto em mente porque, às vezes, um forte crescimento dos quintis superiores (que pode dar a entender que ocorreu um salto qualitativo à primeira vista), pode vir acompanhado do crescimento também do número absoluto e relativo de inativos ou desocupados. Ou seja, cria-se uma gama de "bons empregos" no topo ao mesmo tempo em que um vasto contingente de trabalhadores não tem oportunidades de trabalho. Este foi, como vimos ao longo do capitulo 2, um dos dilemas enfrentados por parte dos países de economia avançada nos últimos 30 anos.

A figura abaixo (inspirada em Wright e Dwyer, 2003) ilustra quatro situações hipotéticas que poderiam ocorrer num determinado período (T1 a T2) em que o saldo de geração de empregos fosse de 1 milhão de postos. No primeiro, os quintis crescem de maneira equânime, sem que haja uma alteração profunda da estrutura do mercado de trabalho. O segundo e o terceiro são processos opostos: depreciação (crescimento dos quintis inferiores) e melhoria do emprego (crescimento dos quintis superiores), respectivamente. E o quarto é a polarização, com o crescimento concomitante dos quintis superiores e inferiores e uma queda dos quintis médios. Este último é o resultado observado por Wright e Dwyer (2003) e Autor et al (2003, 2006) para o contexto norte americano e por Goos e Maning (2009) para o Reino Unido e países de regimes de proteção social de cunho mais liberal na Europa Ocidental. 
Gráfico 6 - Quatro diferentes situações hipotéticas num cenário de criação de 1 milhão de empregos

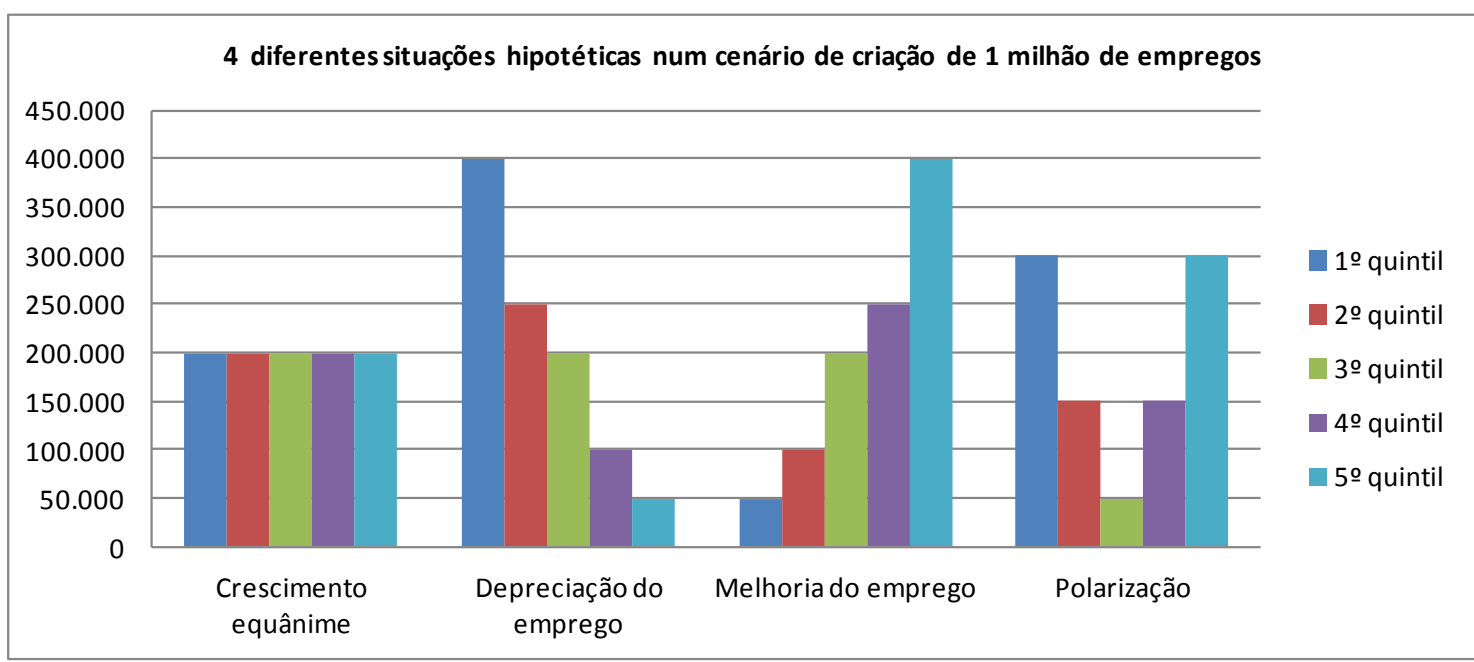

Adaptado de Wright e Dwyer (2003)

O procedimento que realizamos ${ }^{46}$ considerou o banco de dados do Censo Demográfico do IBGE, para a Região Metropolitana de São Paulo (apenas domicílios urbanos), para os anos de 1991, 2000 e 2010. Foram criadas ao todo 659 ocupações-setor, considerando todos os anos. As principais características do resultado final do procedimento se encontram nas tabelas 4 e 5 abaixo. Na primeira temos a distribuição dos quintis em cada um dos anos, com o número de pessoas e os percentuais, bem como a média da renda do trabalho. Na segunda, temos as três principais ocupações em cada um dos quintis e as respectivas rendas médias.

Tabela 4 - Distribuição dos quintis de ocupação e renda média: 1991, 2000 e 2010

\begin{tabular}{|c|ccc|ccc|ccc|}
\hline \multirow{2}{*}{ Quintil } & \multicolumn{4}{|c|}{1991} & \multicolumn{3}{c|}{2000} & \multicolumn{2}{c|}{2010} \\
\cline { 2 - 9 } & $\%$ & $\mathrm{~N}$ & Média da renda & $\%$ & $\mathrm{~N}$ & Média da renda & $\%$ & $\mathrm{~N}$ & Média da renda \\
\hline 10 Quintil & 22,0 & 1379969 & 899,5838 & 19,5 & 1485760 & 690,9150 & 18,3 & 1723259 & 750,23 \\
20 Quintil & 15,0 & 944805 & 1179,4046 & 18,3 & 1398601 & 1017,6648 & 14,1 & 1326881 & 902,47 \\
30 Quintil & 22,6 & 1417866 & 1337,7346 & 19,0 & 1448075 & 1235,7006 & 24,9 & 2341236 & 1366,66 \\
40 Quintil & 20,0 & 1257226 & 1728,0890 & 18,3 & 1398405 & 1762,6259 & 20,5 & 1928770 & 1743,75 \\
5o Quintil & 20,4 & 1282059 & 4091,4584 & 24,9 & 1903718 & 4291,7707 & 22,1 & 2072528 & 3961,42 \\
\hline
\end{tabular}

Fonte: Microdados dos Censos Demográficos (IBGE), 1991, 2000 e 2010. Elaboração própria.

\footnotetext{
46 Agradeço aqui a inestimável ajuda de Rogério Jerônimo Barbosa no tratamento dos dados e por considerações sobre as implicações substantivas da metodologia adotada.
} 
Tabela 5 - Principais ocupações dos quintis e renda média, 1991, 2000 e 2010

\begin{tabular}{|c|c|c|c|c|c|c|}
\hline \multirow{2}{*}{ Quintil } & \multicolumn{2}{|c|}{ Três maiores categorias no quintil (1991) } & \multicolumn{2}{|c|}{ Três maiores categorias no quintil (2000) } & \multicolumn{2}{|c|}{ Três maiores categorias no quintil (2010) } \\
\hline & Ocupação & Média da renda & Ocupação & Média da renda & Ocupação & Média da renda \\
\hline \multirow{3}{*}{ 10quintil } & Trabalhadores domésticos & 612,50 & Trabalhadores domésticos & 580,70 & Trabalhadores domésticos & 615,75 \\
\hline & $\begin{array}{c}\text { Trab braçais s/ qualificação da } \\
\text { indústria }\end{array}$ & 996,14 & $\begin{array}{l}\text { Operadores de máquinas na } \\
\text { indústria textil e de calçados }\end{array}$ & 832,13 & $\begin{array}{l}\text { Trabalhadores de limpeza do } \\
\text { setor de serviços }\end{array}$ & 659,15 \\
\hline & $\begin{array}{l}\text { Repositores de mercadorias no } \\
\text { setor de serviços }\end{array}$ & 1375,23 & $\begin{array}{c}\text { Trabalhadores elementares da } \\
\text { industria }\end{array}$ & 715,94 & $\begin{array}{l}\text { Operadores de máquinas na } \\
\text { indústria textil e de calçados }\end{array}$ & 754,03 \\
\hline \multirow{3}{*}{20 quintil } & $\begin{array}{c}\text { Pedereiros e outros } \\
\text { trabalhadores da Construção } \\
\text { Civil }\end{array}$ & 1154,52 & $\begin{array}{c}\text { Pedereiros e outros } \\
\text { trabalhadores da Construção } \\
\text { Civil }\end{array}$ & 1011,83 & $\begin{array}{c}\text { Pedereiros e outros } \\
\text { trabalhadores da Construção } \\
\text { Civil }\end{array}$ & 968,82 \\
\hline & $\begin{array}{l}\text { Trabalhadores do comércio } \\
\text { ambulante em geral }\end{array}$ & 1480,11 & $\begin{array}{l}\text { Trabalhadores do comércio } \\
\text { a mbulante em geral }\end{array}$ & 1192,89 & $\begin{array}{c}\text { Operadores de telemarketing e } \\
\text { serviços de informaçoes em } \\
\text { geral }\end{array}$ & 757,27 \\
\hline & $\begin{array}{l}\text { Garçons, cozinheiros, } \\
\text { atendentes do setor de } \\
\text { allimetação }\end{array}$ & 116,91 & $\begin{array}{c}\text { Garçons, cozinheiros, } \\
\text { atendentes do setor de } \\
\text { allimetação }\end{array}$ & 847,66 & $\begin{array}{c}\text { Garçons, cozinheiros, } \\
\text { atendentes do setor de } \\
\text { allimetação }\end{array}$ & 887,04 \\
\hline \multirow{3}{*}{ 3o quintil } & $\begin{array}{l}\text { Vendedores e banconistas do } \\
\text { comercio }\end{array}$ & 1381,16 & $\begin{array}{l}\text { Vendedores e banconistas do } \\
\text { comercio }\end{array}$ & 1187,22 & $\begin{array}{l}\text { Vendedores e banconistas do } \\
\text { comercio }\end{array}$ & 1368,20 \\
\hline & $\begin{array}{c}\text { Escriturários em geral do setor } \\
\text { de serviços }\end{array}$ & 1222,30 & $\begin{array}{c}\text { Escriturários em geral do setor } \\
\text { de serviços }\end{array}$ & 1258,53 & $\begin{array}{l}\text { Ocupações não especificadas no } \\
\text { setor de serviços }\end{array}$ & 2081,17 \\
\hline & $\begin{array}{l}\text { Operadores de maquina da } \\
\text { industria }\end{array}$ & 1257,94 & Vigias e seguranças & 1155,88 & $\begin{array}{c}\text { Escriturários em geral do setor } \\
\text { de serviços }\end{array}$ & 1655,90 \\
\hline \multirow{3}{*}{40 quintil } & $\begin{array}{l}\text { Motoristas e condutores de } \\
\text { veículos }\end{array}$ & 1775,83 & $\begin{array}{l}\text { Motoristas e condutores de } \\
\text { veículos }\end{array}$ & 1917,63 & $\begin{array}{l}\text { Motoristas e condutores de } \\
\text { veículos }\end{array}$ & 1372,91 \\
\hline & $\begin{array}{c}\text { Datilografos e operadores de } \\
\text { xerox }\end{array}$ & 1565,94 & $\begin{array}{l}\text { Professores do Ensino } \\
\text { Fundamental e Médio }\end{array}$ & 1702,96 & $\begin{array}{l}\text { Professores do Ensino } \\
\text { Fundamental e Médio }\end{array}$ & 1852,92 \\
\hline & $\begin{array}{l}\text { Polidores e ferramenteiros da } \\
\text { indústria }\end{array}$ & 1762,45 & $\begin{array}{l}\text { Polidores e ferramenteiros da } \\
\text { indústria }\end{array}$ & 1489,45 & \begin{tabular}{|c|} 
Mecânicos e reparadores de \\
veiculos e equipamentos eletro- \\
eletrônicos
\end{tabular} & 1309,14 \\
\hline \multirow{3}{*}{50 quintil } & $\begin{array}{l}\text { Gerentes e supervisores de } \\
\text { estabelecimentos comerciais }\end{array}$ & 4750,00 & $\begin{array}{c}\text { Chefes e engaregados de } \\
\text { sessoes administrativas dos } \\
\text { setor de serviços }\end{array}$ & 4143,10 & $\begin{array}{l}\text { Gerentes e supervisores de } \\
\text { estabelecimentos comerciais }\end{array}$ & 4819,04 \\
\hline & $\begin{array}{l}\text { Chefes e engaregados de } \\
\text { sessoes administrativas dos } \\
\text { serviços }\end{array}$ & 2564,44 & $\begin{array}{l}\text { Gerentes e supervisores de } \\
\text { estabelecimentos comerciais }\end{array}$ & 4966,07 & $\begin{array}{l}\text { Analistas financeiros e de } \\
\text { gestão; contadores }\end{array}$ & 3619,81 \\
\hline & $\begin{array}{c}\text { Chefes e engaregados de } \\
\text { sessoes administrativas da } \\
\text { industria }\end{array}$ & 2631,71 & $\begin{array}{l}\text { Corretores de seguros; tecnicos e } \\
\text { analistas de serviços bancarios }\end{array}$ & 2889,64 & $\begin{array}{l}\text { Corretores de seguros; tecnicos e } \\
\text { analistas de serviços bancarios }\end{array}$ & 2669,77 \\
\hline
\end{tabular}

Fonte: Microdados dos Censos Demográficos (IBGE), 1991, 2000 e 2010. Elaboração própria. 
É interessante notar algumas mudanças e continuidades que perpassam a composição dos quintis. No primeiro, as três principais ocupações em 1991 e 2010 são compostas por trabalhadores domésticos, uma ocupação do setor de serviços e uma da indústria. Não obstante, a ocupação de serviços em 1991 é a de "Repositores de Mercadoria", que se encontra majoritariamente no subsetor de "Comércio e distribuição". Já em 2010, a ocupação é a de "Trabalhadores da limpeza", refletindo a arrancada do subsetor de "Serviços prestados a empresas". Por outro lado, é interessante o fato de que não há nenhuma ocupação dos serviços em 2000, justamente quando o setor mais havia crescido em termos de composição do volume total de empregos e, sugerindo em primeira instância, que houve um crescimento desproporcional desse setor na estrutura ocupacional.

No segundo quintil, um novo movimento também tem lugar e ilustra a transição da estrutura ocupacional na RMSP entre 1991 e 2010. A composição seria a mesma em todos os anos, não fosse o fato de que os "Trabalhadores ambulantes" foram substituídos pelos “Operadores de Telemarking”. Esta não é uma mudança desprezível e, em especial, nos mostra a relevância de se expandir a análise meramente focada na renda para uma que considere a dinâmica das ocupações. Ao espelhar um salto qualitativo no que concerne à formalização, não deixa de ser trivial o fato de que os trabalhadores na base da estrutura deixem de ser majoritariamente os "ambulantes" para se tornarem "Operadores de Telemarketing", seja do ponto de vista da ordem social que se estabelece, seja do ponto de vista da inscrição que nele se faz.

O comportamento do terceiro quintil, por sua vez, ilustra a queda do emprego industrial que teve lugar a partir dos anos 1990. Os “Operadores de máquina da indústria" são a terceira principal ocupação em 1991, mas desaparecem nos anos seguintes. Não deixa de chamar atenção, entretanto, o crescimento dos salários nesse quintil no ano de 2010, o que voltará a se evidenciar nos resultados que apresentaremos a seguir.

No quarto quintil, a queda do emprego industrial novamente se destaca: em 2010 nenhuma das ocupações provem deste setor. Notamos, ainda, a presença dos "professores" a partir dos 2000, novamente como uma ilustração da expansão do setor de "educação", como já tratamos anteriormente. 
Por fim, no quintil superior, volta a se expressar a forte presença dos "Serviços prestados a empresas", a sugerir o relevo da reestruturação micro-organizacional: em 1991, todos são "chefes ou gerentes"; em 2000, já temos a presença dos "corretores"; e em 2010, duas das principais ocupações são dessa última natureza. Vemos, assim, uma espécie de transição gradual do "mundo gerencial da empresa" para o "mundo dos consultores" (Donadonne, 2009).

\subsection{Evolução da estrutura ocupacional nos 1990 e nos 2000}

As duas décadas em muito se diferenciam quanto ao volume de postos de trabalho criados (1,3 milhão nos 1990 contra 1,8 milhão nos 2000). E, embora tenhamos ressaltado as mudanças no que se refere à estrutura salarial e escolaridade, poucas considerações tecemos sobre o desenvolvimento da estrutura ocupacional.

Os dois gráficos a seguir (7 e 8) apresentam a evolução da geração de empregos da RMSP segundo o saldo de indivíduos nos quintis de ocupação ${ }^{47}$ nas duas décadas e permitem avaliar parcialmente a solidez das hipóteses. Como se pode notar, o primeiro ponto da nossa hipótese mais geral, que tratava apenas da diferença no padrão de evolução da estrutura ocupacional nas duas décadas, pode ser confirmado.

\footnotetext{
${ }^{47}$ Realizamos um exercício contrafactual que apresenta o saldo dos quintis caso estes tivessem sido ordenados não pelo total de indivíduos, mas sim pelo critério ocupacional, ou seja, a partir do ordenamento das ocupações. Os resultados desse exercício confirmam a mesma tendência apresentada aqui, corroborando os resultados originais, e podem ser consultados no Anexo Metodológico da presente dissertação. Agradeço ao Professor Adalberto Cardoso (IESP/UERJ) a sugestão de se realizar este exercício alternativo.
} 
Gráfico 7 - Evolução da estrutura ocupacional: saldo dos quintis de ocupação RMSP, 1991-2000

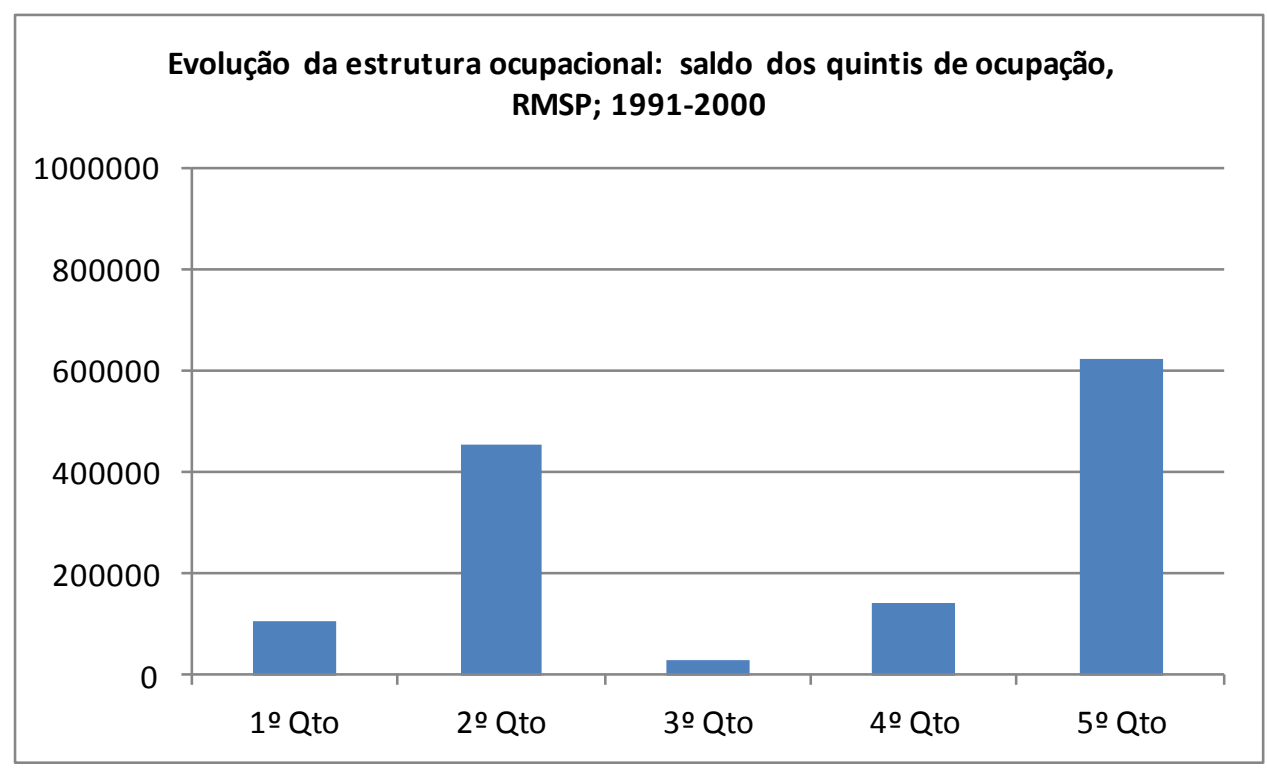

Fonte: Microdados dos Censos Demográficos (IBGE), 1991, 2000 e 2010. Elaboração própria.

Gráfico 8 - Evolução da estrutura ocupacional: saldo dos quintis de ocupação, RMSP; 2000-2010

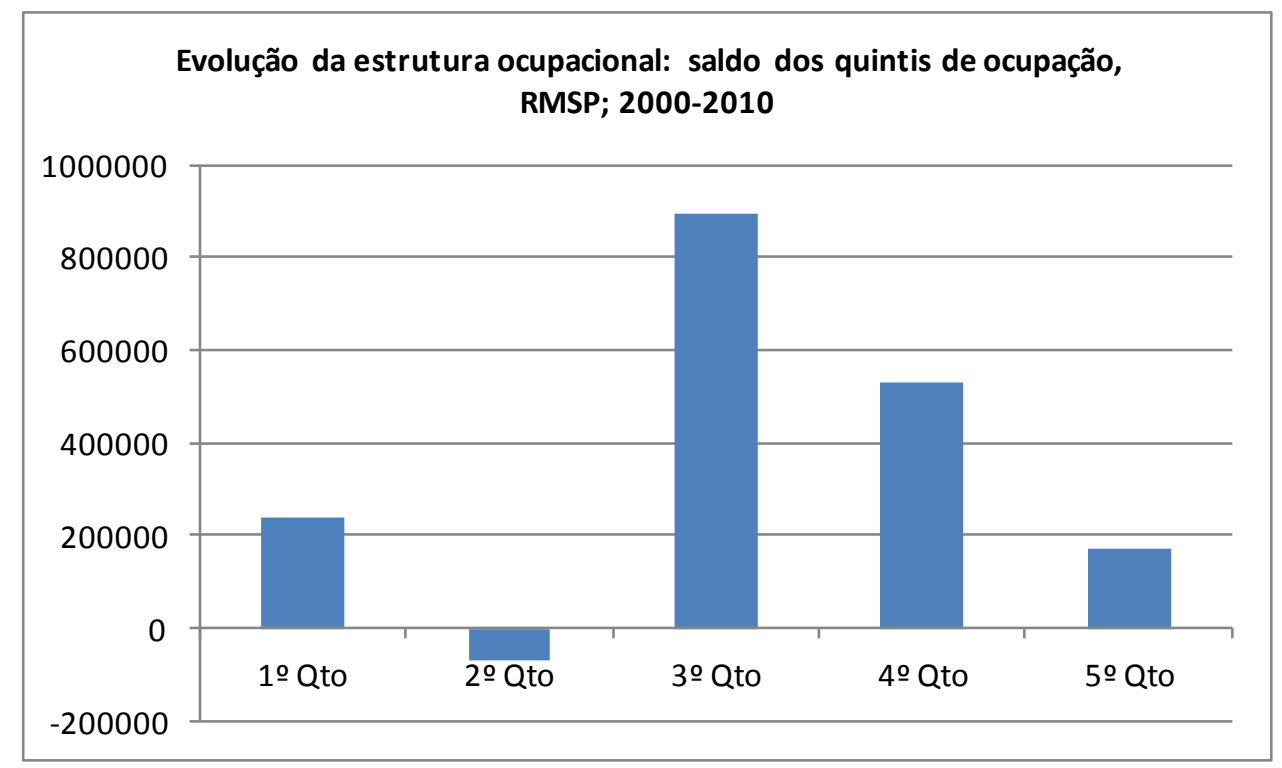

Fonte: Microdados dos Censos Demográficos (IBGE), 1991, 2000 e 2010. Elaboração própria.

Observemos inicialmente o que se passou na década de 1990. Tal como mostra o primeiro dos gráficos relativos à evolução da estrutura ocupacional, é possível reconhecer um movimento de polarização, embora com padrão algo distinto daquele que poderíamos denominar como modelo "clássico", e que apresentamos anteriormente 
ao retratar os EUA e países da Europa Continental. A polarização, na RMSP, se dá em função do crescimento desproporcional do segundo e do quinto quintis, no qual destacamos anteriormente as ocupações mais presentes ("Trabalhadores da construção civil", "Ambulantes" e "Garçons e outras ocupações do setor de alimentação" no segundo quintil; e "Chefes nos serviços", "Gerentes no comércio" e "Corretores" no quinto quintil). Ou seja, esse achado reforça, do lado da estrutura ocupacional, o crescimento do setor de serviços e da sua heterogeneidade interna (como vimos com o crescimento da dispersão salarial), ao mesmo tempo em que a redução do assalariamento formal, com o crescimento dos ambulantes. Vejamos com mais detalhes.

Sugerimos na Hipótese 2.0 que essa tendência à polarização, que se confirmou, resultaria de três fatores determinantes, a saber: i) as mudanças na demanda por trabalho (diminuição da demanda relativa por trabalho menos qualificado na base e aumento da demanda pelos mais qualificados); a essas mudanças se associariam ii) a forte queda dos empregos industriais e o crescimento da heterogeneidade na geração de empregos ao interior do setor de serviços; iii) e a flexibilização das relações de trabalho que teve lugar ao longo da década.

O primeiro determinante encontrava respaldo em fatos que observamos em seções anteriores: por um lado, o aumento da taxa de desocupação entre as pessoas com ensino superior ao longo dos anos 1990, que foi inferior ao aumento das taxas de desocupação como um todo; por outro lado, o forte crescimento dos salários desse estrato educacional. Os Gráfico 9, 10 e 11 permitem corroborar este ponto.

Nos dois primeiros (Gráfico 9 e Gráfico 10) temos a distribuição dos estratos educacionais ${ }^{48}$ pelos quintis de ocupação em cada um dos anos, de modo que podemos ver em quais quintis se situam os trabalhadores segundo seu nível educacional ${ }^{49}$. No terceiro (Gráfico 11) temos o saldo dos quintis segundo os estratos educacionais ${ }^{50}$, mas aproveitamos para incluir um "novo quintil": o do saldo das pessoas "desocupadas".

\footnotetext{
48 Tratamos os estratos educacionais da seguinte forma: Fundamental Incompleto (F.I.); Fundamental Completo (F.C.); Médio Completo (M.C.); Superior Completo (S.C.).

49 Ao analisarmos a distribuição dos quintis no interior dos estratos educacionais, controlamos os efeitos de variação absoluta na composição da oferta.

${ }^{50}$ Este segundo gráfico é mais sensível às variações absolutas na oferta mas, lido em conjunto com os dois primeiros, corrobora a tendência observada
} 
Assim podemos observar também quais os estratos educacionais foram mais ou menos prejudicados com a elevação das taxas de desemprego.

Começando pelos dois primeiros, podemos ver que em 1991 67,0\% das pessoas no quintil mais elevado tinham ensino superior. Em 2000, esse percentual é de 74,3\%, ao mesmo tempo em que em todos os outros quintis observamos declínio das pessoas com ensino superior.

Gráfico 9 - Distribuição dos estratos educacionais, segundo os quintis de ocupação, RMSP; 1991

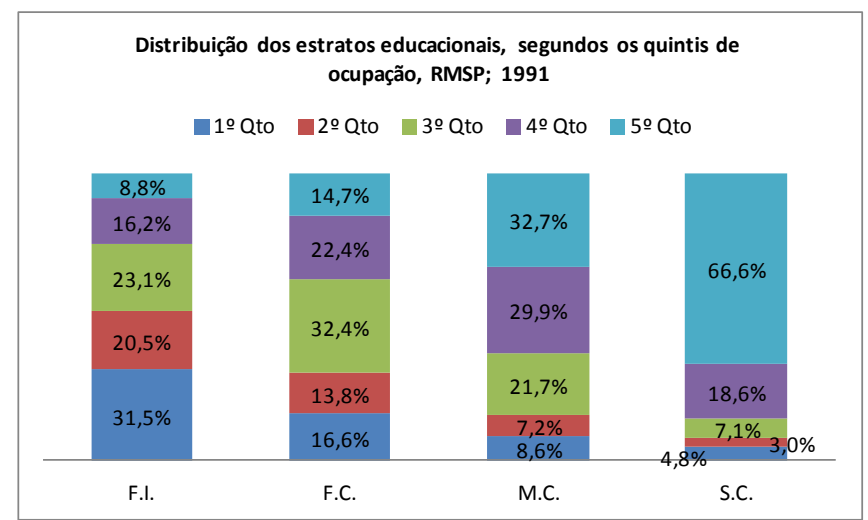

Fonte: Microdados dos Censos Demográficos (IBGE), 1991, 2000 e 2010. Elaboração própria.

Gráfico 10 - Distribuição dos estratos educacionais, segundo os quintis de ocupação, RMSP; 2000

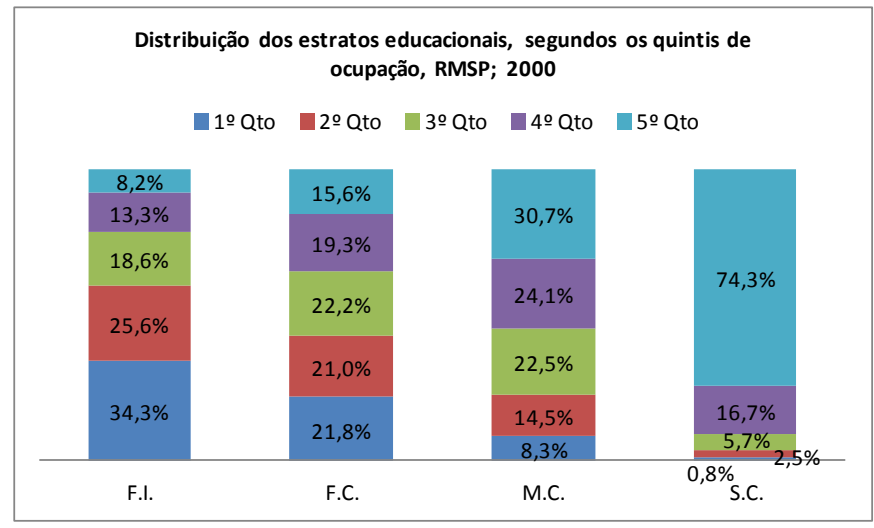

Fonte: Microdados dos Censos Demográficos (IBGE), 1991, 2000 e 2010. Elaboração própria.

O Gráfico 11 a seguir reforça este argumento. Do saldo total dos empregos nos quintis, apenas no quintil mais elevado observamos um forte crescimento das pessoas com ensino superior. Embora esse gráfico seja sensível à variação absoluta na oferta - o 
número de pessoas com ensino superior cresceu significativamente no período - é notável que em nenhum dos outros quintis (à exceção marginal do quarto quintil) observa-se um saldo positivo de pessoas com Ensino Superior. Isto nos permite dizer que, das pessoas com esse nível educacional que se beneficiaram da geração de postos de trabalho ao longo dos anos 1990, a esmagadora maioria teve como destino as melhores ocupações.

Gráfico 11 - Saldo de ocupados e desocupados, segundo quintis de ocupação e controlando pela escolaridade, RMSP; 1991-2000

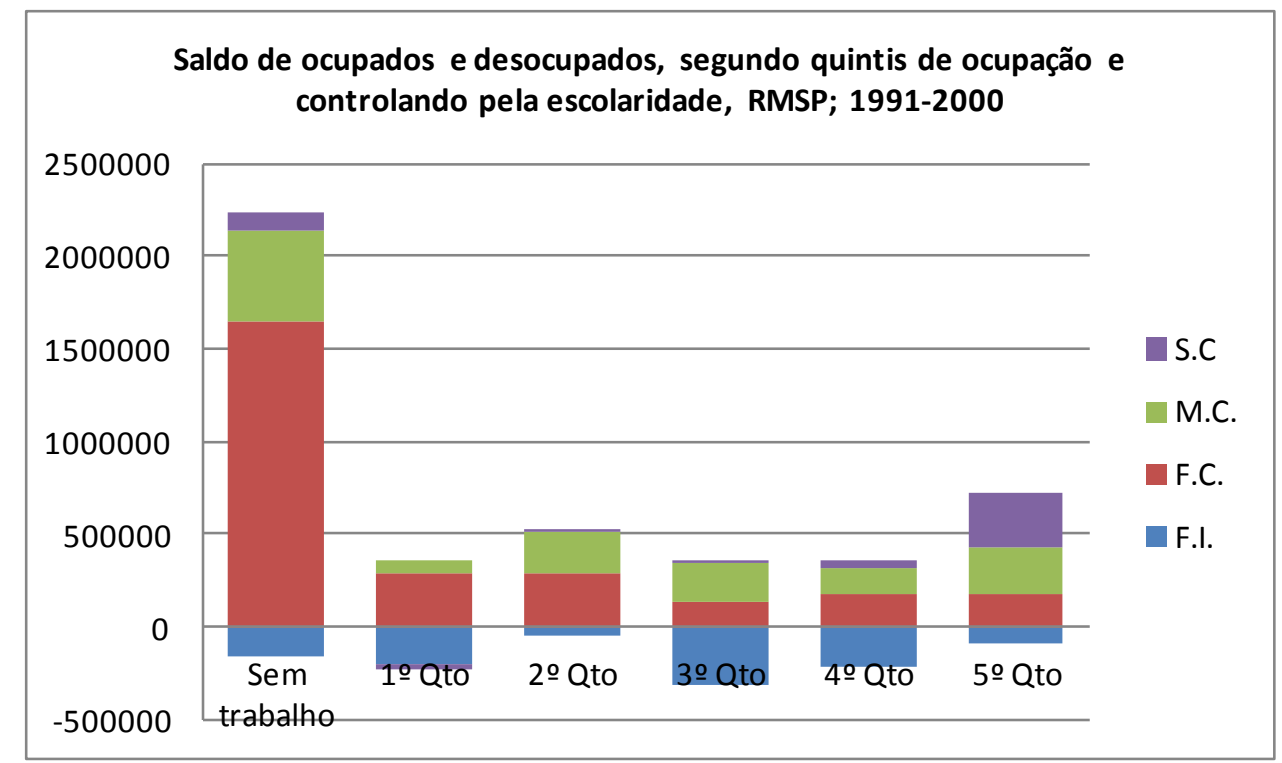

Fonte: Microdados dos Censos Demográficos (IBGE), 1991, 2000 e 2010. Elaboração própria.

A questão aqui não é tanto, ao modo de uma certa variante da literatura internacional antes apresentada, saber se houve um incremento tecnológico que demandou maior presença, no quintil superior, dos trabalhadores mais qualificados, evidenciando, assim, maior necessidade por capital humano. À diferença disso, poder-se-ia aventar que, no nosso caso, tenhamos tido um elevado efeito de inflação de diplomas. Independentemente da sua origem e dos mecanismos de absorção das credenciais educacionais, importa, para fins da nossa hipótese, sublinhar o incremento da demanda por pessoas com ensino superior no topo da hierarquia, responsável por fazer inflar as ocupações ali situadas e atuando como mecanismo estrutural de polarização ocupacional. 
Quando observamos o que se passa na porção inferior da distribuição, notamos que, do saldo de desocupados, mais de 3/5 tinha até o Ensino Fundamental Completo, bem como um saldo negativo das pessoas com Fundamental Incompleto em todos os quintis. Certamente a variação absoluta na composição educacional da oferta teve um forte peso nesse processo. Comparada com 1991, em 2000 a PEA tinha 430.000 pessoas a menos com Fundamental Incompleto, 1,6 milhão a mais com Fundamental completo e cerca de 1,2 milhão a mais com Médio completo, o que permitiria explicar o movimento da década: o saldo negativo para aqueles com fundamental incompleto refletiria a queda no número absoluto de pessoas pertencentes a este estrato educacional. Mas isso não é fato, haja visto que o saldo negativo das pessoas com Fundamental Incompleto é superior à variação negativa na PEA; ou seja, não podemos atribuir o saldo negativo na estrutura ocupacional apenas à variação absoluta dos efetivos.

Isso nos autoriza a sugerir que houve uma inflexão no tipo de demanda de trabalho, que se fez em detrimento dos indivíduos menos qualificados, o que se reforça se observarmos os dois primeiros gráficos. Das pessoas com ensino fundamental completo em 1991, 32,0\% e 21,0\% se encontravam nos dois quintis inferiores. Nos 2000, esse percentual sobe para $34,0 \%$ e $26,0 \%$, respectivamente. Ou seja, as mudanças na demanda por trabalho mais qualificado contribuíram significativamente para o processo de polarização ocupacional que teve lugar ao longo dos anos 1990.

E o que podemos dizer acerca do segundo fator determinante da polarização, a saber, a mudança na estrutura setorial do emprego, expressa na recomposição da ocupação segundo os setores de atividade econômica?

Os dados apresentados no Gráfico 12 secundam uma primeira evidência em favor do que havíamos aventado, a saber, que a queda do emprego industrial contribuiu para a polarização da estrutura ocupacional. Chama atenção, nesse caso, o elevado saldo negativo da indústria no quintil intermediário, equivalente a quase o mesmo montante da geração de empregos nos serviços, de modo que o resultado final é praticamente nulo, resultando em uma estagnação do miolo da estrutura ocupacional. Por outro lado, o primeiro quintil foi predominantemente preenchido pelas atividades domésticas, que compensaram a queda do emprego industrial ali situado. 
Gráfico 12 - Saldo de ocupados, segundo quintis de ocupação e controlando por setores de atividades econômicas, RMSP; 1991-2000

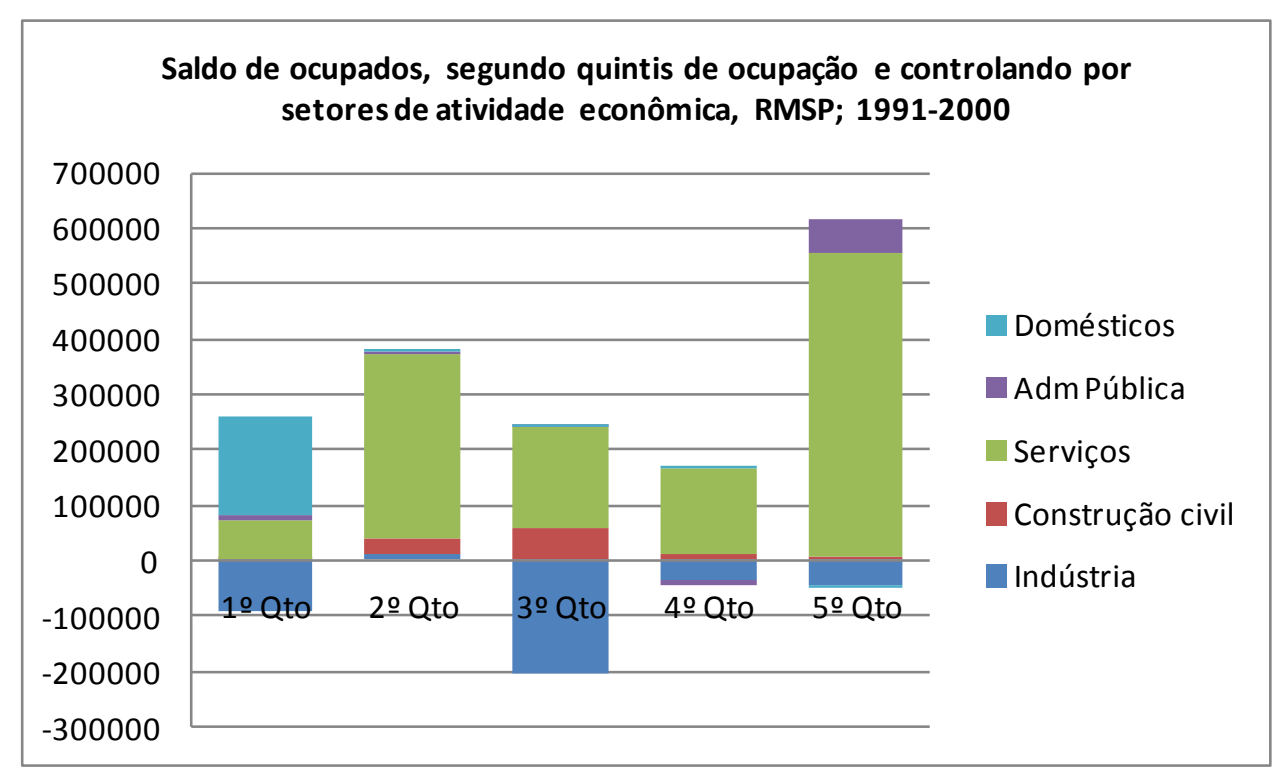

Fonte: Microdados dos Censos Demográficos (IBGE), 1991, 2000 e 2010. Elaboração própria.

Além do efeito relacionado à queda do emprego industrial, havíamos sugerido que o processo de polarização também poderia estar associado à crescente heterogeneidade da geração de empregos no interior do setor de serviços e ao crescimento da variação salarial interna a cada um desses subsetores.

Observando o Gráfico 13 abaixo, vê-se que este argumento fica ali parcialmente confirmado. Se tomarmos os dois quintis que sustentaram o movimento de polarização ocupacional (o segundo e o quinto), vemos que, no primeiro, a grande maioria dos empregos gerados se deu no subsetor de "Hotelaria e Restaurante". Já no quinto, há uma maior diferenciação, embora se destaquem os subsetores de "Comércio e Distribuição" e de "Serviços Prestados a Empresas". Este ultimo, em especial, parece ter jogado o papel de principal determinante, pois, como havíamos observado, ele experimentou, ao longo dos anos 1990, um forte crescimento da renda relativa acompanhada da dispersão salarial. 
Gráfico 13 - Saldo de ocupados, segundo quintis de ocupação e controlando por subsetores do setor de serviços, RMSP; 1991-2000

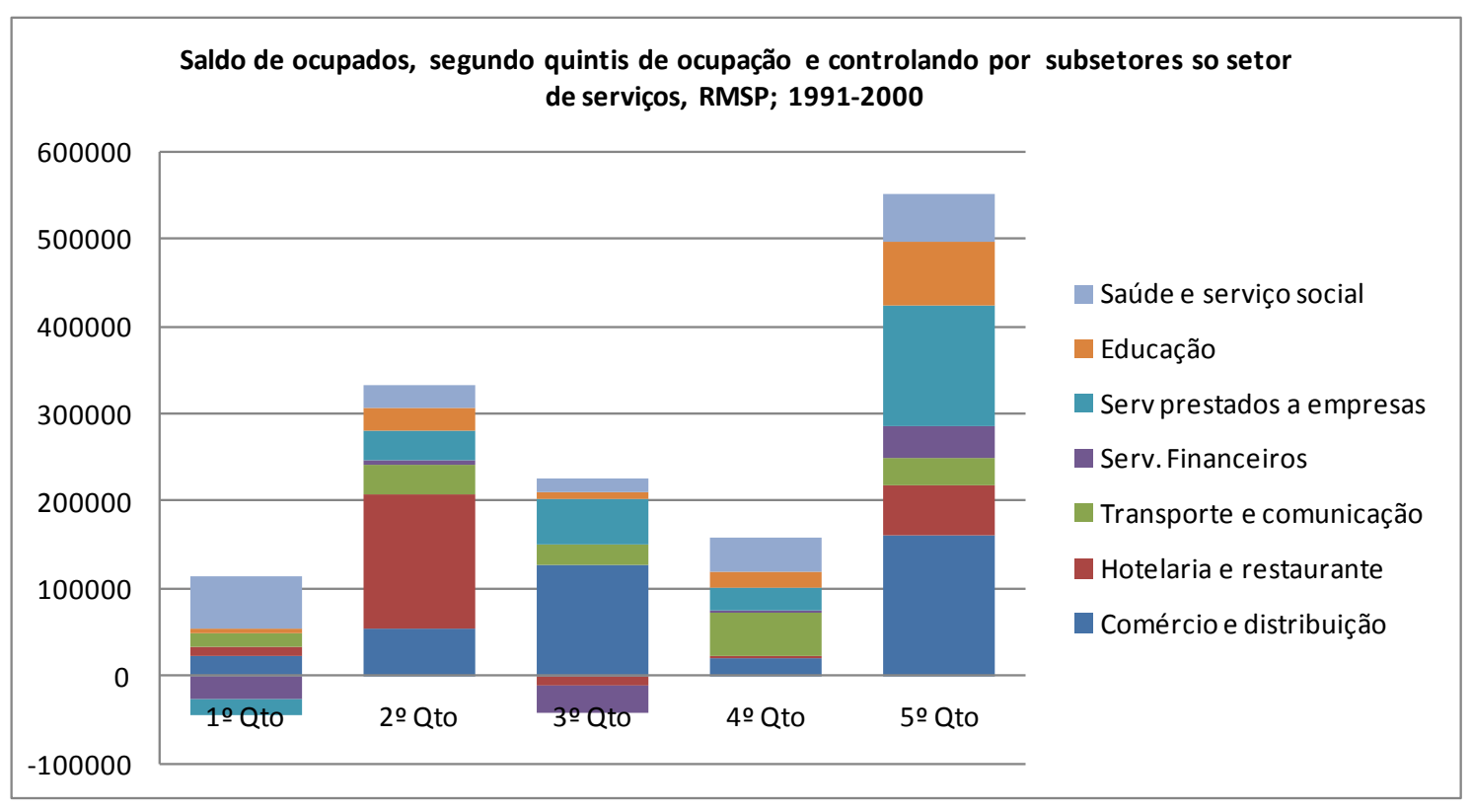

Fonte: Microdados dos Censos Demográficos (IBGE), 1991, 2000 e 2010. Elaboração própria.

Por fim, um último determinante para o processo de polarização ocupacional aventado ao formularmos a hipótese $2.0 \mathrm{diz}$ respeito à flexibilização das relações de trabalho. Como antecipado, não temos, a esse respeito, forma de traçar empiricamente qualquer relação mais sustentada de causalidade; podemos apenas sugerir que esse movimento de flexibilização atuou como pano de fundo institucional do processo de polarização. Tal sugestão entretanto, encontra forte respaldo na literatura, tal como apresentado em maior detalhe ao longo do primeiro capitulo.

Posto isso, parece ser possível concluir que ficou documentada a ocorrência de um processo de polarização da estrutura ocupacional, que teve lugar ao longo dos anos 1990; bem assim, os dados apresentados sustentaram a hipótese formulada a respeito dos mecanismos estruturais que lhe condicionaram. Se, como observamos em paginas anteriores, não podemos dizer que, raiz dessa transformação, esteja um processo de mudança tecnológica de tipo skill-biased, ao modo como a literatura chamou atenção para alguns dos países desenvolvidos, parece apropriado concluir que, entre nós, o processo de polarização da estrutura ocupacional encontrou nas transformações da demanda por trabalho (tanto do ponto de vista da absorção de qualificação, como da 
mudança da atividade produtiva) um de seus principais motivadores. E, embora não tenhamos sustentado com dados a ideia de que a flexibilização das relações de trabalho, seguida da reestruturação micro-organizacional ao longo da década, também teria contribuído para esse processo, podemos respaldá-la com base na literatura que revisamos.

Resta saber em que medida tais processos se articularam à evolução da pobreza no período e como vinculá-la à proteção social na base da pirâmide, permitindo traçar considerações sobre este ponto que diz respeito à nossa Hipótese 2.1. Antes, entretanto, trataremos da evolução da estrutura ocupacional nos 2000, para posteriormente nos determos sobre as implicações que trazem para pobreza nas duas décadas que estamos analisando.

Vimos no Gráfico 7 acima que a evolução da estrutura ocupacional entre 2000 e 2010 se portou diferentemente do que esperávamos tal como construímos a hipótese $3.0^{51}$. Afinal, supúnhamos que o crescimento maciço dos estratos de até 2 salários mínimos na década se refletiria mais evidentemente na base da estrutura. Isto chegou a ocorrer em parte, com o crescimento não desprezível do primeiro quintil, mas foram os terceiros e quarto quintis aqueles que de longe mais se destacaram. Por outro lado, surpreende de certa forma o fato de o segundo quintil ter apresentado saldo negativo. Cabe agora, portanto, explorar os condicionantes desse comportamento.

Em primeiro lugar, havíamos colocado que a receptividade da demanda por trabalho aos menos qualificados, à diferença da década de 1990, atuaria como um vetor no sentido de proporcionar o crescimento dos quintis inferiores. Vejamos, então, como os diferentes quintiis de ocupação se distribuem pelos estratos educacionais, repetindo o mesmo exercício que fizemos para a década de 1990 (Gráfico 14,

Gráfico 15 e Gráfico 16), mas agora com os dados de $2000^{52}$ e 2010.

\footnotetext{
${ }^{51}$ Hipótese 3.0: Os anos 2000 são marcados por uma tendência de crescimento da base da estrutura ocupacional, de virtude de: i) mudança na natureza da demanda por qualificação (cresce a demanda pelos menos qualificados e cai a demanda pelos mais qualificados), a qual está associada: ii) ao forte crescimento dos subsetores de serviços onde são menores os salários (em especial comércio e distribuição $)^{51}$; iii) à continuidade da fluidez do mercado em termos de flexibilidade das relações de trabalho.

${ }^{52}$ O Gráfico para o ano de 2000 é o mesmo apresentado anteriormente, mas o repetimos aqui para facilitar a visualização e sua articulação com o desenvolvimento do argumento.
} 
Gráfico 14 - Distribuição dos estratos educacionais, segundos os quintis de ocupação, RMSP; 2000

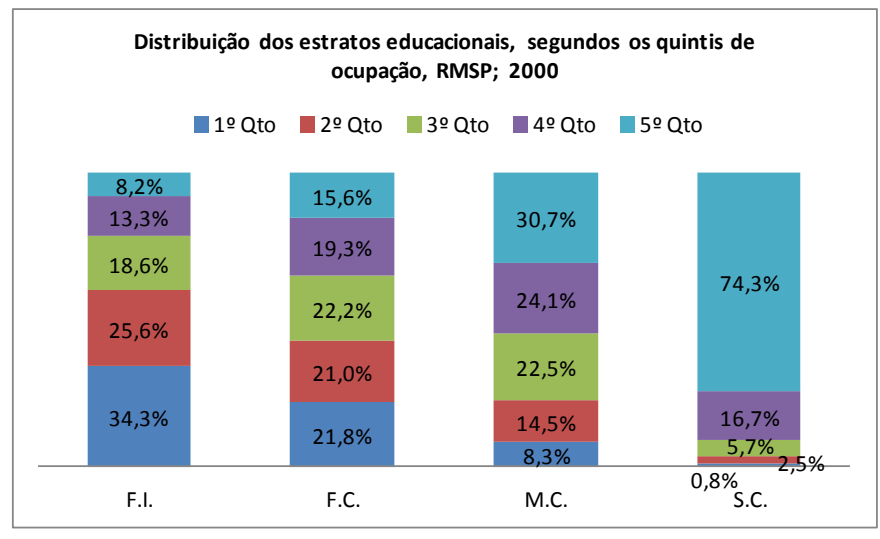

Fonte: Microdados dos Censos Demográficos (IBGE), 1991, 2000 e 2010. Elaboração própria.

Gráfico 15 - Distribuição dos estratos educacionais, segundos quintis de ocupação, RMSP; 2010

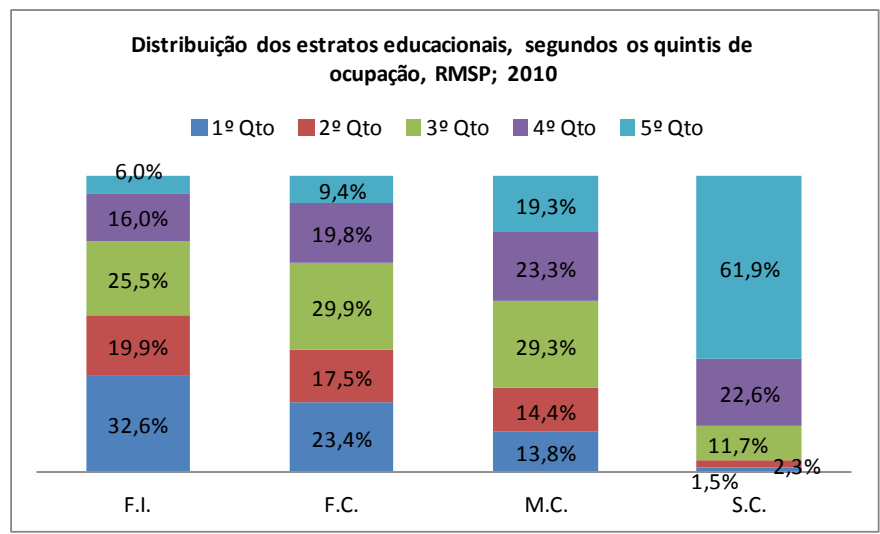

Fonte: Microdados dos Censos Demográficos (IBGE), 1991, 2000 e 2010. Elaboração própria. 
Gráfico 16 - Saldo de ocupados e desocupados, segundo quintis de ocupação e controlando pela escolaridade, RMSO; 2000-2010

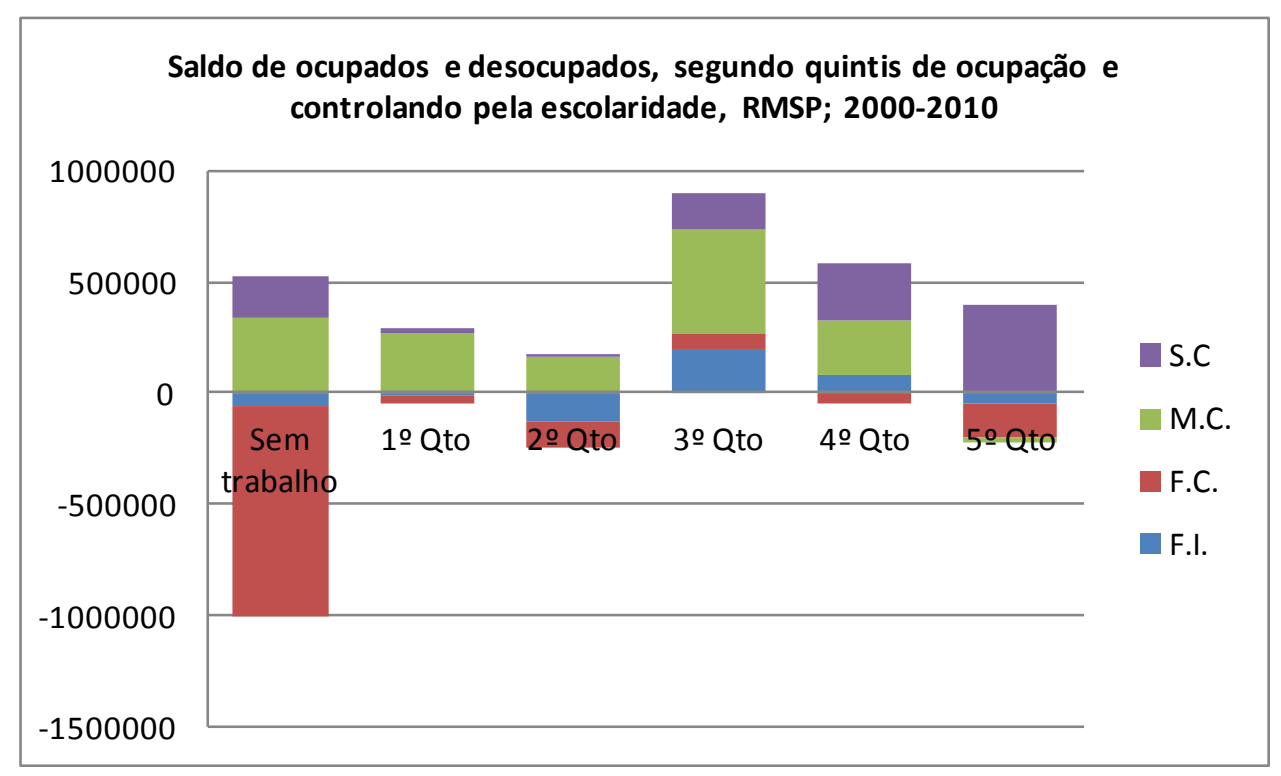

Fonte: Microdados dos Censos Demográficos (IBGE), 1991, 2000 e 2010. Elaboração própria.

Os resultados mostram que houve uma maior diversificação de absorção da educação em todos os quintis, e isso traz inúmeras implicações. A primeira delas é que, embora já tivéssemos observado a queda dos retornos do diploma de ensino superior, é interessante notar que essa queda não diz respeito apenas ao salário, mas também ao tipo de ocupação que está sendo preenchida por pessoas desse estrato educacional. O percentual de pessoas no quinto quintil com ensino superior cai de 74,3\% em 2000 para $61,9 \%$ em 2010, um valor mais baixo que no ano de 1991. Como é bem possível verificar, eles se dirigem predominantemente para o quintil imediatamente inferior, o que sugere um efeito de desvalorização de credenciais que estaria perpassando as ocupações do quarto quintil.

Por outro lado, aqueles com menor escolaridade parecem ter sido os principais beneficiados da transformação da estrutura ocupacional ocorrida nos anos 2000. Os que tinham apenas o Ensino Fundamental Incompleto ocupam menos os dois quintis inferiores e mais o terceiro e quarto quintis, conquanto mais naquele do que neste. Já aqueles com escolaridade intermediária (Fundamental Completo e Médio Completo) se dirigiram em boa medida ao terceiro quintil. Em especial para os que completaram o Ensino Médio, os dados mostram: i) uma menor proporção de trabalhadores do quintis 
superior nesse grupo, comparando 2010 com 2000 (os valores são de 19,3\% e 30,7\%, respectivamente); e ii) uma maior proporção em 2010 de trabalhadores do primeiro e do terceiro quintis, comparando com 2000 ( $1^{\circ}$ quintil: 8,3\% em 2000 e 13,8\% em 2010; $3^{\circ}$ quintil: $22,5 \%$ e $29,3 \%)$.

As pessoas com Ensino Médio Completo parecem ter sido os principais perdedores, em termos relativos, por efeito das mudanças na estrutura ocupacional ocorridas nesta década. Este fato, entretanto, encontra uma de suas razões no crescimento absoluto das pessoas com esse nível educacional. Em 2000, esse total era de 2.486.239, representando 25,9\% da PEA. Em 2010, esses valores passaram a ser 3.523.135 e $34,1 \%$, respectivamente. Ou seja, na medida em que cresceu consideravelmente o percentual de pessoas com Ensino Médio, elas passaram a ocupar, relativamente, mais postos inferiores do que ocupavam antes, tomando os lugares daqueles menos escolarizados. Mas se apenas isto explicasse o seu movimento, deveríamos observar mais pessoas ocupadas no quarto quintil dentre aqueles com Ensino Médio, e isto não aconteceu.

Acreditamos que não aconteceu justamente porque foi o terceiro quintil aquele que mais cresceu, e não o quarto. Dessa forma, o que parece estar havendo é um movimento de menor diferenciação da estrutura ocupacional para os níveis de escolaridade até o Ensino Médio Completo em especial. Tal movimento é decorrente do tipo de emprego que foi gerado na década de 2000, fortemente concentrado no quintil intermediário. Em outras palavras, a tendência observada parece depender mais da composição da demanda do que da oferta.

Isto nos leva a concluir que um dos pontos chave da nossa hipótese 3.0 não se confirma com a análise dos dados. Muito pelo contrário, foi justamente a própria transformação da estrutura ocupacional que modificou os parâmetros estruturais de inserção dos diferentes grupos educacionais, aproximando-os entre si, embora seja claro que as ocupações superiores (quinto quintil) ainda constituem um nicho das pessoas com Ensino Superior.

Resta avaliar, portanto, se podemos encontrar nos setores de atividade econômica uma das causas para esse processo. 
Quanto aos grandes setores, nada pode ser dito a respeito. Como mostra o primeiro Gráfico 17 abaixo, é nos serviços que a grande maioria das ocupações foi criada; e isso ocorreu em todos os quintis. Todavia, como havíamos suspeitado, há uma forte concentração de empregos gerados segundo os subsetores, como mostra o

Gráfico 18 subsequente.

Gráfico 17 - Evolução da estrutura educacional, segundo saldo dos quintis e grandes setores de atividades econômica, RMSP; 2000-2010

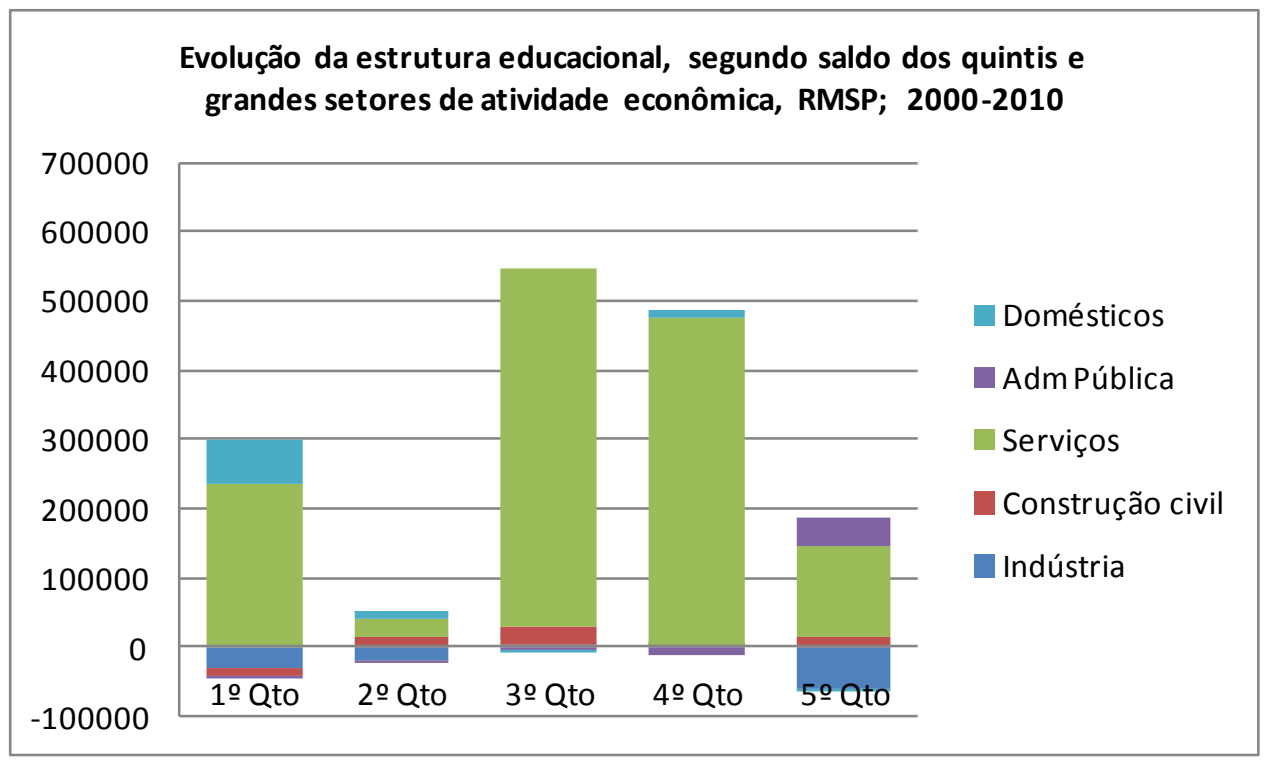

Fonte: Microdados dos Censos Demográficos (IBGE), 1991, 2000 e 2010. Elaboração própria. 
Gráfico 18 - Evolução da estrutura educacional, segundo saldo dos quintis (apenas subsetores dos serviços), RMSO; 2000-2010

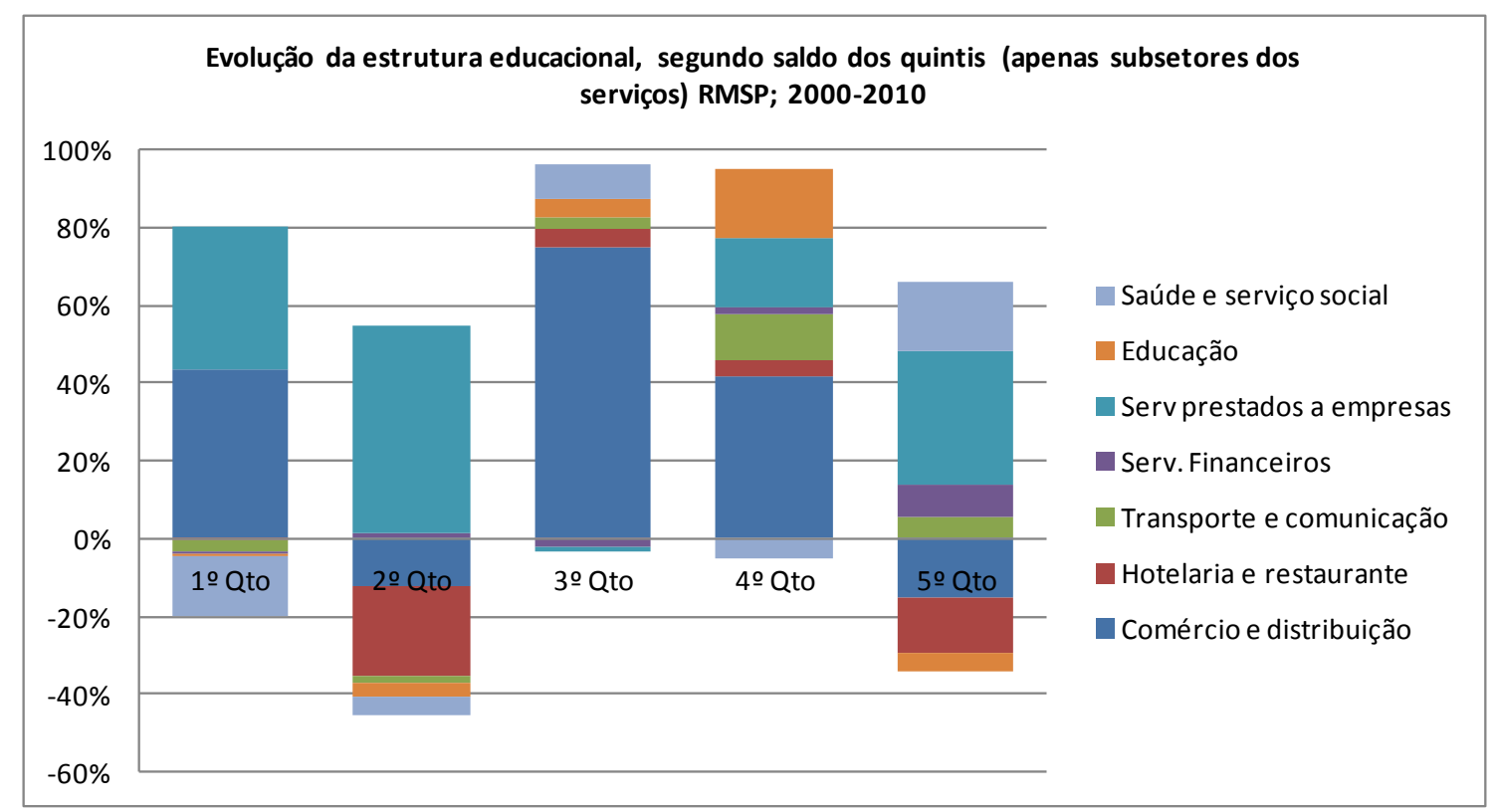

Fonte: Microdados dos Censos Demográficos (IBGE), 1991, 2000 e 2010. Elaboração própria.

O subsetor de Comércio e Distribuição é, de longe, aquele que mais gerou postos de trabalho ao longo dos anos 2000 , sendo responsável por quase $80,0 \%$ do crescimento do quintil intermediário e quase 50,0\% do quarto quintil, nos levando a crer que se tratou da principal alavanca do padrão que se estabeleceu no período. Seu movimento, entretanto, foi balanceado por uma diferenciação interna do subsetor de Serviços Prestados a Empresas. Na década de 2000, como havíamos observado, a maioria dos empregos nesse subsetor tinha sido criado no primeiro quintil, talvez como um primeiro movimento de terceirização da metrópole no período, concentrado nas atividades mais especializadas e com maiores salários. Na ultima década, esse movimento parece se expandir para outros tipos de atividade, gerando mais empregos nos dois quintis inferiores. É de se destacar, ainda, o saldo negativo do setor de "Hotelaria e Restaurante", o principal motor do segundo quintil na década de 1990, o que ajuda a explicar o saldo negativo deste quintil entre 2000 e 2010.

Novamente, não temos como avaliar empiricamente o "peso" da fluidez do mercado de trabalho, no que concerne à flexibilidade das relações de trabalho, nesse processo, sendo 
mais prudente nos apoiarmos no que a literatura já diagnosticou sobre o tema. Não obstante, optamos for realizar um breve exercício tomando a taxa de formalização como uma proxy da institucionalização do mercado. Mesmo sendo este um exercício pouco robusto empiricamente para o que se propõe a explicar, acreditamos que seja válido mostrar como a formalização se distribuiu no interior da estrutura ocupacional ao longo dos anos.

E, sobre isso, os gráficos a seguir (Gráfico 19 e Gráfico 20) são bastante ilustrativos. Para os anos 1990, os únicos quintis que apresentaram algum saldo positivo com ganhos de formalidade foram o segundo e o quinto, justamente aqueles que alavancaram o processo de polarização que teve lugar no período. Já na década de 2000, é também o quintil (o terceiro) que foi o principal mote do padrão de evolução da estrutura ocupacional aquele que apresentou algum saldo relevante de informalidade.

Gráfico 19 - Saldo de ocupados, segundo quintis de ocupação e controlando por formalização, RMSP; 1991-2000

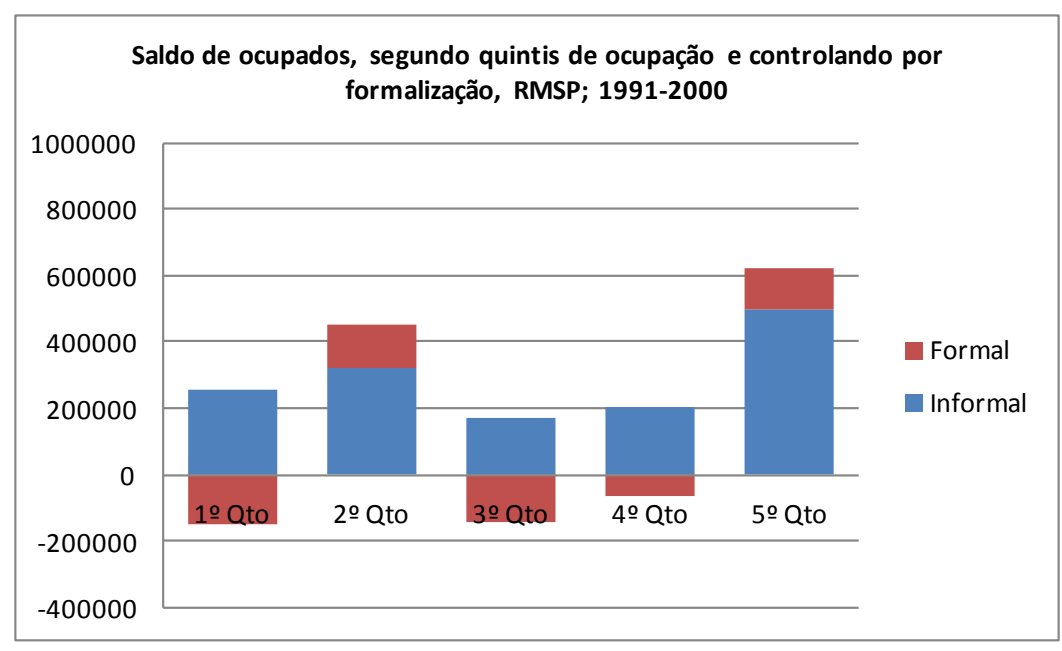

Fonte: Microdados dos Censos Demográficos (IBGE), 1991, 2000 e 2010. Elaboração própria. 
Gráfico 20 - Saldo de ocupados, segundo quintis de ocupação e controlando por formalização, RMSP; 2000-2010

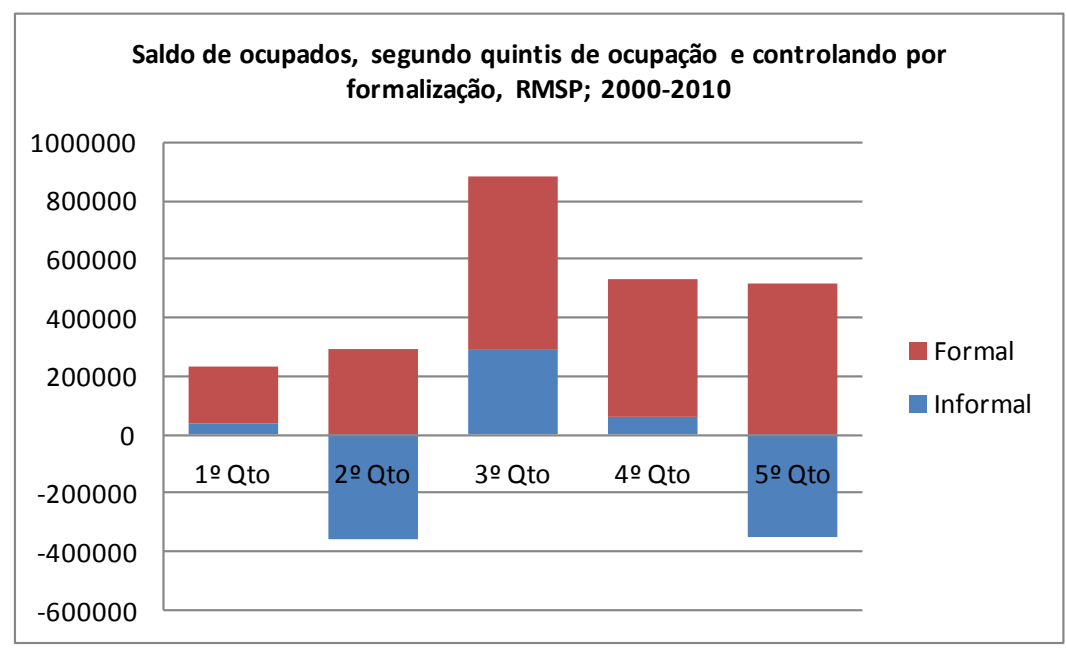

Fonte: Microdados dos Censos Demográficos (IBGE), 1991, 2000 e 2010. Elaboração própria.

Estes resultados não nos permitem indicar que o grau de formalização condicionou o padrão de evolução da estrutura ocupacional (ou vice-versa), mas sugerem algo interessante. Para os 1990, eles corroboram a hipótese de que a polarização esteve associada à flexibilização das relações de trabalho, na medida em que o saldo dos empregos formais é positivo apenas nos setores polares (segundo e quinto).

Para os 2000, por outro lado, indicam que, na base da estrutura, praticamente todos os empregos criados foram com carteira assinada, no que retomamos o argumentado no primeiro capitulo: embora tenhamos experimentado uma formalização que não veio acompanhada da cesta completa de direitos outorgada pela CLT, estamos diante de um padrão de geração de empregos que tem proporcionado a inclusão de um elevado contingente de trabalhadores no mercado e, embora seja certo que sejam postos inferiores no interior da estrutura ocupacional, tratam-se de relações regularizadas. No tocante à pobreza, isto terá importantes implicações.

\subsection{Uma primeira tentativa de discussão com a literatura}

Os resultados e as interpretações que apresentamos acima nos permitem travar um diálogo com a literatura revisada nos capítulos anteriores. Retomando os principais 
achados, podemos dizer que os anos 1990 foram marcados por um processo de polarização ocupacional, fortemente influenciado pelas alterações na demanda por credenciais educacionais mais elevadas e pelo tipo de atividade econômica que se estabeleceu na RMSP na esteira da abertura econômica, da queda do emprego industrial e da flexibilização das relações de trabalho num contexto de forte estagnação econômica.

Como salientamos, estes resultados vão parcialmente de encontro àquilo que a literatura internacional designou como um processo de transição da demanda em contextos marcados por fragilização da proteção social, produzindo incentivos institucionais para a criação de bons empregos no topo da estrutura e de empregos menos valorizados na sua base. Além disso, destaca-se, no contexto, o forte aumento do desemprego, puxado em grande medida pela estagnação econômica, mas também em virtude da redução dos custos associados à demissão dos trabalhadores assalariados em um cenário de reestruturação micro-organizacional. Não por acaso, assistimos ao aumento da informalidade e da rotatividade no interior do mercado de trabalho, esta com novos padrões a partir da década de 1990.

É importante destacar, contudo, que o ponto de partida da nossa análise se distingue em larga medida daqueles que orientou os analistas que se debruçaram sobre os países avançados e suas metrópoles, os quais experimentaram o inicio do processo de reestruturação produtiva a partir de meados da década de 1970. A despeito de evidentes diferenças entre os contextos nacionais, pode-se dizer que não apenas o peso do emprego industrial era, neles, substancialmente maior, como também o era o peso do assalariamento formal. O processo de polarização que foi identificado em vários desses países, portanto, partiu de uma estrutura fortemente consolidada nos estratos médios, com elevado padrão de consumo e algum grau de heterogeneidade interna.

Na Região Metropolitana de São Paulo, o ponto de partida (em nossa análise, localizado no ano de 1991) já era uma economia fortemente dependente do setor de serviços e com um elevado grau de informalidade. Além disso, como buscamos ressaltar anteriormente, tratava-se de um mercado sustentado em uma proteção ao trabalho estratificada e historicamente vinculada ao setor formal, embora os benefícios já tivessem sido ampliados ao longo dos anos 1980 (como a incorporação de autônomos, dos 
empregados rurais, etc.). Por outro lado, é também relevante reconhecer que, ainda no início dos anos 1990, a cobertura do sistema de proteção era escassa e fragmentada, o que sustenta a afirmação de que se podemos reconhecer algum movimento de "desmercantilização" do trabalho, entre nós ela se dera apenas parcialmente e estava longe de se universalizar. Acreditamos que tais aspectos tenham condicionado fortemente o padrão que identificamos nas paginas acima.

Na ultima década, observamos um padrão de evolução da estrutura ocupacional fortemente alavancado pelo estrato intermediário, no que julgamos ser uma evolução qualitativa em relação ao cenário dos anos de 1991 e 2000. Entretanto, ao mesmo tempo em que diagnosticamos essa evolução, percebemos também a menor diferenciação na absorção das credenciais educacionais até o Ensino Médio, o que equivale a reconhecer uma tendência à menor valorização da escolaridade formal a partir da evolução da estrutura ocupacional neste padrão que se estabelecera.

Do ponto de vista teórico, seria de se supor que este padrão sinalizaria no sentido de uma desvalorização da escolarização formal, criando parte dos condicionantes institucionais para uma espécie de "low-skill equilibrium", pelo menos no tocante à relação entre o tipo de emprego criado e os incentivos à escolarização. A lógica é de que, num contexto em que a mão de obra é pouco qualificada, as firmas não teriam incentivos para criar postos que exigem maior qualificação. Do lado dos indivíduos, sabendo que podem ocupar posições semelhantes àqueles que têm maior escolaridade, criava-se um incentivo adverso para o investimento em qualificação ${ }^{53}$.

Para finalizar, nos anos 2000 teve lugar um crescimento largamente ancorado no processo de flexibilização das relações de trabalho da década anterior, como ressaltamos anteriormente, e que se associa ao crescente processo de formalização que teve lugar na segunda parte da década de 2000. Mesmo que ancorado em boa parte em ocupações de base no que concerne aos rendimentos (de até 1 ou 2 salários mínimos), é notável o crescimento maciço dos postos situados no miolo da distribuição ocupacional.

\footnotetext{
${ }^{53}$ As perspectivas teóricas que tratam do low-skill equilibrium são muito mais complexas e esta digressão sintética está longe de lhes ser fiel na sua totalidade. Estamos apenas apresentando o que nos parece ser, parcialmente, uma tendência dos anos 2000 na RMSP, a partir dos dados que apresentamos. Para mais detalhes ver: Schneider (2009).
} 
As implicações que isso traz para a pobreza e como se articula à proteção social na base da pirâmide, discutimos a seguir.

\subsection{Estrutura ocupacional, proteção social e pobreza}

Diagnosticamos nas seções anteriores os principais condicionantes da evolução da estrutura ocupacional nas décadas de 1990 e 2000. Agora cabe identificar de que maneira esta evolução contribuiu para o comportamento da pobreza no período e como esses achados podem ser articulados ao tema da proteção social na base da pirâmide. Como ressaltamos em páginas anteriores, utilizaremos a linha de pobreza estabelecida pelo Governo Federal, para o ano de 2010. Chamaremos de "pobres" aqueles indivíduos elegíveis para o recebimento do beneficio do Programa Bolsa Família, ou seja, cuja renda domiciliar per capita não ultrapassava $\mathrm{R} \$ 120,00$ em valores de 2010; e de "vulneráveis" aqueles elegíveis ao cadastramento no CadÚnico (renda domiciliar per capita entre \$120,00 e R255,00).

A Tabela 6 apresenta a proporção dos estratos de renda para os anos de 1991, 2000 e 2010, bem como alguns indicadores relativos ao mercado de trabalho. A proporção de famílias "pobres" sobe 1,7 p.p de 1991 a 2000, para cair 0,5 p.p. em 2010. Já os indicadores dos vulneráveis apresentam um comportamento mais oscilante. De 13,3\% em 1991, cai para 13,7\% em 2000 e para 9,7\% em 2010. Somando esses dois grupos, os percentuais são $20,8 \%, 22,1 \%$ e $18,1 \%$ na sequencia dos anos, com o último decênio configurando uma queda não desprezível da ordem de quatro pontos percentuais.

Tabela 6 - Evolução dos estratos de renda e proporção de PEA/PIA e Ocupados/PIA nos domicílios, segundo faixa de RDPC na RMSP, 1991-2010

\begin{tabular}{|c|c|c|c|c|c|c|c|c|c|c|c|c|}
\hline \multirow{3}{*}{ Faixas de Renda } & \multicolumn{4}{|c|}{1991} & \multicolumn{4}{|c|}{2000} & \multicolumn{4}{|c|}{2010} \\
\hline & \multirow{2}{*}{$\mathrm{N}$} & \multirow{2}{*}{$\%$} & \multicolumn{2}{|c|}{ Proporção } & \multirow{2}{*}{$\mathrm{N}$} & \multirow{2}{*}{$\%$} & \multicolumn{2}{|c|}{ Proporção } & \multirow{2}{*}{$\mathrm{N}$} & \multirow{2}{*}{$\%$} & \multicolumn{2}{|c|}{ Proporção } \\
\hline & & & PEA/PIA & Ocup/PEA & & & PEA/PIA & Ocup/PEA & & & PEA/PIA & Ocup/PEA \\
\hline Até $\mathrm{R} \$ 120$ & 200597 & 7,1 & 0,45 & 0,44 & 385532 & 8,8 & 0,62 & 0,23 & 174075 & 8,3 & 0,25 & 0,27 \\
\hline Mais de $R \$ 120$ a $R \$ 255$ & 479500 & 3,7 & 0,57 & 0,59 & 668555 & 13,3 & 0,68 & 0,51 & 522928 & 9,7 & 0,60 & 0,56 \\
\hline Mais de $R \$ 255$ a $R \$ 510$ & 941153 & 25,5 & 0,64 & 0,65 & 1188942 & 24,6 & 0,68 & 0,61 & 1223358 & 22,9 & 0,68 & 0,70 \\
\hline Mais de $R \$ 510$ a $R \$ 1020$ & 988571 & 26,1 & 0,70 & 0,70 & 1211318 & 24,6 & 0,71 & 0,69 & 1499785 & 27,1 & 0,75 & 0,80 \\
\hline Mais de $R \$ 1020$ a $R \$ 2040$ & 614552 & 16,2 & 0,72 & 0,73 & 756392 & 15,4 & 0,72 & 0,74 & 920932 & 16,8 & 0,76 & 0,82 \\
\hline Mais de $R \$ 2040$ & 430531 & 11,4 & 0,76 & 0,78 & 659061 & 13,2 & 0,76 & 0,79 & 851380 & 15,1 & 0,81 & 0,86 \\
\hline Total/Média & 3654904 & 100,0 & 0,61 & 0,67 & 4869800 & 100,0 & 0,70 & 0,63 & 5192458 & 100,0 & 0,71 & 0,75 \\
\hline
\end{tabular}

Fonte: Microdados dos Censos Demográficos (IBGE), 1991, 2000 e 2010. Elaboração própria. 
Analisemos a proporção de pessoas na PEA em relação à PIA ${ }^{54}$ no interior das famílias, o que poderíamos chamar de uma "taxa de participação da família". Em 1990, essa taxa é de 45,0\%, em 2000 de 62,0\% e em 2010 de meros 25,0\%. O resultado de 2000 é relativamente esperado, tendo em vista a elevada taxa de desemprego naquele momento; entretanto, e mais do que isso, ele é uma evidencia de como as pessoas estavam "presas ao mercado", premidas a ali buscar a sua sobrevivência, tal como ressaltamos no primeiro capitulo, com base em Guimarães (2006).

Por outro lado, a diferença entre 1991 e 2010 é bastante significativa, ainda mais se atentarmos para o fato de que o desemprego no primeiro ano é sensivelmente inferior ao segundo. Tudo mais constante, deveríamos esperar que um aumento nas taxas de desemprego viesse acompanhado de um incremento nas taxas de participação, o que se evidencia de certa forma na diferença entre a elevada taxa de participação e a baixíssima proporção de ocupados em relação ao número de adultos no ano 2000 (62,0\% contra 23,0\%). Mas a comparação entre 1991 e 2010 mostra uma queda abrupta na intensidade com que as famílias "pobres" vão ao mercado de trabalho que, diga-se de passagem, se mostrava bastante atrativo no ultimo ano.

Poderíamos argumentar na direção de que o aumento da capilaridade da proteção social à pobreza (em especial das políticas de transferência condicionada de renda) teria minimizado o papel do mercado de trabalho enquanto único lócus do acesso aos meios de sobrevivência? Cremos que não, e por dois motivos. Em primeiro lugar, como alguns estudos já trataram de mostrar (Teixeira, 2008; Leichsenring, 2010), porque é difícil sustentar que os baixos valores concedidos às famílias pelas políticas de transferência de renda atuariam como um desincentivo à inserção no mercado de trabalho, especialmente na RMSP. Em segundo lugar, ainda percebemos mais de 90.000 trabalhadores cuja renda do trabalho é de até $\mathrm{R} \$ 100,00$ (valor máximo do benefício do PBF em 2010) e, ao analisarmos a "taxa de participação da família" nos dois estratos de renda inferiores, mas separando entre aquelas que recebem o beneficio do Programa Bolsa Família e aquelas que não recebem, no Censo de 2010, percebemos que as primeiras tendem a ir mais ao mercado do que as segundas ${ }^{55}$. Desta forma, somos tentados a indicar que o beneficio do Programa permite, em alguma medida, que os indivíduos tenham maiores

\footnotetext{
${ }^{54}$ Foram considerados apenas os maiores de 15 anos.

55 Os valores são: Família pobres beneficiárias do PBF: 0,55; Famílias pobres não beneficiárias do PBF: 0,29. Fonte: Microdados do Censo Demográfico de 2010 (IBGE). Dados trabalhados pelo autor.
} 
possibilidades do que os pobres não beneficiários de acessarem os meios de obtenção de emprego, em especial aqueles relacionados à procura de trabalho e acesso a outras políticas, como as de qualificação de mão de obra.

Em 1991, quase metade dos adultos das famílias pobres estava trabalhando (44,0\%), ao passo que em 2010 este percentual é de 27,0\%. Ao associarmos estes resultados às transformações no mercado de trabalho que salientamos nas paginas anteriores, percebemos a tendência à melhora qualitativa dos empregos gerados e ao aumento dos salários na base da estrutura. Mais do que isso, todavia, o resultado mostra que a redução das taxas de pobreza se deu em grande medida pelas vias do mercado de trabalho, por um lado, ao passo que a pobreza passa a se constituir em grande medida como uma situação justamente daqueles que se encontram dele excluídos.

Os indicadores das famílias "vulneráveis", entretanto, não podem passar despercebidos. A participação nesse estrato é muito menos variável - sendo em 2010 superior a 1991 parecendo indicar que aqueles que se encontram no limiar da pobreza (os cadastrados no CadUnico não elegíveis ao $\mathrm{PBF}$ ) não apenas continuam a depender em larga medida do mercado, mas que esta relação se alterou em menor intensidade do ponto de vista da proteção social. Ou seja, se o mercado se desvincula da pobreza em certo em alguma intensidade, o mesmo não é verdade para aqueles que consideramos em situação de "vulnerabilidade", de modo que nesse ponto da distribuição as políticas tem que lidar concomitantemente, e em maior grau, com a ambígua situação de "vulnerabilidade e trabalho". Por outro lado, o fato deste grupo ter se reduzido consideravelmente no ano de 2010 sugere a conclusão de que, como estamos argumentando, foi justamente por meio do trabalho que aproximadamente 145.000 famílias superaram a condição de "vulnerabilidade".

O Gráfico 21 abaixo permite corroborar esses pontos. Para os "pobres", os resultados seguem a mesma tendência da Tabela 6 anterior. Não apenas cresce o percentual de "pobres" sem trabalho, como também aqueles que estão desocupados e os que estão fora da PEA. No sentido contrário, diminui a proporção de pessoas ocupadas em situação de pobreza (3,0\% em 1991, 2,7\% em 2000 e 1,1\% em 2010). 
Gráfico 21 - Indicadores do mercado de trabalho para indivíduos "pobres" e "vulneráveis", RMSP; 1991-2010

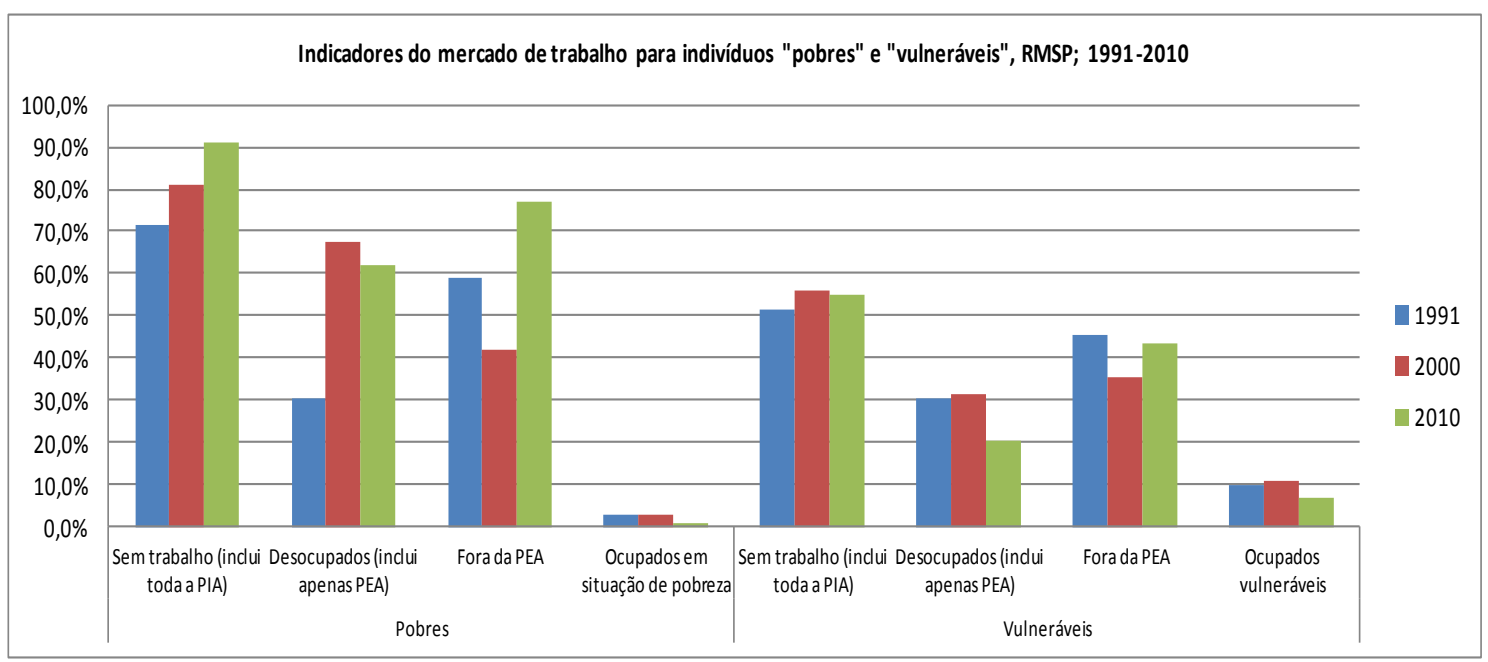

Fonte: Microdados dos Censos Demográficos (IBGE), 1991, 2000 e 2010. Elaboração própria.

Com relação aos "vulneráveis", é interessante o fato de que embora a proporção de pessoas sem trabalho seja praticamente a mesma em 2000 e 2010, a diferença na taxa de desocupação e de "não participação" é consideravelmente menor no último ano. Concomitantemente, notamos uma queda no percentual de pessoas ocupadas que se encontram em situação de vulnerabilidade, evidenciando novamente que a queda do tamanho relativo deste grupo se deu em boa medida via obtenção de empregos mais bem remunerados.

Se estes dados permitem tecer as considerações anteriores, e sem duvidas instigantes, a respeito da esfera de atuação da política de combate à pobreza, o que poderíamos dizer da sua relação com a evolução da estrutura ocupacional? Apenas retomando brevemente, a década de 1990 foi marcada por uma guindada polarizante seguida do crescimento do desemprego, num ambiente pouco receptivo aos menos qualificados. Nos 2000, uma queda do desemprego e um salto qualitativo da estrutura ocupacional, com a incorporação de um alto contingente de trabalhadores com menos de 8 anos de estudo e, o que é mais importante, não apenas no quintil inferior.

Desta forma, podemos colocar à prova às nossas hipóteses que tratam de observar como a evolução da estrutura ocupacional se associa ao comportamento da pobreza e como 
ambas se articulam à esfera de atuação da proteção social de combate à pobreza (hipóteses (2.1 e 3.1).

Repetimos, assim, o mesmo exercício anterior, baseado na observação dos saldos dos quintis, mas agora incorporando a dimensão da renda domiciliar per capita dos trabalhadores ${ }^{56}$.

Gráfico 22 - Evolução da estrutura ocupacional segundo estratos de renda domiciliar per capita, RMSP; 1991-2010

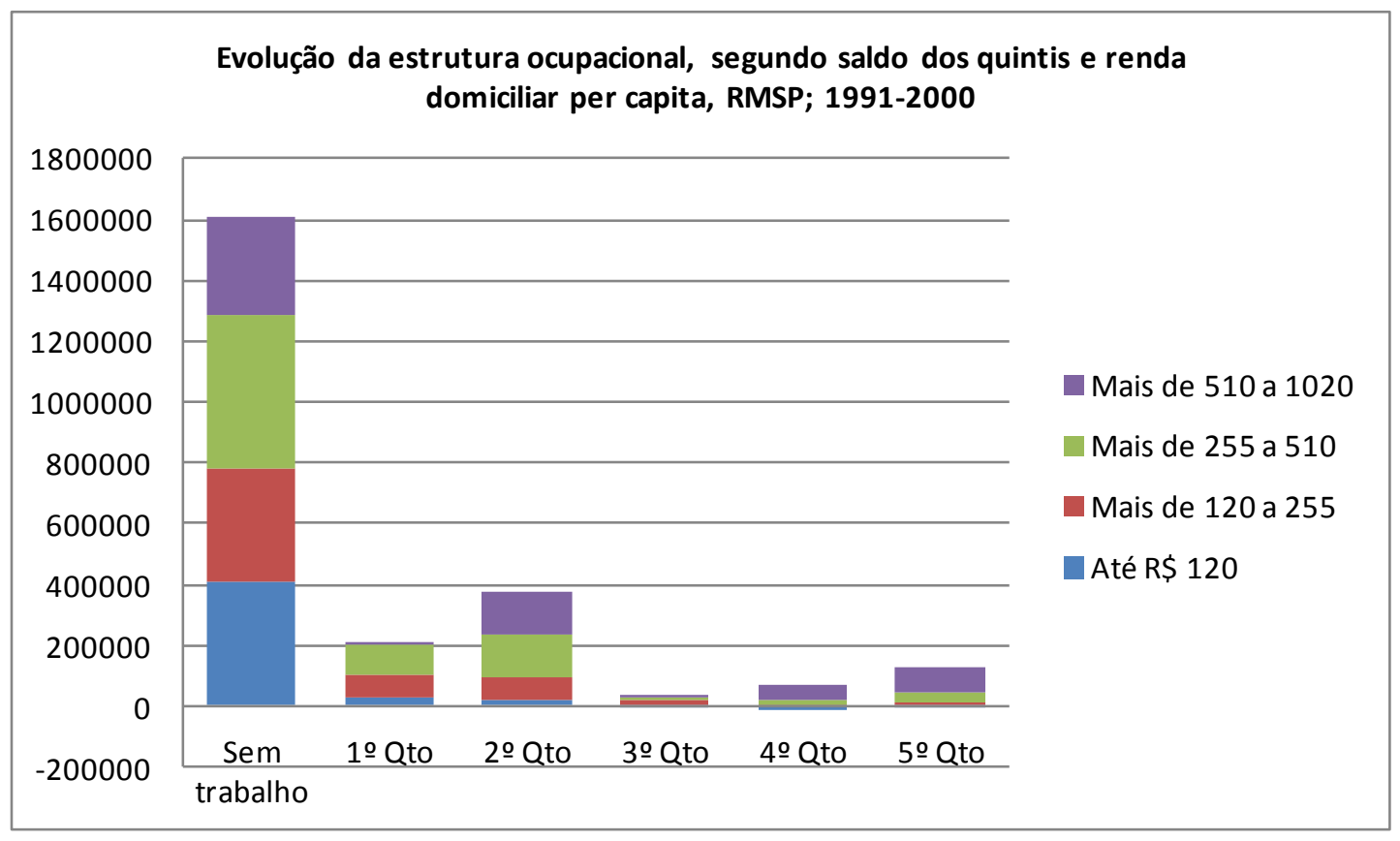

Fonte: Microdados dos Censos Demográficos (IBGE), 1991, 2000 e 2010. Elaboração própria.

Como bem mostra o Gráfico 22 acima, na década de 1990 o saldo de pessoas sem trabalho é de pouco mais de 1,6 milhão, sendo que desses aproximadamente 400.000 estavam em situação de pobreza e 380.000 de vulnerabilidade. E, ainda no primeiro e segundo quintis, observamos um saldo positivo de trabalhadores "pobres" e "vulneráveis" que somados chegam à casa dos 200.000. Havíamos hipotetizado que a evolução da estrutura ocupacional se associaria à incidência da pobreza em virtude de ocupações mal remuneradas na base da estrutura e do baixo valor do salário mínimo (hipótese 2.1). De fato, ao analisarmos a renda domiciliar per capita e a renda do trabalho dos trabalhadores pobres e vulneráveis situados nos dois primeiros quintis,

\footnotetext{
56 De modo a minimizar as variações no comportamento da PEA, o Gráfico 22 contempla todas as pessoas acima de 15 anos.
} 
vemos que os valores são extremamente baixos. Dentre os pobres, essas médias são de $\mathrm{R} \$ 83,00$ e $\mathrm{R} \$ 354,00$ em valores de 2010. Para os vulneráveis, de $\mathrm{R} \$ 190,00$ e $\mathrm{R} \$ 505,00$, respectivamente.

Esse é um resultado aparentemente óbvio: afinal, se os valores não fossem tão baixos, essas pessoas não se encontrariam em situação de pobreza ou vulnerabilidade. Por outro lado, são valores consideravelmente mais baixos do que o valor do salário mínimo (em valores de 2010) e da linha de corte do PBF, que adotamos com linha de pobreza.

Mas há mais do que isso, e aqui voltamos às considerações a respeito de como a demanda expeliu os menos escolarizados dos diversos grupos ocupacionais. Em 2000, das pessoas com mais de 25 anos abaixo da linha de pobreza, 68,1\% tinham Ensino Fundamental Incompleto. Dentre os vulneráveis, esse percentual era de 65,7\%, enquanto que a média geral era de 40,0\%. Se fizermos o exercício contrário, notamos que, das pessoas com Ensino Fundamental completo, 12,8\% estavam em situação de pobreza e 20,9\% de vulnerabilidade, ao passo que a média geral, como vimos anteriormente, era de $7,1 \%$ e $13,7 \%$, respectivamente. Ou seja, se salários e nível de emprego são centrais para se entender o risco de estar na pobreza ou em situação vulnerável, não é apenas nesses aspectos que devemos encontrar os fatores explicativos centrais, mas na própria forma como a evolução da estrutura ocupacional se fez, mostrando-se mais ou menos propensa a incorporar em especial os menos escolarizados.

Quanto à escassez da proteção social na base da pirâmide, embora os dados não permitam confirmar empiricamente, o fato de que a taxa de participação entre os mais pobres é muito alta, evidencia a necessidade da busca pelo trabalho enquanto único meio de acesso ao bem estar. E, novamente aqui, podemos nos apoiar na literatura pertinente que já havia diagnosticado essa baixa capilaridade da proteção social no período. Mais do que isso, "estar trabalhando" nos anos de 1991 e 2000 estava longe de proporcionar o alivio da pobreza. Trabalho e proteção social na base da pirâmide, assim, atuavam como vetores que apontava para direções opostas no enfrentamento da pobreza, mas donde o público era razoavelmente semelhante.

Já na década de 2000, o panorama se altera. O saldo negativo do "não trabalho" é de mais de 500.000 trabalhadores, dos quais mais de 200.000 "vulneráveis", embora ainda 
seja possível observar um saldo positivo de quase 150.000 desocupados em situação de pobreza. Os resultados do primeiro e segundo quintis, por sua vez, mostram que o mercado de trabalho deixa de comportar mais de 200.000 trabalhadores "pobres" e "vulneráveis", o que creditamos, novamente, ao desenvolvimento qualitativo do mercado.

Gráfico 23 - Evolução da estrutura ocupacional, segundo saldo dos quintis e estratos de renda domiciliar per capita, RMSP; 1991-2010

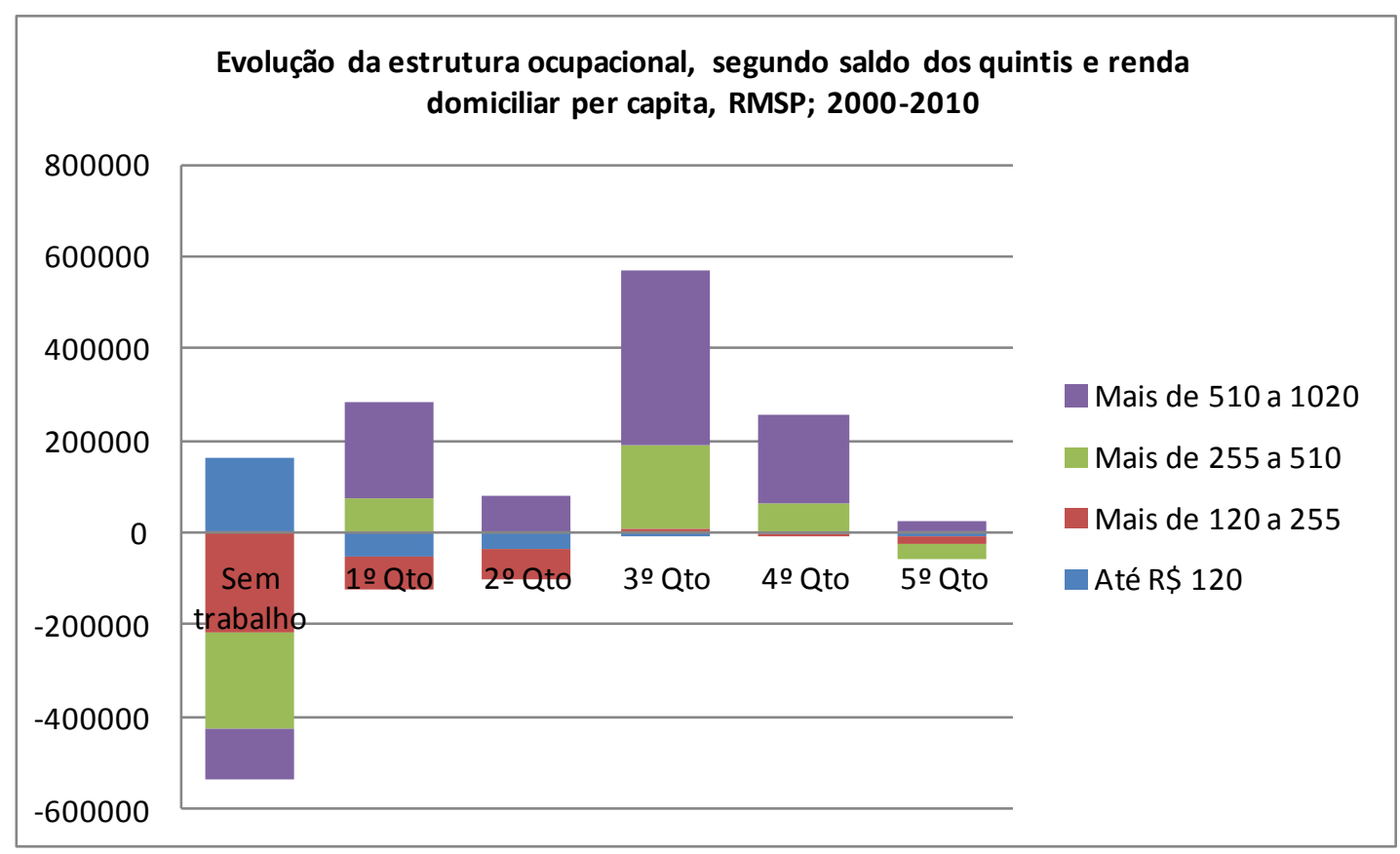

Fonte: Microdados dos Censos Demográficos (IBGE), 1991, 2000 e 2010. Elaboração própria.

A evolução da estrutura ocupacional nos 2000 não apenas se mostrou positiva do ponto de vista da queda do desemprego, mas também contribuiu para a redução da pobreza ao assumir um padrão que incorporou aqueles que estavam mais propensos para tal ao mesmo tempo em que, ao criar melhores ocupações na esteira da expansão do assalariamento formal, reduziu a presença de trabalhadores ocupados em situação de pobreza.

A história contada pelo gráfico acima é a de que (1) houve queda relativa e absoluta do número de indivíduos pobres e vulneráveis e (2) as dinâmicas do mercado de trabalho atuaram de forma a favorecer a saída da pobreza, uma vez que todo saldo positivo de empregos não implicou no aumento do número de indivíduos pobres e, além disso, as 
posições abertas situam-se nos quintis intermediários. Por outro lado, não nega o fato de que a inclusão no mercado de trabalho durante a década de 2000 tenha tido também o seu grau de seletividade.

Sugerimos que aqueles que anteriormente situavam-se abaixo da linha de pobreza e superaram essa condição por meio do trabalho possuíam um mínimo de recursos para acessar os novos postos - dado que a qualificação, a procura de emprego e o deslocamento para trabalhar implicam necessariamente em custos. Ou seja, foram "selecionados" para os postos criados por possuírem requisitos mínimos, sendo plausível sugerir que os beneficiários do Programa Bolsa Família, em virtude do montante recebido do Programa, tivessem mais acesso a tais recursos do que os seus pares não beneficiários (o que se evidencia em alguma medida nas diferenças nas taxas de participação, como mostramos acima). Os últimos, por sua vez, poderiam ter, de saída, menos recursos e possibilidades do que os demais, e a estes a política pública de combate à pobreza deve procurar atingir de maneira eficiente de modo a reduzir as privações decorrentes do modo pelo qual (não) se encontram inseridos no mercado de trabalho.

Por fim, se é certo que o fenômeno da "nova classe média" é discutível, as "fotografias" ponto a ponto nas décadas analisadas permitem sugerir algo mais: não é apenas via formalização, mas também pelo tipo de emprego criado que um elevado contingente de trabalhadores ingressou no campo dos direitos e da proteção social vinculada ao trabalho. Para aqueles que, ainda em situação concomitante de desocupação e pobreza, a expansão da proteção social dirigidas aos mais pobres tem fornecido algum grau de alivio no que se refere à privação de renda, sem excluir o mercado de trabalho como opção viável e desejável de acesso aos mecanismos de reprodução. Por outro lado, ao mostrarmos que dentre os vulneráveis esta relação pouca mudança sofreu, é necessário repensar a extensão da proteção social na base da pirâmide, de modo a alterar a dinâmica da dependência em relação ao mercado de trabalho, que ainda se apresenta como uma condição inevitável. 


\section{CONCLUSÃO}

\subsection{Retomando o debate}

Este trabalho buscou trazer a estrutura ocupacional para o centro do debate sobre mercado de trabalho e pobreza a partir do caso da Região Metropolitana de São Paulo nas décadas de 1990 e 2000. O principal objetivo foi demonstrar que, ao adotarmos esta postura, poderíamos avançar em poder explicativo na compreensão desta relação. $\mathrm{O}$ estudo teve como ponto de partida a vinculação histórica entre o sistema de proteção social no Brasil e a expansão da condição assalariada, entendidos aqui como processos modeladores da relação que se estabeleceu entre pobreza e mercado de trabalho no país.

As teorias das décadas de 1960 e 1970 haviam chamado a atenção para os fenômenos da marginalidade e da informalidade como estruturantes do desenvolvimento do capitalismo brasileiro. O que estava em jogo, à luz daquelas interpretações, eram as possibilidades e os limites de expansão do assalariamento e da proteção social de modo a garantir a universalização da condição cidadã. Cabe salientar que a integração social via assalariamento era tomada como o ponto de chegada vislumbrado na superação ou redução das desigualdades de acesso seja à renda, seja aos serviços de proteção social, os quais permitiriam as condições de reprodução de indivíduos e famílias quando não plenamente inseridos no mercado de trabalho.

Quando, na década de 1990, o país instituiu o seu mais sólido e abrangente marco legal de proteção social, com a Constituição de 1988, uma série de transformações teve lugar, alterando a dinâmica da economia e do mercado de trabalho no Brasil. A Região Metropolitana de São Paulo absorveu rapidamente esses impactos. Não sem razão, posto que ali estava o centro dinâmico da economia do país e fora ali o espaço em que a condição de assalariamento formal atingira os seus níveis mais elevados, em virtude do intenso desenvolvimento industrial que tivera lugar na região. Embora o emprego industrial já viesse declinando desde a década de 1980, ele sofreu uma forte queda nos anos 1990, na esteira da reestruturação micro-organizacional; nem mesmo o crescimento vertiginoso do setor de serviços se mostrou suficiente para compensar essas perdas. Em que pese os momentos de reanimação do crescimento e de queda do desemprego, nos primeiros momentos que se seguiram à estabilização monetária, a taxa 
de desocupação atingiu quase $1 / 5$ da população economicamente ativa da metrópole paulista no ano 2000.

Se do ponto de vista da proteção social a década vinha sendo marcada por um processo de expansão de direitos e benefícios, do ponto de vista das relações trabalhistas o que se assistiu foi um processo de flexibilização dos vínculos. Essas novas formas contratuais foram inicialmente tomadas por boa parte dos interpretes como indicativas de um processo de precarização do mercado de trabalho, argumento que se reforçava ao tempo em que se observava, pela primeira vez em 50 anos, uma inflexão negativa no processo de expansão do assalariamento. Nesse sentido, tanto os estudos mais focados no mercado de trabalho, como aqueles que se dedicaram a entender a relação entre mercado e pobreza, passaram a ressaltar a recorrente ruptura das trajetórias até então relativamente bem delineadas em segmentos do mercado (mesmo se sujeitas à rotação pela quebra de vínculos) e a ausência de horizontes estáveis (seja na reprodução das condições da vida cotidiana, seja de permanência como ocupado no mercado de trabalho). O que se colocava em evidencia, nesse caso, era o enfraquecimento do assalariamento formal e a incapacidade da estrutura do mercado de trabalho de prover tal estabilidade, refletindo-se nas trajetórias individuais e familiares.

Nessa sucessão de interpretações parecia claro, a nosso ver, uma importante mudança no estatuto analítico conferido ao assalariamento formal enquanto categoria de entendimento no interior da lógica argumentativa dos diferentes analistas. Se para os que haviam tratado dos temas de informalidade e marginalidade a expansão do assalariamento era antes de tudo o ponto de chegada vislumbrado, agora era a sua redução o fenômeno a desafiar e que fornecia os parâmetros para as construções interpretativas.

Por outro lado, com a retomada do crescimento nos 2000, ancorado fortemente em ocupações formais (embora sem a cesta de direitos que outrora acompanhara os vínculos CLT), o debate se renovou. Desdobrou-se, entre outras vias, no diagnóstico da possível emergência de uma "nova classe média". Independentemente da pertinência desse entendimento e da existência dessa "nova classe", foi justamente a entrada de um elevado contingente de pessoas sob essas novas institucionalidades que sustentavam os tipos de contrato em expansão no mercado de trabalho (trabalhadores temporários, 
terceirizados, estagiários, intermediados...) que forneceu o mote para esse debate. Assim, e significativamente, o que em boa parte dos países desenvolvidos havia sido tomado como um sintoma de enfraquecimento dos regimes de proteção social e da perda de direitos, aqui podia ser percebido como um movimento, mesmo que restrito, de inclusão de trabalhadores ao mercado de trabalho e de consumo.

Entretanto, não deixa de ser intrigante que a renovação do debate sobre pobreza animado pela necessidade de entender a realidade dos novos institutos de proteção social, criados pela Constituição de 1988 e expandido pelos governos Fernando Henrique Cardoso e, especialmente, Luiz Inácio Lula da Silva -, tenha relegado a segundo plano um tratamento sistematizado dessas importantes transformações que se passavam no interior do mercado de trabalho. Como salientamos no primeiro capitulo, este era sempre tomando como um dado externo (o mercado de trabalho flexível, excludente, instável, precário...) às interpretações que eram (e continuam a ser) produzidas sobre os mecanismos de produção e alivio da pobreza. As transformações na estrutura ocupacional, em especial, estavam entre os grandes ausentes nessas narrativas interpretativas. Esta foi a lacuna que nos propusemos a suprir.

Para tal, nos nutrimos fartamente de uma literatura que, se bem não tenha se dirigido ao tratamento da pobreza, acreditamos que poderia jogar alguma luz para o entendimento da relação entre pobreza e mercado de trabalho. Essa literatura chamou a atenção para como as alterações na demanda e na oferta de trabalho, por um lado, e nas instituições do mercado de trabalho e da proteção social, por outro, ajudavam a explicar os padrões de desigualdade salarial e ocupacional que se haviam estabelecido nos países desenvolvidos e em algumas de suas metrópoles a partir da década de 1970.

Foi partindo dessa literatura, mas balizados pelas especificidades do caso brasileiro, tal como as havíamos salientado no primeiro capitulo, que formulamos nossas hipóteses e conduzimos o estudo empírico, utilizando o caso da Região Metropolitana de São Paulo entre os anos de 1991 e 2010. 


\subsection{Retomando os achados e apontamentos}

Tendo como pano de fundo as transformações da estrutura produtiva, da oferta, das relações de trabalho e do escopo da proteção social na base da pirâmide ao longo dos anos 1990 e 2000, formulamos nossas hipóteses de estudo. Sugerimos que a evolução da estrutura ocupacional na Região Metropolitana de São Paulo havia sido distinta nas duas décadas e que essas distinções poderiam ser elementos com elevado potencial explicativo para melhor compreendermos a relação entre pobreza e mercado de trabalho.

De fato, o que percebemos ao longo dos anos 1990 na RMSP foi um processo de polarização da estrutura ocupacional, movido pelo aumento da demanda por trabalhadores mais qualificados, em contraposição à redução da demanda pelos menos qualificados. Estas transformações na demanda, por sua vez, encontraram nas próprias transformações da atividade produtiva uma de suas principais alavancas, ao mesmo tempo em que as relações de trabalho haviam se flexibilizado desde meados da década.

Chamamos atenção, entretanto, para os tipos de ocupação que foram majoritariamente criadas nesse contexto, em conjunto com a escassa proteção social no combate à pobreza. Além da elevação do desemprego e do baixo valor relativo do salário mínimo, também o padrão de evolução da estrutura ocupacional foi um fator determinante para o crescimento da pobreza no período.

Esse aspecto fica ainda mais claro quando observamos o padrão que se estabeleceu ao longo dos anos 2000. Diferentemente do que supúnhamos, o carro-chefe da expansão do emprego na RMSP no período foram as ocupações intermediárias. Desta forma, a redução da pobreza esteve fortemente associada ao fato de que a estrutura ocupacional incorporou, e em ocupações de relativa qualidade - porque situadas no meio da distribuição - um elevado contingente de trabalhadores. Mais do que isso, boa parte desses trabalhadores eram os menos qualificados que, na década anterior, viram suas oportunidades no mercado de trabalho diminuir em virtude do modo como evoluiu o padrão de geração de empregos.

É importante salientar, ainda, embora não tenhamos dados conclusivos para tal, as diferenças de cobertura da proteção social aos mais pobres. Mesmo sem os meios para 
confirma-lo empiricamente, somos tentados a sugerir, a partir da literatura revisada, que ao longo da década de 1990, em função de uma escassa cobertura, aqueles que foram desligados do mercado de trabalho se encontravam mais propensos a vivenciar uma condição de pobreza. Nos anos 2000, o fato de um grande número de trabalhadores ter deixado a condição de vulnerabilidade via acesso a ocupações mais bem remuneradas, associado às maiores taxas de participação das famílias beneficiárias do Programa Bolsa Família, sugere que foi pelo mercado de trabalho que a redução da pobreza encontrou um de seus principais condutos propiciadores. Por outro lado, ao mostrarmos que a condição daqueles que se encontram no limiar da pobreza pouco se alterou em relação à dependência do mercado de trabalho, vimos que é necessário repensar (no sentido de sua expansão) a proteção social na base da pirâmide.

Como ressaltamos a partir da literatura retratada no segundo capitulo, este movimento de maior expansão pode ser uma interessante alternativa não apenas pelo fato óbvio de que contribui para a redução da pobreza, mas também por constituir mecanismo institucional que atua como vetor de desenvolvimento qualitativo da estrutura ocupacional. Nesse caso, é perfeitamente cabível sugerir a possibilidade de complementaridades institucionais não apenas em relação ao modo como o sistema educacional se associa à estrutura produtiva, mas também de como a proteção social na base da pirâmide pode, ela também, jogar nesse processo.

Esses achados permitem um diálogo com a literatura no sentido de termos podido documentar como a estrutura ocupacional pode ser utilizada para melhor compreenderse a relação entre pobreza e mercado de trabalho. Retomando parte dessa literatura que diagnosticou um processo de polarização ocupacional nos países desenvolvidos, em especial naqueles em que as instituições do mercado de trabalho são mais frágeis, somos forçados a sugerir que o contexto de reestruturação micro-organizacional e de flexibilização das relações de trabalho ao longo dos anos 1990 foi um aspecto fundamental para o processo de polarização ocupacional que se passou na RMSP entre 1991 e 2000. E, mesmo que não se possa defender a existência de uma polarização da estrutura de classes (Marques et al, 2013), o saldo da década mostra uma forte polarização das ocupações que foram criadas. A estrutura produtiva da metrópole se reorganizou rapidamente a partir de um polarizado setor de serviços e a demanda por trabalho claramente se enviesou no sentido de maior valorização dos mais 
escolarizados, ao passo que os menos qualificados viram suas oportunidades no mercado de trabalho declinar. O resultado, como mostramos, foi um cenário de elevado desemprego dos estratos educacionais inferiores, os quais, em boa parte, passaram a viver em condição de pobreza.

Ao longo dos anos 2000, por outro lado, não apenas o saldo da geração de empregos foi muito mais elevado, como também foram na sua maioria "boas ocupações" (a se considerar sua posição na estrutura ocupacional) e que passaram a diferenciar em menor grau os indivíduos por suas credenciais educacionais. Colocando-o em outros termos, a estrutura ocupacional da RMSP parece ter se desenvolvido ao longo dos anos 2000 no sentido de criar ocupações intermediárias nas quais os níveis de escolaridade formal eram menos valorizados; justamente por isso, ocorreu a reincorporação de um elevado contingente de trabalhadores com ensino fundamental incompleto nas mesmas ocupações de trabalhadores com ensino fundamental e médio completo. Partindo desse achado, arriscamos indicar, no capitulo precedente, que é possível que essa baixa diferenciação da qualificação esteja motivando um circulo vicioso de criação de ocupações pouco especializadas do ponto de vista do sistema produtivo, o que tenderia a uma situação de "low-skill equilibrium”. Sustentar tal ideia, entretanto, não é possível a partir dos nossos resultados, de modo que preferimos deixar este ponto em aberto.

Do ponto de vista da pobreza, por outro lado, este padrão teve efeito positivo na medida em que incorporou justamente aqueles que se encontravam mais propensos a vivenciala. E o fez em ocupações que não apenas poderiam ser consideradas de boa qualidade, porque situadas no meio da distribuição, mas que traziam consigo os benefícios das relações de trabalho formalizadas. Vale dizer, os pobres que ao longo da década de 2000 tinham mais recursos para acessar os meios de obtenção de trabalho foram largamente beneficiados em virtude da expansão do período. Nesse sentido, sugerimos que os beneficiários do Programa Bolsa Família, por contarem com o beneficio que lhes era concedido pela política, tiveram maiores chances de chegar aos novos postos criados em contraposição aos seus pares não beneficiários.

Em outras palavras, estamos a sugerir uma interpretação que incorpora dois vetores distintos, mas complementares, que alteraram a relação entre pobreza e mercado de trabalho ao longo dos anos 2000. De um lado, uma forte expansão do emprego e das 
ocupações intermediárias. De outro, as distintas posições ocupadas pelos "pobres" no ponto de partida da competição pelos novos postos criados. É aí que, ao nosso ver, podemos traçar profícuas considerações no que tange à relação que buscamos estudar ao longo desta dissertação, a saber: estrutura ocupacional, pobreza e proteção social.

A possibilidade de acesso aos novos postos criados fica documentada nas maiores taxas de participação dos beneficiários do Programa Bolsa Família, evidenciando que a propensão a se inserir no mercado encontra no grupo de "pobres" uma clara diferenciação a depender do grau em que os indivíduos e famílias são atendidos pela política pública. Se não é possível dizer de um condicionamento da evolução da estrutura ocupacional pelo Programa strictu sensu, por um lado, por outro sugerimos que o Programa pode alterar as condições de acesso a recursos que são valorizados no momento em que os indivíduos se dispõem a buscar no mercado os meios de sobrevivência e reprodução. E isto nos permite ir mais além. Na medida em que os "pobres" contam com recursos que outrora lhe eram negados (a saber, o beneficio do Programa), uma maior margem de escolha emerge no horizonte das possibilidades de engajamento no mercado de trabalho. Seja por facilitar os mecanismos de acesso aos novos postos decorrentes da expansão, seja por poder negar qualquer tipo de atividade que lhes pareça suficientemente menos atrativa do que o reduzido montante concebido pelo beneficio. Obviamente, a primeira opção nos parece ser a mais recorrente, visto que, num mercado dinâmico como o da Região Metropolitana de São Paulo, é pouco sustentável a ideia de que o beneficio do Programa seja suficiente para que um indivíduo venha a negar qualquer oportunidade de trabalho, a não ser em casos excepcionalmente mal remunerados.

E aí voltamos à década de 1990. Mesmo num cenário de escassez da proteção social e elevado desemprego, encontramos no mercado um elevado número de pobres que estavam trabalhando. Em outras palavras, a pobreza não era unicamente decorrente da situação de desocupação e/ou inatividade, mas era condição mesma de um sem número de trabalhadores ocupados. E, sejam a estes trabalhadores ou àqueles que se encontravam excluídos do mercado, o tímido escopo da proteção social se mostrava claramente insuficiente para o alivio das privações decorrentes da situação de pobreza. 
Considerando as duas décadas - 22 anos da Constituição de 1988 -, uma série de transformações teve lugar, e delas buscamos tratar analisando cada um dos decênios separadamente. Mas qual seria, ao final, o saldo líquido do período?

A análise agregada sugere, ao nosso ver, uma estrutura ocupacional menos polarizada ao final dos anos 2000 do que poderíamos observar no inicio dos anos 1990, indicando uma sorte de desenvolvimento qualitativo do mercado e, mais do que isso, um contexto marcado por menores distancias sociais. A redução dessas distancias, como tentamos mostrar a partir do fluxo das ocupações, encontrou boa parte de suas razoes nas transformações da estrutura produtiva, na dinâmica da regulação das relações de trabalho e na evolução da proteção social na base da pirâmide. De certa forma, podemos dizer que o resultado é positivo do ponto de vista da forma em que os indivíduos encontram no mercado os meios de sobrevivência, por um lado, e para aqueles que, dele excluídos (ou nele "mal inseridos"), necessitam do (e tem tido acesso ao) beneficio da política social de combate à pobreza.

Entretanto, o cenário futuro se apresenta relativamente ambíguo. Em primeiro lugar porque, como mostramos, as tendências recentes parecem se sustentar em ocupações que tem diminuído o grau de diferenciação da absorção das credencias educacionais. Não se trata apenas dos retornos salariais mas, mais do que isso, das ocupações exercidas. E, nesse sentido, é suspeitável que no longo prazo se sustente o modo como as expectativas individuais de investimento educacional sejam condizentes com aquilo que a estrutura ocupacional tem a oferecer enquanto postos de trabalho. Certamente isso dependerá das novas dinâmicas de evolução da estrutura ocupacional, mas somos tentados a indicar que há pouco espaço para mudança se tomarmos por base os tipos de ocupações criadas nos últimos anos. O prognóstico pouco otimista, nesse caso, seria um afrouxamento dos mecanismos estruturais e simbólicos de integração social e um enfraquecimento das estruturas normativas de coesão.

De outro lado, como bem tentamos mostrar, o movimento recente foi claramente bem sucedido no que se refere à redução da pobreza e da incorporação de um elevado número de trabalhadores aos estratos ocupacionais superiores. Mesmo que não possamos dizer que aqueles que se beneficiaram da evolução qualitativa da estrutura ocupacional constitui uma "nova classe média", podemos, sim, afirmar que, 
relativamente aos anos de 1991 e 2000, eles se encontram em ocupações melhores do ponto de vista da sua posição na estrutura ocupacional e de acesso a direitos. E, novamente ressaltamos, é justamente por meio do acesso a tais posições que muitos deles deixaram a situação de pobreza.

Por outro lado, devemos ter em mente o fato de que, como ressaltamos no primeiro capitulo, as pessoas tendem a ficar cada vez menos tempo nas ocupações, mesmo no setor formal. Desta forma, o prognóstico que nossos dados permitem formular com relação à evolução da estrutura ocupacional não nos autoriza dizer nada sobre a estabilidade desses trabalhadores. O máximo que podemos fazer é calibrar nossas interpretações no sentido de admitir que a estrutura ocupacional se encontra mais fluida no que concerne à troca de posições, e admitir que há processos dessa natureza que perpassam o mercado de trabalho e que não conseguimos captar.

Para concluir, e mesmo correndo o risco de sermos repetitivos, retomamos o ponto de partida da nossa análise, qual seja: o de que integrar a analise da estrutura ocupacional à compreensão do fenômeno da pobreza agrega potencial analítico a essa empreitada. Nesse sentido, esperamos ter mostrado como a estrutura ocupacional é um importante mediador da configuração institucional e das transformações econômicas que esculpem o modo pelo qual a pobreza se articula ao mercado de trabalho. E, mais do que isso, de como é possível pensar numa relação simbiótica entre a expansão da proteção social, o desenvolvimento qualitativo da estrutura ocupacional e a redução da pobreza. 


\section{BIBLIOGRAFIA}

Acemoglu, D. (1999) "Changes in unemployment and wage inequality: an alternative theory and some evidence" The American Economic Review, vol. 89, n5, pp. 12591278.

(2002) "Technical change, inequality and the labor market" Journal of economic literature, vol. $40, \mathrm{n}^{\circ} 1$, pp. 7-72.

Acemoglu, D.; Autor, D. (2010) "Skills, tasks and technologies: implications for employment and earnings" National Bureau of Economic Research, Working Paper 16082. Disponível em: http://www.nber.org/papers/w16082

Arretche, M. (1995) "Emergência e desenvolvimento do Welfare State: teorias explicativas". BIB, $\mathrm{n}^{\circ}$ 39, Rio de Janeiro.

Autor, D.; Levy, F; Murnane, R. (2003). "The skill contento of recent technological change: an empirical exploration" The Quartely Journal of Economics, vol 118, $\mathrm{n}^{\circ} 4$.

Autor, D.; Katz, L; Kearney, M. (2006). "The polarization of U.S. labor market" National Bureau of Economic Research, Working Paper 11986. Disponível em: http://www.nber.org/papers/w11986.

Baltar, P. (1996) "Estagnação da economia, abertura e crise do emprego urbano no Brasil”. Economia e Sociedade, Campina, v 6.

Baltar et al (2010) "Trabalho no governo Lula: uma reflexão sobre a experiência brasileira recente". Global Labor University Working Papers.

Barbosa, A. F. (2008) "A formação do mercado de trabalho no Brasil". Alameda, São Paulo.

Barrientos, A. (2004). "Latin America: Towards a Liberal-Informal Welfare Regime". In: Insecurity and Welfare Regimes in Asia, Africa and Latin America: Social Policy in Development Contexts, ed. Ian Gough and Geof Wood. Cambridge: Cambridge University Press.

Baum, S. (1999). "Social transformations in the global city: Singapore". Urban Studies, Vol. 36

Bicev, J. T. (2010). “Os trabalhadores subcontratados da Região Metropolitana de São Paulo: precariedade ou estabilização?”. Dissertação de Mestrado em Sociologia, Universidade de São Paulo.

Bichir, R. (2011) "Mecanismos federais de coordenação de políticas sociais e capacidades institucionais locais: o caso do Programa Bolsa Família". Tese de Doutoramento. IESP/UERJ. Rio de Janeiro. 
Bittar, M. (2002) “O sistema de proteção social e combate à pobreza". Dissertação de mestrado apresentada ao IUPERJ. Rio de Janeiro.

BRASIL - Ministério do Desenvolvimento Social e Combate à Fome. Disponível em: www.mds.gov.br

Braga, R. (2012) “A politica do precariado. Do populismo à hegemonia lulista". Boitempo. São Paulo.

Bronzo, C. (2005) "Programas de proteção social e superação da pobreza: concepções e estratégias de intervenção". Tese de Doutorado - Sociologia. UFMG/FAFICH. Belo Horizonte.

Bronzo, C., Prates, I. (2012) "Tocando o intangível: explorando o efeito de programas sociais nas dimensões menos tangíveis da pobreza". Cadernos de Gestão Pública, Vol. 17, nº 60, FGV. São Paulo.

Cabannes, R.; Georges, I.; Rizeck, C.; Telles, V. S. (2011). "Saídas de emergencia". Boitempo, São Paulo.

Campolina Diniz, C; Campolina, B. (2007). "A Região Metropolitana de São Paulo: reestruturação, re-espacialização e novas funções”. Revista Eure, Vol. XXXIII, nº 98. Santiago de Chile.

Cappellari, L.; Jenkins, S. P. (2002). "Who stays poor? Who becomes poor? Evidence from the british household panel survey". The Economic journal, v. 112.

Cardoso, A. (1999). "Sindicatos, trabalhadores e a coqueluche neoliberal". FGV, Rio de Janeiro. (2000). “Trabalhar: verbo transitivo". FGV. Rio de Janeiro. (2013). “Ensaios de sociología do mercado de trabalho". No prelo.

Carvalhaes, F. A. (2008) "Micro ou macro? Análise de classes e a queda da desigualdade de renda do trabalho no Brasil". Dissertaçao de Mestrado em Sociologia. Instituto Universitário de Pesquisas do Rio de Janeiro.

Carvalhaes; F.A.; Barbosa, R. J.; Souza, P. H. G. F; Ribeiro, C. A. C; (2013); "Os impactos de geração de empregos e desigualdade de renda: uma análise da década de 2000". Working Paper do Centro de Estudos da Metrópole. Disponível em: http://www.fflch.usp.br/centrodametropole/antigo/static/uploads/wp15.pdf

Castro, J. A.; Modesto, L. (2010). "Bolsa Família 2003-2010: avanços e desafíos". IPEA, Brasília.

Carvalho, J. M. (2005) “Cidadania no Brasil: o longo caminho". Civilização Brasileira, Rio de Janeiro. 
Castel, R. (1998). “As metamorfoses da questão social: uma crônica do salário”. Vozes, Rio de Janeiro.

Cohn, A. (1995). "Políticas sociais e pobreza no Brasil". Planejamento e Políticas Públicas, $\mathrm{n}^{\circ} 12$.

Coleman, J. (1990) “Foundations of social theory”. Harvard University Press. Cambridge.

Comin, A.; Amitrano, C. (2003) "Economia e emprego: a trajetória recente da Região Metropolitana de São Paulo”. Novos Estudos Cebrap, n 66. São Paulo.

Comin, A.; Barbosa, R. J. (2011). "Trabalhar para estudar: sobre a pertinência da noção de transição escola- trabalho no Brasil”. Novos Estudos CEBRAP. v. 91

Costa, M. S. (2005) "O sistema de relações de trabalho no Brasil: alguns traços históricos da sua precarização”. Revista Brasileira de Ciencias Sociais. v. 20. № 59.

Dedecca, C. S. (2002) "Reorganização econômica, emprego e qualificação". Revista de Economia Politica, v. 22, nº 2. São Paulo.

(2005) "Notas sobre a evolução do mercado de trabalho no Brasil". Revista de Economia Política vol. 25, nº 1, pp 94-111.

DiPrete, T. et all (2005). "Work and Pay in Flexible and Regulated Labor Markets: A Generalized Perspective on Institutional Evolution and Inequality Trends in Europe and the U.S." Working paper. Disponivel em: http://www.yale.edu/ciqle/CIQLEPAPERS/DiPrete,\%20work\%20and\%20pay\%20in\%2 Oflexible.pdf

Donadone, J. C. (2009). "Lógica financeira e dinâmica organizacional nos anos 1990: novos donos, novos consultores, outros gerentes". In: Mandadore, A. P. et al "Sociologia econômica e das finanças: um projeto em contrução". Edusc, São Carlos.

Draibe, S. M. (1988) "O Welfare State no Brasil: características e perspectivas" NEPP/UNICAMP [Caderno de Pesquisa $n^{o}$ 8]. Campinas.

(2002) "Brasil: 1980 - 2000: proteção e inseguranças sociais em tempos difíceis". Texto apresentado em Taller Iner-Regional "Protección Social en una era insegura: Un intercambio Sur-Sur sobre políticas socialesalternativas en respuesta a la globalización”. Santiago de Chile.

(2004) "As políticas sociais do governo militar brasileiro:1964-1984", in G. Soares e M. Araújo (orgs) "21 anos de governo militar: balanços e perspectivas". Fundação Getúlio Vargas, Rio de Janeiro. 
(2003) "A política social no período FHC e o sistema de proteção social".

Revista Tempo Social, USP, vol 15, n 2. São Paulo.

Esping-Andresen, G. (1990) “The three worlds of welfare capitalism". Princeton University Press, Princeton.

(1999) "The social foundation of post industrial societies".

Oxford University Press, NY.

Estevez-Abe, M (2008) "Welfare and capitalism in post war Japan". Cambridge University Press, MA.

Fernandes, D (2009) "Race, socioeconomic development and educational stratification in Brazil" Research in Social Stratification and Mobility. v. 22.

Fernandez-Macías, E. (2012). "Job polarization in Europe? Changes in the emplyment structure and job quality, 1995-2007”. Work and occupations. Vol 39.

Faria, V. (1994). "Social exclusion in Latin America: an annotated bibliography". IILS. Disponível em: http//www.ilo-mirror.library.cornell.edu/

Fagnani, E. (1989) "Política Social e pactos conservadores no Brasil: 1964/92". Economia e Sociedade, $\mathrm{n}^{\circ}$ 8, Campinas.

Filguera, F. (1999) "Tipos de welfare y reforma social en America Latina: eficiência, residualismo y ciudadania estratificada". In: Melo, M. A. (org) "Reforma do Estado e mudança institucional no Brasil”. Editora Massangana, Recife.

Franzoni, J. M. (2008) "Welfare Regimes in Latin America: Capturing constellations of markets, families, and policies". Latin America Politics and Society. V. 50, Issue 2.

Freeman, R.; Katz, L. (1995). "Differences and changes in wage inequality". Chicago University Press. Chicago.

Furtado, C. (2006 [1959]) “Formação econômica do Brasil”". Companhia das Letras, São Paulo.

Gallie, D. (org.) (2007) "Employment regimes and the quality of work". Oxford University Press, Oxford.

Gallie, D.; Paugam, S. (2004a) "Welfare Regimes and the experience of unemployment in Europe". Oxford University Press, Oxford.

(2004b) "Resisting marginalization: Unemployment experience and social policy in the European Union”. Oxford University Press, Oxford.

Germani, G. (1978) "Sociologia da Modernização: estudos teóricos, metodológicos e aplicados à América Latina”. Mestre Jou, São Paulo. 
Goos, M.; Manning, A. (2007) "Lousy and lovely jobs: the rising polarization of work in Britain" The Review of economics and statistics, vol 89, n 1

Goos, M.; Manning, A.; Salomons, A. (2009) "Job polarization in Europe" The American Economic Review, vol. 99, n², pp. 58-63.

Goldin, C ; Katz, L. (2008). "The race between education and technology". Harvard University Press, Cambridge, MA.

Granovetter, M. (1973). “The strenght of weak ties". Ammerican Journal of Sociology, 78 (6), p. 1360-80.

Guimarães, N. A (2002) "Por uma sociologia do desemprego". Revista Brasileira de Ciências Sociais, vol 17, $\mathrm{n}^{\circ}$ 50. São Paulo.

trajetórias de trabalhadores”. Editora 34. São Paulo.

(2004) "Caminhos cruzados: estratégias de empresas e (2006) "Novas formas, novas medidas? Desemprego, trajetórias ocupacionais e experiências na produção de informações". São Paulo em Perspectiva, v. 20, nº 4. São Paulo.

(2009) "A sociologia dos mercados de trabalho: ontem e hoje". Novos Estudos CEBRAP, n ${ }^{85}$, São Paulo.

Horizonte.

(2009) “Desemprego: uma construção social”. Argumentvm, Belo

(2011) "O que muda quando se expande o assalariamento (e em que o debate da sociologia pode nos ajudar a compreendê-lo?)". Revista Dados, v. 54, nº4. Rio de Janeiro.

Guimarães, N. A.; Brito, M. M. A.; Barone, L. S. (2013) "Mercado e mercantilização do trabalho: que aprendemos com o caso brasileiro". In: Arretche, M. (2013) "Quanto o Brasil mudou nos últimos 50 anos”. Centro de Estudos da Metrópole (mimeo).

Hamnett, C. (1996). "Social polarization, economic restructuring and welfare state regimes". Urban Studies. vol 33.

Hasenbalg, C.; Valle Silva, N. (2003). "Origens e Destinos: desigualdades socioeconômicas ao longo da vida". TopBooks. Rio de Janeiro.

Hirata, D. (2012). "Vida loka". In: Cabannes et al (op. cit).

Hoffman, H. (1980). “Desemprego e subemprego no Brasil”. Ática, São Paulo.

Huber,E.; Stephens, J. (2001). "Development and crises of the welfare state". Chicago University Press. 
Humphrey, J. (1982). “Fazendo o “milagre"”. Vozes/Cebrap. São Paulo.

Iversen, T. (2005) "Capitalism, democracy and welfare". Cambridge University Press. MA.

Hall, P. ; Soskice, D (2001) “Varieties of capitalism”. Oxford University Press. UK.

Jaccoud, L., Hadjab, P. e Chaibub, P. (2009) "Assistência Social e Segurança Alimentar: entre novas trajetórias, velhas agendas e recentes desafios (1988-2008)". In: IPEA. Políticas sociais - acompanhamento e análise - Vinte Anos da Constituição Federal. Volume $1 n^{\circ} 17$.

Kalleberg, A; (2012). "Job quality and precarious work: clarifications, controversies and challenges". Work and occupations. Vol 39.

Kerstenetzky, C. L. (2012). “O Estado de bem estar na idade da razão: a reinvenção do estado social no mundo comporaneo". Elsevier, Rio de Janeiro.

Kowarick, L. (1975) “Capitalismo e Marginalidade na América Latina". Paz e Terra, Rio de Janeiro.

(2003) "Sobre a vulnerabilidade socioeconômica e civil: Estados Unidos, França e Brasil”. Revista Brasileira de Ciencias Sociais. v. 18, nº 51.

Krein, J. D. (2004) "A reforma trabalhista no governo FHC: análise da efetividade". Revvista do Tribunal Regional do Trabalho. v. 24, $\mathrm{n}^{\circ} 15$.

Lavinas, L. (2003). "Pobreza e exclusão: traduções regionais de duas categorias da prática". Econômica, v. 4., nº 1, p. 25-59. Rio de Janeiro.

Leichsenring, A. (2010). "Precariedade laboral e o Programa Bolsa Família". In: Castro ; Modesto (2010), op. cit.

Lezguizamón, S. A. (2005). "Trabajo y produción de la pobreza en Latinoamerica y el Caribe: estrcutura, discursos y actores". Clacso, Buenos Aires.

Lewis, O. (1992) “Antropologia de la pobreza: cinco famílias". Fondo de Cultura Económica. Ciudad de Mexico.

Machado, A. F.; Ribas, R. P.; Penido, M. (2007). "Mobilidade entre estados da pobreza e inserção no mercado de trabalho: uma análise para o Brasil metropolitano em 2004".

Economia Aplicada, v. 11, no 2. São Paulo.

Machado da Silva, L. A. (1971) "Mercados metropolitanos de trabalho manual e marginalidade". Dissertação de Mestrado, PPGAS do Museu Nacional. UFRJ, Rio de Janeiro.

(1991) "A (des) organização do trabalho no Brasil urbano". São Paulo em Perspectiva, Vol IV, no 3 e 4. São Paulo. 
(2003) "Mercado de trabalho ontem e hoje:informalidade e empregabilidade como categorias de entendimento". In: Ramalho, R.; Santana , M. A.; (op cit)

Mares, I (2003) "The polites of social risk: business and welfare state development" Cambridge University Press, MA.

Marques, E. C. (2010). "Redes sociais, segregação e pobreza". Editora Unesp, São Paulo.

Marques, E. C.; Barbosa, R. J.; Prates, I. (2013). "Transformações socioeconômicas e grupos sociais". In: Marques, E. C. (org): São Paulo nos 2000. No prelo.

Marques, R. M. (1997) “Proteção social e o mundo do trabalho”. Bienal, São Paulo.

Marshal, T. H. (1965) “Cidadania, Classe e status”. Zahar, Rio de Janeiro.

Marx, I. (2007) “A new social question?”. Amsterdam University Press, Amsterdam.

Massey, D., Denton, N. A. (1993). "American Apartheid: Segregation and the making of the underclass". Harvard University Press. Cambridge.

Martins, J. S. (1997). "Exclusão social e a nova desigualdade”. Paulus, São Paulo.

Mattoso, J (1995). “A desordem do trabalho”. Sctitta, São Paulo.

Melo, H. P. (2004). "Gênero e Pobreza no Brasil". AGENDE. Disponível em: Http://www.agende.org.br/.

Medeiros, M. (2001) "A trajetória do Welfare State no Brasil: papel redistributivo das políticas sociais dos anos 1930 aos anos 1990". Texto para discussão 852, IPEA, Brasília.

Merton, R. K. (1970). “Sociologia: teoria e estrutura”. Mestre Jou, São Paulo. (1975). “Análise estrutural em sociologia". In: Blau, P. (org) Introdução ao estudo da estrutura social. Zahar, Rio de Janeiro.

Mimieux, T. (2007). "The changing nature of wage inequality". National Bureau of Economic Research, Working Paper 13523. Disponível em: http://www.nber.org/papers/w13523

Mouw, T. ; Kalleberg, A; (2010). "Occupations and the structure of wage inequality in the United States, 1980s to 2000s". American Sociological Review. Vol 75.

Moya, M. E. (2003). "Repensando a questão social: trajetórias de algumas interpretações nos Estados Unidos, França e Brasil". Dissertação de Mestrado em Ciência Política. Universidade de São Paulo. 
Myrdal, G. (1963). “Challenge to affluence”. Pantheon Books, New York.

Neri, M. (2011) “A nova classe média”. Editora Saraiva, São Paulo.

Neri, M., Camargo, J. M., Reis, M. C. (2000) "Mercado de trabalho nos anos 90: fatos estilizados e interpretações". Texto para discussão 743, IPEA, Brasília.

Neto, R. M. S. (2010). "Impacto do Programa Bolsa Família sobre a frequência à escola: estimativas a partir da PNAD”. In: Castro ; Abraão, op. cit.

Newman, K. (2006). "Chutes and ladders: navigating the low-wage labor market". Harvard University Press. MA.

Noronha, E. (2003). "Informal, illegal, injusto: percepções do mercado de trabalho no Brasil”. Revista Brasileira de Ciências Sociais. v. 18, nº 53.

Nun, J. L. (2003). "Marginalidad y exclusion social". Fondo de Cultura Económica, Buenos Aires.

O’Connor, J. (1977). "USA: a crise do estado capitalista". Paz e Terra. Rio de Janeiro.

Oesch, D.; Rodriguez Menes, J. (2012). "Upgrading or polarization? Occupational change in Britain, Germany, Spain and Switzerland, 1990-2008". Socio-Economic Review, 9, 503-532.

Offe, C. (1989) "Capitalismo desorganizado: transformações contemporaneas do trabalho e da política". Brasiliense, São Paulo.

Oliveira, F. (2003) “Crítica à razão dualista; o ornitorrinco”. Boitempo, São Paulo.

Oliveira, L. (1997) "Os excluídos existem? notas sobre a elaboração de um novo conceito". Revista Brasileira de Ciências Sociais, v. 12, n. 33, p. 49-61. São Paulo.

Parsons, T. (1951). “The social system". Routledge, London.

(1974) “O sistema das sociedades modernas”. Pioneira, São Paulo.

Pierson, P. (2001) "The new politics of the Welfare State". Oxford University Press, UK.

Paugam, S. (1999). “A abordagem sociológica da exclusão. In: Verás, M. P. Por uma sociologia da exclusão. O debate com Serge Paugam. EDUC, São Paulo.

São Paulo. (2003) “Desqualificação social: ensaio sobre a nova pobreza". Cortez, 
Pochman, M. (2004) "Proteção social na periferia do capitalismo". São Paulo em Perspectiva, vol. 18, n 2. São Paulo.

(2012). “Nova classe média?”. Boitempo, São Paulo.

Polanyi, K. (2000). “A grande transformação. As origens da nossa época”. Elsevier, Rio de Janeiro.

Prates, I.; Barbosa, R. J. (2013). "Mercado de trabalho, estrutura ocupacional e pobreza". In: Marques, E. C. (org): São Paulo nos 2000. No prelo.

Queiroz, L. C. R. (2005). "Segregación residencial y segmentación social: el efecto "vecindário" em la produción de la pobreza en las metrópolis brasileñas". In Lezguizamón, S. A. (2005), op. cit.

Ramalho, R.; Santana , M. A. (2003) “Além da fábrica”. Boitempo, São Paulo.

Reis, F. W. (1991) "O tabelião e a lupa: teoria, método generalizante e idiografia no contexto brasileiro". Revista Brasileira de Ciencias Sociais, ano 6, n 16. São Paulo.

(2000) “Mercado e utopia”. Edusp, São Paulo.

Ribeiro, C. A. (2007) "Estrutura de Classe e Mobilidade Social no Brasil" EDUSC, São Carlos.

Rocha, S. (1998) "Renda e pobreza. Medidas per capita versus adulto-equivalente". Texto para discussão $n^{\circ} 609$, IPEA. Rio de Janeiro.

(2006) "Pobreza e indigência no Brasil - algumas evidências empíricas com base na PNAD 2004”. Revista Nova Economia, Belo Horizonte.

(2009) "Pobreza no Brasil: afinal, do que se trata". FGV, Rio de Janeiro.

Roy, A. (2010). "Poverty capital: microfinance and the making of development". Routledge, Nova York.

Ruggie, J. G. (1982). "International regimes, transactions, and change: Embedded liberalism in the Postwar Economic Order". International Organization, v 36, Issue 2.

Sainsbury, D. (1993). "Gender, equality and the welfare state". Cambridge University Press.

Sainz, J. P. B.; Salas, M. (2006). "Exclusión social, desigualdades y excedente laboral. Reflexiones analíticas sobre America Latina". Revista Mexicana de Sociología. V 68, $n^{\text {o } 3, ~ p . ~ 431-465 . ~ U n i v e r s i d a d ~ N a c i o n a l ~ A u t o n o m a ~ d e ~ M e x i c o . ~ C i u d a d ~ d e ~ M e x i c o . ~}$

Santos, J. A. F. (2004). "Estrutura de posições de classe no Brasil: Mapeamentos, mudanças e efeitos de renda". Argumentvm, Belo Horizonte. 
Santos, W. G. (1979) “Cidadania e justiça”. Editora Campus, Rio de Janeiro.

Sassen, S. (1991). "The global city: New York, London, Tokyo". Princeton University Press.

Scalon, C. (2009). “Ensaios de estratificação". Argumentvm. Belo Horizonte.

Schneider, B. R. (2009). "Hierarchical Market Economies and Varieties of Capitalism in Latin America". Journal of Latin America Studies. v. 41.

Sharpf F. ; Schimidt, V. (2000) "Work and welfare". Oxford University Press, NY.

Schwartzman, S.; Brock, C. (2005) "Os desafios da educação no Brasil". Nova Fronteira. Rio de Janeiro.

Silver, H. (1994). "Exclusión social y solidaridad social: tres paradigmas". Revista Internacional Del Trabajo 113.

Singer, A. (2012). "Os sentidos do lulismo. Reforma gradual e pacto conservador". Companhia das Letras. São Paulo.

Small, M., Newman, K. (2001) "Urban poverty after the Truly Disadvantaged: the rediscovery of the family, the neigborhood and culture. Annual Review of Sociology. 27, p. $23-45$.

Soares, S.; Satyro, N. (2009). “Análise do impacto do programa bolsa família e do benefício de prestação continuada na redução da desigualdade nos estados brasileiros 2004 a 2006". Texto para discussão n 1435, IPEA Rio de Janeiro.

Souza, J. (2012). "Os trabalhadores brasileiros: nova classe média ou nova classe trabalhadora". Editora UFMG. Belo Horizonte.

Suárez, M.; Libardoni, M. (2007). "O Impacto do Programa Bolsa Família: mudanças e continuidades na condição social das mulheres". In: Vaitsman, J.; Paes-Souza, R. (orgs). Avaliação de Políticas e Programas do MDS. Ministério do Desenvolvimento Social e Combate à Fome. BRASÍLIA.

Swenson, P. (2002) “Capitalists against market”. Oxford University Press, UK.

Teixeira, C. (2008). "Análise do impacto do Programa Bolsa Família na oferta de trabalho dos homens e mulheres" In: Castro; J. A. Modesto, L. (2010), op. cit.

Telles, V. S. (2001) “Pobreza e cidadania”. Editora 34, São Paulo.

Telles, V. S.; Cabannes, R. (2006) "Nas tramas da cidade: trajetórias urbanas e seus territórios”. Humanitas, São Paulo.

Titmuss, R. (1959). “Essays on the welfare state”. Yale University Press. 
Vaattovaara, M.; Kortteinen, M. (2003). "Beyond polarization versus professionalization? A case study of the development of the Hensinki region, Finland". Urban Studies. v 40.

Vaitsman, J., Paes-Souza, R. (2007) “Avaliação de Políticas e Programas do MDS". BRASÍLIA: MDS.

Valladares, L. (1991) “Cem anos pensando a pobreza (urbana) no Brasil”, In Boschi, R. R., “Corporativismo e desigualdade". Editora Ipuerj, Rio de Janeiro.

Verás, M. P. (2003) “Prefácio à edição brasileira”. In: Paugam, S. op.cit.

Viana, L. W. (1978) "Liberalismo e sindicalismo no Brasil". Estudos Brasileiros, Rio de Janeiro.

Yazbek, M. C. (2009) "Estado e políticas sociais" Praia Vermelha, v. 18, nº 1 , Rio de Janeiro.

Wilson, W. J. (1986). "The truly disadvantaged: The inner city, the underclass and public policy". Chicago University Press. Chicago.

(1996). "When work disappear: the world of new urban poor".

Vintage Books. Nova York.

Wacquant, L. (2001). "Os condenados da cidade". Revan, Rio de Janeiro.

Weber, M; Gerth, H; Mills, C. W. (1982) "Ensaios de sociologia". Zahar Editores, Rio de Janeiro.

Willnesky, H. (1975). “The welfare state and equity". California University Press. CA.

Wright, E. O.; Dwyer, R. (2003) "The Patterns of Job Expansions in the United States: A Comparison of the 1960s and 1990s," Socio-Economic Review 1, 289-325.

Ziccardi, A. (2008) "Procesos de urbanización de la pobreza y nuevas formas de exclusión social”. Siglo del Hombre Editores, Clacso-Crop. Bogotá. 
ANEXO METODOLÓGICO 


\section{ANEXO METODOLÓGICO}

Este anexo tem dois objetivos. Em primeiro lugar, visa esclarecer alguns pontos relativos à metodologia empregada quando do tratamento dos dados, ressaltando os motivos que nos levaram a adotar um único banco para os três anos (1991, 2000 e 2010), para daí efetuarmos os cálculos dos quintis de ocupação e as análises subsequentes. Em segundo, apresenta um segundo exercício empírico, alternativo àquele que está apresentado no corpo do texto, de modo a demonstrar que não haveriam diferenças nos resultados a que $\mathrm{s}$ chegamos se procedimento distinto houvesse sido realizado. $^{57}$

a) Sobre a compatibilização das ocupações nos Censos Demográficos de 1991, 2000 e 2010

Um primeiro ponto a se ressaltar é que, tomando apenas a Região Metropolitana de São Paulo, o número de códigos ocupacionais da Classificação Brasileira de Ocupações (CBO) é distinto nos três anos dos censos demográficos analisados. Apenas do ponto de vista quantitativo, notamos que: no ano de 1991, contabilizamos um total de 378 ocupações; em 2000, 502; e em 2010, 432.

Estas distinções colocaram a impossibilidade de, já no ponto de partida, fixarmos um "ano base" de classificação para que posteriormente os códigos dos dois outros anos fossem reduzidos aos códigos similares existentes no ano base escolhido. Por exemplo, se tomássemos o ano de 1991 como este "ano base" fictício, ficaríamos impossibilitados de traduzir 124 códigos do ano de 2000 e 54 códigos do ano de 2010.

Desta forma, optamos por traduzir os códigos ocupacionais dos três anos em um mesmo denominador comum, bastante utilizado na literatura especializada, qual seja, a classificação internacional padronizada ISCO-88, 4 dígitos. A fim de reduzir o número excessivo de códigos e o grau de detalhamento de ocupações de 4 dígitos, reduzimos a classificação ISCO-88 a 3 dígitos, nos três anos.

\footnotetext{
${ }^{57}$ Agradeço os comentários e sugestões do Prof. Adalberto Cardoso, membro da banca examinadora da dissertação, os quais me animaram a incluir este Anexo e esta fonte suplementar de demonstração da solidez da demonstração empírica constante do corpo do texto.
} 
No entanto, como entender a dinâmica dos setores de atividade econômica era igualmente relevante para o argumento que vínhamos desenvolvendo, optamos, ainda seguindo o modelo de Wright e Dwyer (2003), por especificar ocupações no interior de cada setor de atividade. A principal justificativa aqui é a de que ocupações que assumiam o mesmo código poderiam ter significados distintos se observássemos que as atividades eram realizadas em diferentes setores da economia.

O resultado preliminar desse exercício foi a criação de uma nova codificação para as ocupações que resultava do cruzamento do código ISCO-88 (3 dígitos) com o código dos setores de atividade econômica ISIC (1 dígito). Foram criados, assim, 528 códigos de "ocupação-setor" para o ano de 1991, 485 para o ano de 2000 e 556 para o ano de 2010.

O que esse resultado deixa entrever é que, mesmo quando utilizamos códigos ocupacionais e setoriais de atividade comuns a cada um dos anos, os números de ocupações-setor são distintos em 1991, 2000 e 2010, o que evidencia, do ponto de vista empírico, a existência de alterações na estrutura ocupacional. Dessa forma, como lidar com essas alterações que, como dito, ultrapassam a simples questão classificatória das ocupações?

Novamente, fixar um "ano base" nos impossibilitaria documentar a mudança ocorrida, visto que reduziríamos as ocupações ao cenário de um único ano, minimizando as alterações ocorridas na estrutura ocupacional. Assim fazendo, acabaríamos por obscurecer as transformações no nosso objeto de interesse analítico. Ademais, sendo distintos os números absolutos de ocupações em cada um dos anos, os quintis que fossem fixados no ano base determinado deixariam de ser "quintis" quando da classificação das ocupações nos anos seguintes.

Vejamos, por exemplo, se trabalhássemos com quintis de ocupação tendo por base o ano de 1991. Cada quintil comportava, em 1991, um total aproximado de 105 ocupações, que é igual ao total de ocupações em 1991 (528) dividido por 5, hierarquizados segundo a mediana do rendimento no interior da ocupação setor. Como em 2000 tínhamos apenas 485 códigos de ocupação setor, alguns quintis ficariam esvaziados, ao passo que outros poderiam ficar inflados, de modo que, no melhor das hipóteses, teríamos 97 ocupações em cada quintil. No ano de 2010, o problema seria 
semelhante: alguns códigos de ocupação setor não existentes no ano de 1991 teriam que ser "introduzidos" no interior dos quintis (cada quintil teria, aproximadamente, 111 ocupações). Em suma, na medida em que o número de ocupações-setor não é o mesmo em todos anos, os quintis também serão distintos em termos absolutos do número de ocupações e não seriam, portanto, comparáveis.

Isso nos levou a buscar uma solução que tornasse essa comparação viável. O único modo de alcançar tal objetivo foi a criação de um banco de dados que reunisse os três anos analisados. Tal procedimento deu-se de acordo com os passos seguintes:

1) Criamos, como dito acima, os códigos de ocupação-setor para cada um dos anos (1991, 2000 e 2010) a partir do cruzamento dos códigos "ISCO - 3 dígitos" e "ISIC - I dígito".

2) Fundimos, num único banco de dados, todos os indivíduos ocupados nos anos analisados, tendo cada um dos indivíduos um código de ocupação-setor correspondente à ocupação exercida no ano em questão.

3) Hierarquizamos as ocupações a partir da mediana do rendimento da ocupaçãosetor.

4) Construímos os quintis a partir do número absoluto de pessoas no interior de cada uma das ocupações.

5) Classificamos cada ocupação-setor em cada um dos quintis corresponde a esta hierarquização.

A classificação dos quintis que resultou desse procedimento de fusão dos três bancos espelha a média do período. É como se toda a estrutura do mercado de trabalho da RMSP nos anos de 1991, 2000 e 2010 fosse unificada num único ponto do tempo. Isto quer dizer que as transformações analisadas para cada uma das décadas (1991-2000 e 2000-2010) evidenciam, antes de tudo, tendências a partir desse cenário, ou seja, a partir da média do período.

É certo que as transformações analisadas a partir desta "média" - que representa um cenário hipotético, criado artificialmente - em alguma medida, também acabam por minimizar a apreensão do total das transformações que realmente ocorreram. Entretanto, 
se não houvéssemos realizado tal procedimento, ficaríamos reféns das variações nos critérios de classificação, por um lado, e da própria impossibilidade de criar denominadores comuns que espelhassem as transformações, por outro.

A escolha metodológica, nesse caso, foi entre: i) reduzir em alguma medida a capacidade de apreensão da intensidade das mudanças, priorizando a comparabilidade a partir das tendências gerais das décadas tendo como ponto de referencia a média do período; ou ii) reduzir a diversidade do período a uma estrutura dada em um ponto do tempo, o que reduziria a apreensão da mudança (porque a estrutura ocupacional estaria "congelada" em um único ponto) e, por conseguinte, implicaria num grau de comparabilidade ainda mais reduzido, justamente porque desprezaria as transformações ocupacionais do total do período analisado.

Optamos pela primeira alternativa por acreditarmos que ela nos assegurava a comparabilidade necessária para captar as tendências gerais das mudanças entre as décadas, mesmo se captando-as apenas parcialmente porque apenas a partir da "média" do período.

Assim, a solução metodológica adotada permitiu contornar um problema técnico o qual, mais que um simples limite classificatório, é (ele mesmo) um indicador do modo como as classificações ocupacionais tentam se adaptar às importantes transformações na estrutura ocupacional que estavam em curso.

\section{b) Exercício contrafactual}

Entretanto, para argumentar em favor da solidez da demonstração empírica que apresentamos no corpo da dissertação, convém agregar um outro passo. Este é o papel do exercício que a seguir desenvolvemos.

Poder-se-ia argumentar que, ao classificarmos os quintis segundo o número de ocupados no interior das ocupações, e não em quintis de ocupações propriamente ditos, o resultado espelharia, antes de tudo, um efeito de agregação de pessoas no interior de ocupações-quintis, antes que um efeito de efetiva mudança na estrutura das ocupações, o que reduziria a capacidade de apreensão das mudanças nesta ultima dimensão, objeto do interesse deste trabalho. 
Para fazer face a tal argumento, realizamos um exercício contrafactual onde hierarquizamos as ocupações a partir da mediana da renda, e não a partir dos indivíduos nelas agrupados. Ou seja, tratam-se de quintis de ocupações.

O painel de gráficos abaixo confronta (i) os resultados originais (que podem ser igualmente encontrados na página 101), os quais estão agora reproduzidos no lado esquerdo da figura abaixo, (ii) com os resultados do exercício contrafactual, que são apresentados no lado direito do painel de gráficos.

Gráfico 24 - Evolução da estrutura ocupacional; 1991-2000 e 2000-2010: Exercícios originais e contrafactuais
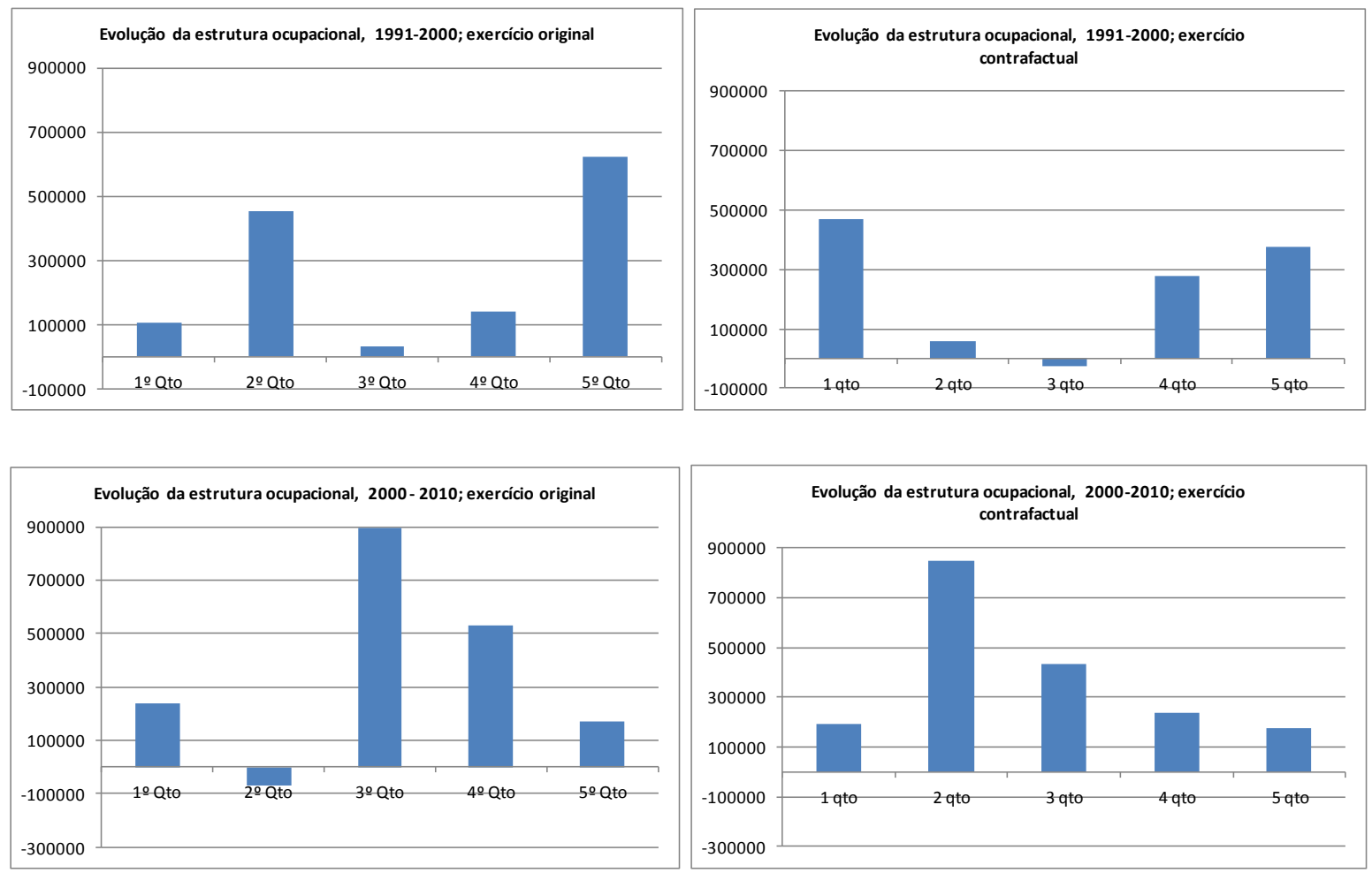

Fonte: Microdados dos Censos Demográficos (IBGE), 1991, 2000 e 2010

Como era de se esperar, os resultados são distintos, em virtude da forma como as ocupações foram hierarquizadas para a construção dos quintis. No primeiro caso, os quintis foram construídos a partir do percentual de pessoas em ocupações até determinado nível de mediana da renda no interior de cada ocupação. Por exemplo, no primeiro quintil, estavam todas pessoas que se encontravam em ocupações cuja mediana tinha como teto os primeiros $20,0 \%$ inferiores da distribuição, e assim por diante. Um resultado óbvio desse procedimento é que os quintis inferiores contém, 
necessariamente, menos ocupações do que os quintis superiores, justamente porque as ocupações de base tendem a ser mais numerosas. No segundo caso, as ocupações foram hierarquizadas unicamente a partir do seu rendimento mediano, independentemente de quantas pessoas comportavam.

Do ponto de vista de um exercício contrafactual o importante, contudo, é observar que os resultados, apesar de distintos no que concerne ao saldo dos quintis nos dois exercicios, são semelhantes do ponto de vista das tendências observadas em ambas as décadas. Assim, os resultados são claros ao mostrar que a década de 1990 foi marcada por um processo de polarização da estrutura ocupacional, ao passo que a década de 2000 manifesta uma atenuação desse processo.

Em suma, os resultados do exercício contrafactual reiteram as interpretações construídas a partir do exercício original no capitulo terceiro, corroborando, assim, as conclusões e o dialogo travado com a literatura especializada. 